\title{
Host monitoring of quorum sensing during Pseudomonas aeruginosa infection
}

Authors: Pedro Moura-Alves ${ }^{1,2^{*}}$, Andreas Puyskens ${ }^{1}$, Anne Stinn ${ }^{1,3,4,5}$, Marion Klemm ${ }^{1}$, Ute Guhlich-Bornhof ${ }^{1}$, Anca Dorhoi ${ }^{1,6,7}$, Jens Furkert ${ }^{8}$, Annika Kreuchwig ${ }^{8}$, Jonas Protze ${ }^{8}$, Laura Lozza $^{1,9}$, Gang Pei ${ }^{1}$, Philippe Saikali ${ }^{1}$, Carolina Perdomo ${ }^{1}$, Hans J. Mollenkopf ${ }^{10}$, Robert Hurwitz $^{11}$, Frank Kirschhoefer ${ }^{12}$, Gerald Brenner-Weiss ${ }^{11}$, January Weiner $3^{\text {rd1 }}$, Hartmut Oschkinat $^{8}$, Michael Kolbe ${ }^{3,4,5}$, Gerd Krause ${ }^{8}$, Stefan H.E. Kaufmann ${ }^{1,13^{*}}$

\section{Affiliations:}

${ }^{1}$ Max Planck Institute for Infection Biology, Department of Immunology, Charitéplatz 1, 10117 Berlin, Germany.

${ }^{2}$ Nuffield Department of Clinical Medicine, Ludwig Institute for Cancer Research, University of Oxford, Oxford, UK.

${ }^{3}$ Max Planck Institute for Infection Biology, Structural Systems Biology, Charitéplatz 1, 10117 Berlin, Germany.

${ }^{4}$ Department of Structural Infection Biology, Centre for Structural Systems Biology (CSSB), Helmholtz-Centre for Infection Research (HZI), Notkestraße 85, 22607 Hamburg, Germany. ${ }^{5}$ Faculty of Mathematics, Informatics and Natural Sciences, University of Hamburg, Rothenbaumchaussee 19, 20148 Hamburg, Germany.

${ }^{6}$ Institute of Immunology, Friedrich-Loeffler Institut, Greifswald - Insel Riems, Germany.

${ }^{7}$ Faculty of Mathematics and Natural Sciences, University of Greifswald, Greifswald, Germany.

${ }^{8}$ Leibniz-Forschungsinstitut für Molekulare Pharmakologie (FMP), Robert-Rössle-Strasse 10, 13125 Berlin, Germany.

${ }^{9}$ Epiontis GmbH - Precision for Medicine, Barbara-McClintock- Str. 6, 12489 Berlin, Germany.

${ }^{10}$ Microarray Core Facility, Max Planck Institute for Infection Biology, Department of Immunology, Charitéplatz 1, 10117 Berlin, Germany. 
$29{ }^{11}$ Protein Purification Core Facility, Max Planck Institute for Infection Biology, Charitéplatz $30 \quad 1,10117$ Berlin, Germany.

$31{ }^{12}$ Institute of Functional Interfaces, Karlsruhe Institute of Technology, Karlsruhe, Germany.

$32 \quad{ }^{13}$ Hagler Institute for Advanced Study at Texas A\&M University, College Station, TX 7843.

*Correspondence to: pedro.mouraalves@ludwig.ox.ac.uk ; kaufmann@mpiib-berlin.mpg.de 
DIAAAS

Abstract: Pseudomonas aeruginosa (P.aeruginosa) rapidly adapts to altered conditions by quorum sensing (QS), a communication system used to collectively modify its behaviour, via production, release and detection of signalling molecules. QS molecules can also be sensed by hosts, however respective receptors and signalling pathways are poorly understood. We describe a unique pattern of regulation in the host by the Aryl hydrocarbon Receptor (AhR), critically dependent on qualitative and quantitative sensing of P.aeruginosa quorum. QS molecules bind to the AhR and distinctly modulate its activity. This is mirrored upon infection with P.aeruginosa collected from diverse growth stages and with QS-mutants. We propose that by spying on bacterial quorum, the AhR is a major sensor of infection dynamics, capable of orchestrating host defence according to the status quo of infection.

One Sentence Summary: By sensing bacterial communication the Aryl hydrocarbon Receptor modulates host defence according to the level of threat.

\section{Main Text:}

Pseudomonas aeruginosa (P.aeruginosa) is a resourceful and ubiquitous gramnegative bacterium that causes infectious diseases in a broad spectrum of organisms, including plants, animals and humans( $(1)$. Its prevalence in burn victims, Cystic Fibrosis (CF) patients and immunocompromised individuals, such as AIDS patients, is commonly associated with a poor, often fatal outcome(2). P.aeruginosa is also a major cause of nosocomial infections, such as bacterial pneumonia, urinary tract infection and surgical-wound contamination(1). Because of its profound antibiotic resistance, therapy of P.aeruginosa is extremely difficult( 1 ). Moreover, this pathogen possesses a wide range of mechanisms to adapt to different and sometimes harsh environments, further aggravating its eradication, even by antibiotic treatment $(1)$. One such important and unifying mechanism is the capacity of P.aeruginosa to perform quorum sensing (QS)(1, 3, 4). QS is a cell-to-cell signalling mechanism employed by different bacteria to coordinate their activities in response to changes in community density, via chemical communication using different diffusible molecules, so called autoinducers (AI), and their receptors (Fig.1A)(3, 4). In P.aeruginosa, QS regulates production of a vast set of virulence factors, such as extracellular proteases and phenazines, and is crucial for colonization and infection, regulating diverse mechanisms such as biofilm formation and antimicrobial resistance(1, 3-5). Differences in P.aeruginosa virulence and transition from acute to chronic infection have been linked to changes in autoinducer levels, as well as in the expression of QS 
regulated genes $(1,3,6-8)$. Consequently, QS constitutes an obvious target in the current search for novel treatment options for P.aeruginosa infections(3, 4, 9). Noteworthy, changes in expression of AI, and QS regulated genes, may not only impact on bacterial community dynamics, but also on the host response during infection. It has been previously reported that different QS regulated molecules, such as homoserine lactones (HSL), quinolones and phenazines, can interact with host cells, influencing a broad range of responses, including immunomodulation(9). Thus far, the host receptors and signalling pathways, as well as the mechanisms involved in monitoring infection dynamics are incompletely understood.

Recently, we have demonstrated that the Aryl Hydrocarbon Receptor (AhR), a highly conserved ligand dependent transcription factor, directly recognizes P.aeruginosa phenazines, and thereby plays an important role in infection control(10). AhR binds to phenazines, mediates their degradation and regulates the expression of several host genes including detoxifying enzymes, chemokines and cytokines. Accordingly, resistance of $\mathrm{AhR}$ deficient $\left(A h R^{-/-}\right)$mice to P.aeruginosa is diminished(10). Taking into consideration the vast set of ligands that the AhR is able to detect and the numerous biological roles it can exert, we hypothesized that AhR monitors the course of bacterial infection and disease by sensing different bacterial QS molecules expressed at various stages of infection (Fig.1A), and thereby orchestrates the most appropriate immune response against different stages of infection.

\section{Results}

\section{AhR senses bacterial QS molecules in vitro}

Using luciferase AhR reporter cells(10), we infected THP-1 macrophages (THP-1 AhR reporter) and A549 alveolar type II pneumocytes (A549 AhR reporter) with P.aeruginosa laboratory wild type (WT) UCBPP-PA14 (PA14 WT) and GFP labelled (PA14 WT-GFP) strains collected from distinct stages of bacterial growth (early log: OD600<0.3; mid log: $0.5<0 D 600<0.8$; late log: OD600>1). AhR was more profoundly activated by bacteria from later growth phases (Fig.1B and Fig.S1A), while multiplicity of infection (MOI, Fig.S1B) and percentage of infected cells remained comparable over the different growth stages (Fig.S1C,D).Similar results were obtained with filtered bacterial supernatants from PA14-WT strains (Fig.1C and Fig.S1E), pointing to different AhR signalling by distinct P.aeruginosa molecules. A comparable phenotype was observed using supernatants from PAO1, a different commonly used P.aeruginosa laboratory strain (Fig.S1F). Amongst the obvious candidates are 
101 the P.aeruginosa phenazines, previously identified as AhR ligands (10). Consistently, increasing concentrations of the P.aeruginosa phenazine pyocyanin (Pyo) were detected in PA14 supernatants along bacterial growth (Fig.S1G, H), correlating with the observed AhR activation (Fig.1B,C and Fig.S1A,E).

Phenazines are part of the QS regulated molecules expressed by P.aeruginosa, with Pyo providing a terminal signal of $\mathrm{QS}(3,4,11,12)$. P.aeruginosa $\mathrm{QS}$ is regulated by four tightly controlled pathways, namely Las, Rhl, Pqs and Iqs (Fig.1A)(3, 4, 12). These pathways are tightly interconnected and their cognate autoinducer molecules are capable of activating a distinct downstream transcriptional pathway (Fig.1A). In brief, N-3-oxo-dodecanoylhomoserine lactone (3-o-C12-L-HSL) and N-butanoyl-homoserine lactone (C4-L-HSL) are produced in a sequential manner via Las and Rhl systems, and activate the receptors LasR and RhlR, respectively $(3,4,12)$. A third pathway, Pqs, leads to the synthesis of the Pseudomonas quinolone signalling molecule (2-heptyl-3-hydroxy-4-quinolone, PQS), and its precursor 4hydroxy-2-heptylquinoline (HHQ), which signal via the $\operatorname{PqsR}(3,4,12)$. Recently, the Iqs pathway has been discovered, however the mechanism of 2-(2-hydroxyphenyl)-thiazole-4carbaldehyde (IQS) production and its receptor are less understood(1, 3). Using highperformance liquid chromatography (HPLC), we confirmed a sequential autoinducer abundance in the supernatants of PA14 (Fig.1D). Considering the unique expression profiles of the QS molecules 3-o-C12-L-HSL, C4-L-HSL, HHQ and PQS, we determined their ability to modulate canonical AhR signalling. Stimulation of THP-1 and A549 AhR reporter cells with the different P.aeruginosa QS molecules resulted in differential modulation of AhR signalling (Fig.1E). The 3-o-C12-L-HSL and HHQ potently inhibited AhR activation by the known Pseudomonas AhR ligand 1-hydroxyphenazine (1-HP)(10), in a dose dependent manner (Fig.1F,G). Several QS molecules have been reported to induce apoptosis in host cells, depending on the concentration, cell type and exposure time $(13,14)$. No major differences in cell viability were detected for the majority of the conditions tested here, as measured by lactate dehydrogenase (LDH) release (Fig.S2A). An exception occurred after $24 \mathrm{~h}$ stimulation of THP1 cells with high concentrations of 3-o-C12-L-HSL (Fig.S2A). These results are in agreement with previous studies showing that epithelial cells, such as A549, are more resistant to 3-0C12-L-HSL induced apoptosis than macrophages $(13,14)$. All experiments with THP-1 cells in the presence of 3-o-C12-L-HSL were performed at earlier time points, when no differences in cell viability were detected. Yet, we decided to further exclude a possible relationship between 
apoptosis related effects and AhR modulation in this cell type. As shown in Fig.S2B-E, no relationship was observed and we decided to focus on A549 cells in following experiments.

Previous studies unveiled that concentrations of QS molecules in P.aeruginosa, such as 3-o-C12-L-HSL, can vary profoundly. These include the growth status, type of cultures (planktonic cultures $(1-5 \mu \mathrm{M}$ ) or biofilms (up to $600 \mu \mathrm{M}$ )) and sample type (sputum or murine infection samples)(15-18). Notably, high concentrations of these molecules have been detected in biofilms of CF patients' lungs, and thus in close contact with the epithelium(18). Consequently, we decided to use $50 \mu \mathrm{M}$ of the different QS molecules in subsequent studies.

A hallmark of AhR activity is the transcriptional induction of detoxifying enzymes, such as CYPlAl and CYPlBl, and of the AhR repressor $(A h R R)(19)$. As previously reported(10), stimulation of A549 cells with 1-HP induces mRNA expression of these genes (Fig.1H and Fig.S3A). Intriguingly, 3-o-C12-L-HSL and HHQ inhibited 1-HP induced gene expression (Fig.2F and Fig.S3A). Due to its involvement in tryptophan metabolism, alterations in CYP1A1 expression and activity can influence AhR activation $(20,21)$. We took advantage of an established model using mouse liver cells (Hepa-1c1c7), which due to the expression of copious levels of CYP1A1 is best suited to detect its expression and enzymatic activity(22). Similar to other cell types, AhR activation in hepatocytes was induced by 1-HP, as measured by increased luciferase activity in an AhR reporter cell line and increased CYP1A1 enzymatic activity, measured by the EROD assay (Fig.1I and Fig.S3B, C). Intriguingly, 3-o-C12-L-HSL, HHQ and PQS, inhibited 1-HP induced AhR activation and CYP1A1 enzymatic activity in these cells, whereas C4-L-HSL did not (Fig.1J and Fig. S3B, C). In sum, QS molecules, including HSLs, quinolones and phenazines, modulated AhR activity in both a stimulatory and an inhibitory direction.

QS molecules are not only expressed by P.aeruginosa; several other gram-negative bacteria also produce HSLs, with subtle modifications, mostly in the carbon side chain $(3,4)$ (Table S1). Since the crystal structure of the AhR has not yet been solved, it is challenging to predict ligands that bind to AhR. Taking advantage of the AhR modulatory properties of a vast number of HSLs and their tested analogues (Fig.S4A-C), we optimized an existing in silico model(10) to interrogate whether and how these QS molecules from P.aeruginosa can be accommodated in the AhR binding pocket (Fig.2A). The ligands were divided by impact on agonistic or competitive behaviour and sorted with increasing MM-GBSA binding energies $\left(\Delta \mathrm{G}^{\mathrm{Bind}}\right)$, revealing 3-o-C12-L-HSL as the strongest binder and C4-L-HSL as the weakest binder in this study (Fig.S4D). In this model, all residues previously found to interact with 
TCDD by mutagenesis experiments $(23,24)$, are predicted to be involved in forming the binding pocket. The key residues, Thr289, His291, Phe295, Ser365 and Gln383, form hydrogen bonds with most of the ligands investigated here (Fig.S4D, E). Furthermore, and in agreement with data retrieved from ligand-selective modulation of AhR ligand binding, AhR complexes with bound competitors showed additional hydrophobic interactions with Phe287, Leu308 and Leu315 (Fig.S4D,E)(25). 1-HP is predicted to contact Phe324 via interactions of the aromatic rings (Fig.S4E). This residue is known to mediate agonist/antagonist switching upon mutation (Phe324Ala/Leu) and converts agonists such as 3MC or BNF into antagonists(25). Predictions were validated by ligand-binding studies (10), confirming the binding of 3-o-C12-L-HSL and HHQ, with dissociation constant $\left(\mathrm{K}_{\mathrm{d}}\right)$ values of $4.67 \mu \mathrm{M}$ or $3.77 \mu \mathrm{M}$, respectively (Fig.2B and Fig.S4F). In addition, we developed a complementary method to detect AhR binding of different ligands, including the bona fide AhR ligand 2,3,7,8-tetrachlorodibenzodioxin (TCDD)(26), using purified AhR and ARNT proteins in a Microscale thermophoresis (MST) assay (Fig.S4G). This approach also demonstrated AhR binding to QS molecules, including 3o-C12-L-HSL, PQS and 1-HP, but not to C4-L-HSL (Fig.2C). Of note, HHQ binding could not be analysed by MST due to its intrinsic fluorescence properties, which interfere with the assay. Altogether, various QS molecules, other than phenazines, bind to AhR and modulate its activity, endorsing this pathway as potential target for sensing bacterial infection dynamics in the host.

AhR QS ligand interactions were further defined using an A549 AhR CRISPR KO cell line (Fig.3A and Fig.S5A). Induction of AhR dependent genes was detected upon 1-HP stimulation of CRISPR Scramble control, and absent in the AhR-KO cells (Fig.S5B). In contrast, and as previously shown in WT A549 cells, 3-o-C12-L-HSL and HHQ caused AhR inhibition (Fig.S5B,C). Major functions of AhR include xenobiotic metabolism, toxin degradation and excretion(26). Previously, we demonstrated that AhR mediates the degradation of bacterial molecules, such as P.aeruginosa phenazines and Mycobacterium tuberculosis naphthoquinone phthiocol(10). Using an established P.aeruginosa 3-o-C12-LHSL luminescence reporter strain (PA14-R3)(27) to detect 3-o-C12-L-HSL levels (Fig.S5D), we evaluated its degradation profile upon exposure to AhR proficient and deficient cells (Fig.S5E). Bioluminescence emitted by the bacterial reporter cells decreased in a time dependent manner, indicating reduced abundance of 3-o-C12-L-HSL (Fig.3B). In contrast, no differences were detected between Scramble control and AhR-KO cells (Fig.3B). These results were confirmed by HPLC (Fig.3C). A similar approach was used to determine the metabolism 
of HHQ (Fig.S5E), using the PAO1 pqsA CTX-lux::pqsA reporter strain (Fig.S5F)(28) and by HPLC. Surprisingly, no degradation of HHQ was observed by any of the methods when exposing cells to $50 \mu \mathrm{M}$ of HHQ (Fig.S5G,H). However, exposing cells to a lower concentration of HHQ $(0.5 \mu \mathrm{M})$, diminished levels of HHQ were detected at late time points, although no differences between AhR proficient and AhR deficient cells were observed (Fig.3D). Altogether, under the conditions tested, our results argue against an involvement of AhR in the degradation of P.aeruginosa 3-o-C12-L-HSL or HHQ. In addition to its role in xenobiotic metabolism, AhR participates in the regulation of different immune mediators(10, 19, 26, 29). Accordingly, we evaluated whether upon exposure to different QS molecules, AhR regulates cytokine and chemokine expression. Different bacterial ligands induced different gene expression patterns (Fig.3E, F). It has been previously reported that infection with P.aeruginosa, or exposure to 3-o-C12-L-HSL, leads to $I L-6$ and $I L-8$ expression(30, 31). Consistently, amongst the genes induced by $3-0-C 12-L-H S L, I L-6$ and $I L-8$ were highly induced in the AhR-KO cells, as compared to Scramble control. Elevated induction of IL-8 was also observed upon exposure of AhR-KO cells to HHQ, whilst 1-HP stimulation led to reduced induction. A similar profile was observed for $C X C L 1, C X C L 2$ and $C X C L 3$ (Fig.3E, F). These results emphasize differential AhR modulation of host responses, where sensing the different levels of QS molecules expressed along the infection process can differentially regulate the composition of multiple cytokines and chemokines. Thus, sensing of QS molecules by AhR shapes immunity to infection.

\section{AhR senses bacterial QS molecules in vivo}

As aforementioned, the AhR is conserved between different species (including human, mouse and zebrafish) and few amino acid positions differ in the ligand binding site of AhR proteins (Fig.S6A). However, subtle amino acid differences have been reported to impact binding to specific ligands(26). For example, the human V381, corresponding to A in mouse and zebrafish, is implicated in species related differences regarding the binding affinity to $\operatorname{TCDD}(26,32)$. The mouse AhR has higher binding affinity to TCDD, as compared to the human $\operatorname{AhR}(26,32)$. Consistently, using our in silico modeling, higher TCDD binding affinities of mouse and zebrafish AhR were detected, when compared to the human AhR (Fig. 
S6B). A similar approach was chosen for the P.aeruginosa QS molecules, and MM-GBSA $\Delta G^{\text {Bind }}$ values were calculated starting from the same ligand pose as obtained for the human AhR (Fig.S6C). Strikingly, no species specific differences were predicted to occur, further pointing to a conserved mechanism of sensing of P.aeruginosa infection.

The zebrafish (Danio rerio) has become a powerful model in developmental biology and genetics, and more recently, in toxicology and immunology(33-36). The AhR pathway is conserved in zebrafish and has been shown to be also involved in xenobiotic metabolism(36). Due to genome-wide duplication events, teleosts express various co-orthologues of mammalian genes, though not all are functional. Zebrafish express three AhR isoforms (ahrla, ahrlb and $a h r 2$ ), and the AhR2 is the primary isoform for recognition of toxic ligands, such as TCDD (36). Upon ligand activation, AhR2 drives the expression of hallmark genes, such as cypla, ahhra and ahrrb(36).

It has been previously reported that static immersion of zebrafish larvae in a bacterial suspension, including P.aeruginosa, increases cypla expression(37, 38). Similar results were obtained from microarray analysis of 2 days post fertilization (dpf) larvae infected with PA14WT for 5h or 24h (Fig.S7A and Table S2, S3). Moreover, in addition to cypla, increased expression of additional AhR related genes was observed, such as ahrra and cyplc1(36). Therefore, we evaluated whether we could recapitulate our in vitro findings using this in vivo model organism. Here, 5h exposure of 2 dpf larvae to PA14 WT collected from different phases of bacterial growth with distinct expression patterns of QS molecules (e.g. 3-o-C12-L-HSL and Pyo, Fig.4A), resulted in distinct AhR activation, as measured by cypla mRNA expression (Fig.4B). To mimic the course of infection, bacteria were collected from different growth phases, washed and further resuspended in E3 medium to a final OD similar to the point of collection (i.e. Early $\log -\mathrm{OD} 600=0.2$; Mid $\log -\mathrm{OD} 600=0.7$; Late $\log -\mathrm{OD} 600=1$ ). Exposure of larvae to these bacterial suspensions led to increasing cypla expression along the growth phase (Fig.4B). Still, this could be the result of higher expression of QS molecules and/or increasing bacterial density. To exclude the latter option, we exposed zebrafish larvae to bacterial supernatants after filtration and dilution in E3 medium (1:25 ratio), or to similar bacterial numbers collected from the different growth stages. Exposure of $2 \mathrm{dpf}$ larvae to filtered supernatants or to infection by immersion resulted in elevated cypla expression towards late stages of bacterial growth (Fig.4C, D). These results are in agreement with our in vitro findings (Fig.1B, C and Fig.S1A,E) confirming that P.aeruginosa molecules expressed during diverse growth phases modulate AhR differentially. 
Next, we verified in the zebrafish model our in vitro findings that P.aeruginosa expresses QS molecules, which either activate or inhibit the canonical AhR pathway. We have previously demonstrated that P.aeruginosa phenazines (e.g. 1-HP) activate the AhR pathway in human and mouse(10). Here, exposure of zebrafish larvae $2 \mathrm{dpf}$ to TCDD induced the expression of AhR dependent genes(36) (Fig.S7B). AhR dependency was confirmed by reduced gene expression in the presence of the AhR inhibitor CH223191(39)(Fig.S7B, C). Similarly, we observed AhR modulation upon exposure to the P.aeruginosa phenazine 1-HP, at the transcriptional level (Fig.4E), and Cypla protein expression in response to 1-HP (Fig.4F). To determine whether increased Cyp1a expression translates into enhanced enzymatic activity, we measured its activity in vivo in a semi-high throughput assay (Fig.S7D, E). An increment in fluorescence, as readout of increased Cypla enzymatic activity was detected upon exposure to 1-HP or TCDD, and inhibited by CH223191 (Fig.4G and Fig.S7E, F). AhR was the major sensor of P.aeruginosa phenazines in vivo because microarray analysis of larvae exposed to 1$\mathrm{HP}$, in the presence or absence of the AhR inhibitor revealed that AhR dependent genes(36) were amongst the top10 1-HP induced genes, and their induction was reverted by the CH223191 inhibitor (Fig.4H,I, Fig.S7G and Table S4). Not all of the differentially 1-HP induced genes had been previously shown to be transcriptionally regulated by AhR in the zebrafish. Therefore, we performed an in silico analysis to identify xenobiotic responsive elements (XRE) in their promotor regions(40). We identified putative XREs in the promoter regions of all evaluated genes (Fig.S7H).

Given that our in vitro studies demonstrated that P.aeruginosa also expresses QS molecules that inhibit the AhR pathway, we exposed larvae in vivo to 3-o-C12-L-HSL or HHQ, in the presence or absence of 1-HP. Simultaneous exposure to 3-o-C12-L-HSL or HHQ together with 1-HP, reduced induction of AhR related genes by 1-HP (Fig.5A and Fig.S8A-D). Moreover, Cyp1a enzymatic activity was diminished when zebrafish larvae were co-exposed to 3-o-C12-L-HSL, HHQ and PQS, together with 1-HP, whereas C4-L-HSL did not affect 1HP induced activation (Fig.5B and Fig.S8B). Remarkably, 3-o-C12-L-HSL and HHQ even inhibited AhR activation by TCDD (Fig.5A, B and Fig.S8A,B). Microarray analysis further confirmed that 3-o-C12-L-HSL inhibited AhR activation by 1-HP (Table S5). None of the ligands induced toxicity in zebrafish larvae, under the conditions tested (Fig.S8E). Overall, our results demonstrate that zebrafish AhR recognizes diverse P.aeruginosa QS molecules.

Taking advantage of P.aeruginosa mutants producing dissimilar levels of distinct QS molecules, we tested whether $\mathrm{AhR}$ is differentially modulated in vivo in response to bacteria 
expressing different QS molecules. We used the mutant PA14 $\Delta r s a L$ and PA14 09480 P.aeruginosa strains, which overproduce 3-o-C12-L-HSL $(27,41)$ or phenazines(10), respectively. No differences in bacterial growth or in the sequential expression of QS molecules were observed amongst these strains (Fig.S9A, B), whereas the levels of 3-o-C12-L-HSL and phenazines differed as previously documented (Fig.S9C). Consistent with earlier studies(41), Pyo levels were also elevated in the PA14 $\Delta r s a L$, when compared to PA14-WT (Fig.S9C). Therefore, we focused on bacteria collected from one distinct growth phase (mid log phase), with consistent differences in the levels of 3-o-C12-L-HSL and Pyo (Fig.5C). Static immersion of larvae to similar bacterial numbers $\left(1 \times 10^{9} \mathrm{CFU} / \mathrm{mL}\right.$, Fig.S10A), led to distinct Cyp1a expression and activity (Fig.5D,E), apparently related to the proportions of the AhR activators and inhibitors (Fig.5C and Fig.S10B). Higher expression of phenazines (PA14 09480) increased, whereas higher expressions of 3-o-C12-L-HSL (PA14 $\Delta r s a L$ ) decreased Cyp1a activity as compared to PA14 WT (Fig.5E). We conclude that AhR recognition of these molecules, whose expressions are tightly regulated in P.aeruginosa, allows for quantitative sensing of the course of infection.

Recognition of phenazines by AhR is important for clearance of P.aeruginosa(10). Infection of WT and $A h R^{-/-}$mice with a Pyo overexpressing strain (PA14 09480)(10) (Fig.S9C, S11A) confirmed the importance of the AhR in bacterial clearance in responses to these molecules (Fig.6A). Intriguingly, infection with bacteria from earlier stages of growth, not expressing phenazines (Fig.S11A), had detrimental consequences mediated by the AhR (Fig.6A). These results further illustrate that distinct P.aeruginosa molecules expressed at different growth stages modulate AhR signalling differentially. In order to evaluate the impact of AhR sensing of QS molecules expressed at early stages, focusing on the AhR inhibitor 3-oC12-L-HSL identified here, we infected mice with the P.aeruginosa strain (PA14 $\Delta r s a L)$. We focused on bacteria from mid log growth phase, to exclude differences in lung CFUs between the 2 mouse strains (WT and $A h R^{--}$) after $8 \mathrm{~h}$ of infection (Fig.S11B, C). Differential expression of various cytokines and chemokines depended not only on the mouse strain, but also on the P.aeruginosa strain (Fig.6B, C and Fig.S11D). These in vivo results are consistent with our in vitro experiments (Fig.3E, F), where AhR differentially regulated expression of distinct cytokines and chemokines, depending on the presence of distinct QS molecules. Previously we reported a critical role of $\mathrm{AhR}$ in the recruitment of neutrophils to the lungs of P.aeruginosa infected mice(10). Likewise, lower numbers of neutrophils were detected in the lungs of $A h R^{-}$ ${ }^{1-}$ mice upon infection with PA14 WT (Fig.6D). Strikingly, these differences were lost when 
infecting mice with PA14 $\Delta r s a L$, where we observed comparable numbers of neutrophils in the lungs of WT and $A h R^{-/-}$mice (Fig.6D).

In sum, these results reveal differential modulation of AhR during the course of infection, depending on the relative abundances of distinct QS molecules. Taken together, our data determines that the AhR not only detects P.aeruginosa QS molecules in a qualitative way, but rather quantifies their relative levels. This quantitative assessment endows the host with the capacity to sense bacterial community densities, and consequently infection dynamics. Thus, our findings emphasize a crucial role of $\mathrm{AhR}$ as master regulator of host defence responses, capable of tuning immunity according to the stage of infection and disease and hence to their threat to the host.

\section{Discussion}

Recently we revealed that by binding bacterial pigmented virulence factors, such as P.aeruginosa phenazines, AhR regulates host resistance to infection(10). Here, we demonstrate that, in addition to phenazines, AhR recognizes QS molecules comprising different chemical entities including homoserine lactones and quinolones. In contrast to phenazines, the QS cognates, 3-o-C12-L-HSL and HHQ, inhibit the canonical AhR signalling by competing and antagonizing effects of known AhR activators, such as P.aeruginosa 1-HP(10), or the bona fide AhR ligand, $\operatorname{TCDD}(19,42)$. Strikingly, AhR sensing of QS molecules is not restricted to a particular cell type or a specific in vitro model: First, mammalian macrophages, hepatocytes and epithelial cells responded in a similar fashion, and in all cases subtle alterations in the ratios of bacterial ligands influenced the outcome of AhR activation and its downstream responses, such as cytokine and chemokine expression. Second, these results are reciprocated in vivo using zebrafish, where exposure of larvae to different concentrations of P.aeruginosa QS molecules modulated AhR activation and elicited downstream responses. Moreover, exposure of zebrafish larvae to different P.aeruginosa mutants producing distinct QS molecules at different abundances at a given point of infection, resulted in a unique AhR activation profile. Complementing these findings, an experimental mouse infection model with P.aeruginosa strains expressing variable levels of QS molecules, revealed that the AhR regulates bacterial elimination upon sensing bacterial quorum. In sum, the AhR resembles a "processing-hub", integrating the information linked to the abundance of different QS molecules, both activators 
and inhibitors, thereby mobilizing the most appropriate host defence mechanisms at a given stage of infection.

QS is employed by certain bacteria to coordinate their gene expression in response to changes in their population density, or their stage of infection(1,3,4). Accordingly, direct correlation between different QS molecules, and severity of infection has been observed(7, 43). In P.aeruginosa, QS is crucial for coordinated colonization of a new environment, regulating different virulence and adaptation mechanisms(1, 3, 4, 12). Differences in P.aeruginosa virulence and transition from acute to chronic infection have been linked to altered expression of QS molecules and their regulated genes $(1,6,8,43)$. For instance, the expression of phenazines plays a critical role in biofilm formation and development $(7,43,44)$, and $P$. aeruginosa QS mutants producing thinner and less developed biofilms, are more sensitive to antibiotics and eradication $(1,5,45)$. Furthermore, high concentrations of $P$. aeruginosa phenazines are detected in the sputum of CF patients, who are severely affected by this pathogen $(2,7,43)$. Therefore, depending on its metabolic state, mirrored by a distinct composition of QS molecules, the bacteria may pose different threats to the host, who needs to adapt its response accordingly. Interestingly, inter- and intra- P.aeruginosa species differences in virulence and expression of secreted molecules have been reported to occur, not restricted to clinical isolates but also among laboratory strains (e.g. between PAO1 sublines or between PA14 and PAO1). For example, expression levels of Pyo, rhamnolipids, PQS, exopolysaccharides and elastase have been reported to differ between PA14 and PAO1 or among diverse PAO1 sublines(46-49). It is tempting to speculate that due to its capacity to detect different levels of P.aeruginosa QS molecules, including Pyo or PQS, the AhR is also well suited to detect strain-related differences during the course of infection, and consequently regulate host responses accordingly. Though, further studies are needed to evaluate this hypothesis.

Interactions of P.aeruginosa QS molecules with different host receptors and signalling pathways have been reported(9). For example, 3-o-C12-L-HSL has been found to be sensed by the Ras GTPase-activating-like protein IQGAP1 or the Peroxisome proliferator-activated receptors (PPAR $\beta / \delta / \gamma)(9,50,51)$. Additionally, P.aeruginosa HSLs (e.g. 3-o-C12-L-HSL) and quinolones (HHQ and PQS) modulate different host signalling pathways, involving NF$\mathrm{kB}$ or $\operatorname{PPAR}(9,51-53)$. Curiously, interactions between the AhR and the indicated signalling pathways (e.g. NF-kB and PPAR) have been described(19), but their interplay and elicited responses upon P.aeruginosa infection remain unknown, and should be the focus of future 
studies. Nevertheless, the unique capacity of the AhR to bind and recognize three distinct types of QS molecules (HSLs, quinolones and phenazines), as well as its capacity to monitor and integrate their relative expression levels, endorses this receptor as a unique and major host sensor of bacterial quorum and infection dynamics. It is tempting to speculate that host $\mathrm{AhR}$ and bacterial QS systems can actively spy on each other by recognizing similar molecules, even beyond the QS molecules described here. Recently Ismail et al(54) described that host epithelia can produce QS-like molecules, including an AI-2 mimic, enabling it to interfere bacterial QS circuits. Bacteria derived AI-2 does not modulate the AhR pathway in epithelial cells (unpublished data). However, due to its capacity to sense P.aeruginosa QS molecules and to its vast ligand binding properties, we cannot exclude the possibility that the host AhR senses and modulates the expression of different host molecules (such as host QS-like molecules and others), which may be involved in this host-bacteria interkingdom crosstalk during infection (grey arrows in Fig.1A).

Given that the AhR acts as host sensor which monitors different QS molecules and their expression profiles along the course of infection and disease, the host can tune immune defence according to the stage and density of the bacterial community and the threat of infection. This mechanism would be particularly apt for nosocomial pathogens, which can be tolerated by the immunocompetent host at low density but become harmful once a threshold of tolerability has been exceeded. In this way, cost of energy for defence would be focused on the harmful trait only, with the harmless trait being ignored. Because $P$. aeruginosa is an opportunistic pathogen, defence mobilization is avoided at low bacterial densities, which can be tolerated, and it kicks in only with increasing population densities, which can harm the host. We propose that by spying on inter-bacterial communication, AhR is capable of sensing the status quo of the P.aeruginosa community during infection, allowing the host to mobilize the most appropriate defence mechanism according to the severity of threat.

\section{References and Notes:}

1. M. F. Moradali, S. Ghods, B. H. Rehm, Pseudomonas aeruginosa Lifestyle: A Paradigm for Adaptation, Survival, and Persistence. Front Cell Infect Microbiol 7, 39 (2017).

2. J. C. Davies, Pseudomonas aeruginosa in cystic fibrosis: pathogenesis and persistence. Paediatr Respir Rev 3, 128-134 (2002).

3. K. Papenfort, B. L. Bassler, Quorum sensing signal-response systems in Gramnegative bacteria. Nat Rev Microbiol 14, 576-588 (2016).

4. C. M. Waters, B. L. Bassler, Quorum sensing: cell-to-cell communication in bacteria. Annu Rev Cell Dev Biol 21, 319-346 (2005). 
$430 \quad 5 . \quad$ P. C. Shih, C. T. Huang, Effects of quorum-sensing deficiency on Pseudomonas aeruginosa biofilm formation and antibiotic resistance. J Antimicrob Chemother 49, 309-314 (2002).

6. C. Winstanley, J. L. Fothergill, The role of quorum sensing in chronic cystic fibrosis Pseudomonas aeruginosa infections. FEMS Microbiol Lett 290, 1-9 (2009).

7. B. Rada, T. L. Leto, Pyocyanin effects on respiratory epithelium: relevance in Pseudomonas aeruginosa airway infections. Trends Microbiol 21, 73-81 (2013).

8. H. L. Barr et al., Pseudomonas aeruginosa quorum sensing molecules correlate with clinical status in cystic fibrosis. Eur Respir J 46, 1046-1054 (2015).

9. Y. C. Liu, K. G. Chan, C. Y. Chang, Modulation of Host Biology by Pseudomonas aeruginosa Quorum Sensing Signal Molecules: Messengers or Traitors. Front Microbiol 6, 1226 (2015).

10. P. Moura-Alves et al., AhR sensing of bacterial pigments regulates antibacterial defence. Nature 512, 387-392 (2014).

11. L. E. Dietrich, A. Price-Whelan, A. Petersen, M. Whiteley, D. K. Newman, The phenazine pyocyanin is a terminal signalling factor in the quorum sensing network of Pseudomonas aeruginosa. Mol Microbiol 61, 1308-1321 (2006).

12. P. N. Jimenez et al., The multiple signaling systems regulating virulence in Pseudomonas aeruginosa. Microbiol Mol Biol Rev 76, 46-65 (2012).

13. A. Crabbe et al., Alveolar epithelium protects macrophages from quorum sensinginduced cytotoxicity in a three-dimensional co-culture model. Cell Microbiol 13, 469481 (2011).

14. K. Tateda et al., The Pseudomonas aeruginosa autoinducer N-3-oxododecanoyl homoserine lactone accelerates apoptosis in macrophages and neutrophils. Infect Immun 71, 5785-5793 (2003).

15. J. P. Pearson et al., Structure of the autoinducer required for expression of Pseudomonas aeruginosa virulence genes. Proc Natl Acad Sci U S A 91, 197-201 (1994).

16. T. S. Charlton et al., A novel and sensitive method for the quantification of N-3oxoacyl homoserine lactones using gas chromatography-mass spectrometry: application to a model bacterial biofilm. Environ Microbiol 2, 530-541 (2000).

17. D. L. Erickson et al., Pseudomonas aeruginosa quorum-sensing systems may control virulence factor expression in the lungs of patients with cystic fibrosis. Infect Immun 70, 1783-1790 (2002).

18. P. K. Singh et al., Quorum-sensing signals indicate that cystic fibrosis lungs are infected with bacterial biofilms. Nature 407, 762-764 (2000).

19. B. Stockinger, P. Di Meglio, M. Gialitakis, J. H. Duarte, The aryl hydrocarbon receptor: multitasking in the immune system. Annu Rev Immunol 32, 403-432 (2014).

20. C. Schiering et al., Feedback control of AHR signalling regulates intestinal immunity. Nature 542, 242-245 (2017).

21. E. Wincent et al., Inhibition of cytochrome P4501-dependent clearance of the endogenous agonist FICZ as a mechanism for activation of the aryl hydrocarbon receptor. Proc Natl Acad Sci U S A 109, 4479-4484 (2012).

22. C. J. Sinal, J. R. Bend, Aryl hydrocarbon receptor-dependent induction of cyp1a1 by bilirubin in mouse hepatoma hepa 1c1c7 cells. Mol Pharmacol 52, 590-599 (1997).

23. A. Pandini, M. S. Denison, Y. Song, A. A. Soshilov, L. Bonati, Structural and functional characterization of the aryl hydrocarbon receptor ligand binding domain by homology modeling and mutational analysis. Biochemistry 46, 696-708 (2007). 
24. A. Pandini et al., Detection of the TCDD binding-fingerprint within the Ah receptor ligand binding domain by structurally driven mutagenesis and functional analysis. Biochemistry 48, 5972-5983 (2009).

25. A. A. Soshilov, M. S. Denison, Ligand promiscuity of aryl hydrocarbon receptor agonists and antagonists revealed by site-directed mutagenesis. Mol Cell Biol 34, 1707-1719 (2014).

26. R. Pohjanvirta, The AH Receptor in Biology and Toxicology. (Wiley, 2011).

27. F. Massai et al., A multitask biosensor for micro-volumetric detection of N-3-oxododecanoyl-homoserine lactone quorum sensing signal. Biosens Bioelectron 26, 34443449 (2011).

28. M. Fletcher, M. Camara, D. A. Barrett, P. Williams, Biosensors for qualitative and semiquantitative analysis of quorum sensing signal molecules. Methods Mol Biol 1149, 245-254 (2014).

29. C. Esser, A. Rannug, The aryl hydrocarbon receptor in barrier organ physiology, immunology, and toxicology. Pharmacol Rev 67, 259-279 (2015).

30. M. L. Mayer, J. A. Sheridan, C. J. Blohmke, S. E. Turvey, R. E. Hancock, The Pseudomonas aeruginosa autoinducer 30-C12 homoserine lactone provokes hyperinflammatory responses from cystic fibrosis airway epithelial cells. PLoS One 6 , e16246 (2011).

31. R. S. Smith et al., IL-8 production in human lung fibroblasts and epithelial cells activated by the Pseudomonas autoinducer N-3-oxododecanoyl homoserine lactone is transcriptionally regulated by NF-kappa B and activator protein-2. J Immunol 167, 366-374 (2001).

32. P. Ramadoss, G. H. Perdew, Use of 2-azido-3-[125I]iodo-7,8-dibromodibenzo-pdioxin as a probe to determine the relative ligand affinity of human versus mouse aryl hydrocarbon receptor in cultured cells. Mol Pharmacol 66, 129-136 (2004).

33. A. Planchart et al., Advancing toxicology research using in vivo high throughput toxicology with small fish models. ALTEX 33, 435-452 (2016).

34. S. A. Renshaw, N. S. Trede, A model 450 million years in the making: zebrafish and vertebrate immunity. Dis Model Mech 5, 38-47 (2012).

35. A. H. Meijer, H. P. Spaink, Host-pathogen interactions made transparent with the zebrafish model. Curr Drug Targets 12, 1000-1017 (2011).

36. T. C. King-Heiden et al., Reproductive and developmental toxicity of dioxin in fish. Mol Cell Endocrinol 354, 121-138 (2012).

37. J. J. van Soest et al., Comparison of static immersion and intravenous injection systems for exposure of zebrafish embryos to the natural pathogen Edwardsiella tarda. BMC Immunol 12, 58 (2011).

38. F. Diaz-Pascual, J. Ortiz-Severin, M. A. Varas, M. L. Allende, F. P. Chavez, In vivo Host-Pathogen Interaction as Revealed by Global Proteomic Profiling of Zebrafish Larvae. Front Cell Infect Microbiol 7, 334 (2017).

39. B. Zhao, D. E. Degroot, A. Hayashi, G. He, M. S. Denison, CH223191 is a ligandselective antagonist of the Ah (Dioxin) receptor. Toxicol Sci 117, 393-403 (2010).

40. M. E. Jonsson, A. Kubota, A. R. Timme-Laragy, B. Woodin, J. J. Stegeman, Ahr2dependence of PCB126 effects on the swim bladder in relation to expression of CYP1 and cox-2 genes in developing zebrafish. Toxicol Appl Pharmacol 265, 166-174 (2012).

41. M. T. Cabeen, Stationary phase-specific virulence factor overproduction by a lasR mutant of Pseudomonas aeruginosa. PLoS One 9, e88743 (2014).

42. P. K. Mandal, Dioxin: a review of its environmental effects and its aryl hydrocarbon receptor biology. J Comp Physiol B 175, 221-230 (2005). 
43. R. C. Hunter et al., Phenazine content in the cystic fibrosis respiratory tract negatively correlates with lung function and microbial complexity. Am J Respir Cell Mol Biol 47, 738-745 (2012).

44. I. Ramos, L. E. Dietrich, A. Price-Whelan, D. K. Newman, Phenazines affect biofilm formation by Pseudomonas aeruginosa in similar ways at various scales. Res Microbiol 161, 187-191 (2010).

45. L. K. Nelson, G. H. D'Amours, K. M. Sproule-Willoughby, D. W. Morck, H. Ceri, Pseudomonas aeruginosa las and rhl quorum-sensing systems are important for infection and inflammation in a rat prostatitis model. Microbiology 155, 2612-2619 (2009).

46. J. Klockgether et al., Genome diversity of Pseudomonas aeruginosa PAO1 laboratory strains. J Bacteriol 192, 1113-1121 (2010).

47. L. Wiehlmann et al., Population structure of Pseudomonas aeruginosa. Proc Natl Acad Sci U S A 104, 8101-8106 (2007).

48. C. E. Chandler et al., Genomic and Phenotypic Diversity among Ten Laboratory Isolates of Pseudomonas aeruginosa PAO1. J Bacteriol 201, (2019).

49. S. Chugani et al., Strain-dependent diversity in the Pseudomonas aeruginosa quorumsensing regulon. Proc Natl Acad Sci U S A 109, E2823-2831 (2012).

50. T. Karlsson, M. V. Turkina, O. Yakymenko, K. E. Magnusson, E. Vikstrom, The Pseudomonas aeruginosa $\mathrm{N}$-acylhomoserine lactone quorum sensing molecules target IQGAP1 and modulate epithelial cell migration. PLoS Pathog 8, e1002953 (2012).

51. A. Jahoor et al., Peroxisome proliferator-activated receptors mediate host cell proinflammatory responses to Pseudomonas aeruginosa autoinducer. J Bacteriol 190, 4408-4415 (2008).

52. V. V. Kravchenko et al., Modulation of gene expression via disruption of NF-kappaB signaling by a bacterial small molecule. Science 321, 259-263 (2008).

53. K. Kim et al., HHQ and PQS, two Pseudomonas aeruginosa quorum-sensing molecules, down-regulate the innate immune responses through the nuclear factorkappaB pathway. Immunology 129, 578-588 (2010).

54. A. S. Ismail, J. S. Valastyan, B. L. Bassler, A Host-Produced Autoinducer-2 Mimic Activates Bacterial Quorum Sensing. Cell Host Microbe 19, 470-480 (2016).

55. M. W. Pfaffl, A new mathematical model for relative quantification in real-time RTPCR. Nucleic Acids Res 29, e45 (2001).

56. L. Lozza et al., Crosstalk between human DC subsets promotes antibacterial activity and CD8+ T-cell stimulation in response to bacille Calmette-Guerin. Eur J Immunol 44, 80-92 (2014).

57. A. Mohammadi-Bardbori, Assay for quantitative determination of CYP1A1 enzyme activity using 7-Ethoxyresorufin as standard substrate (EROD assay). (2014).

58. M. E. Ritchie et al., limma powers differential expression analyses for RNAsequencing and microarray studies. Nucleic Acids Res 43, e47 (2015).

59. J. Weiner 3rd, Domaszewska, T., tmod: an R package for general and multivariate enrichment analysis. PeerJ Preprints 4:e2420v1, (2016).

60. J. Zyla, M. Marczyk, J. Weiner, J. Polanska, Ranking metrics in gene set enrichment analysis: do they matter? BMC Bioinformatics 18, 256 (2017).

61. N. Eswar et al., Comparative protein structure modeling using Modeller. Curr Protoc Bioinformatics Chapter 5, Unit-5 6 (2006).

62. M. Y. Shen, A. Sali, Statistical potential for assessment and prediction of protein structures. Protein Sci 15, 2507-2524 (2006).

63. T. A. Halgren et al., Glide: a new approach for rapid, accurate docking and scoring. 2. Enrichment factors in database screening. J Med Chem 47, 1750-1759 (2004). 
64. N. Huang et al., Crystal structure of the heterodimeric CLOCK:BMAL1 transcriptional activator complex. Science 337, 189-194 (2012).

65. C. Nüsslein-Volhard, Dahm, R., Zebrafish. C. Nüsslein-Volhard, Dahm, R., Ed., (Oxford University Press, 2002), pp. 303.

66. D. C. Nacci, L; Kuhn,A; Champlin, D; Munns, W; Specker, J; Cooper, K, Nondestructive indicator of ethoxyresorufin-O-deethylase activity in embryonic fish. ENVIRONMENTAL TOXICOLOGY AND CHEMISTRY 17, 2481-2486 (1998).

67. V. Link, A. Shevchenko, C. P. Heisenberg, Proteomics of early zebrafish embryos. BMC Dev Biol 6, 1 (2006).

68. S. Subramoni, V. Venturi, LuxR-family 'solos': bachelor sensors/regulators of signalling molecules. Microbiology 155, 1377-1385 (2009).

69. A. Neumann, D. Patzelt, I. Wagner-Dobler, S. Schulz, Identification of new Nacylhomoserine lactone signalling compounds of Dinoroseobacter shibae DFL-12(T) by overexpression of luxI genes. Chembiochem 14, 2355-2361 (2013).

70. M. Elasri et al., Acyl-homoserine lactone production is more common among plantassociated Pseudomonas spp. than among soilborne Pseudomonas spp. Appl Environ Microbiol 67, 1198-1209 (2001).

71. R. L. Ulrich et al., Role of quorum sensing in the pathogenicity of Burkholderia pseudomallei. J Med Microbiol 53, 1053-1064 (2004).

72. R. L. Ulrich, D. Deshazer, H. B. Hines, J. A. Jeddeloh, Quorum sensing: a transcriptional regulatory system involved in the pathogenicity of Burkholderia mallei. Infect Immun 72, 6589-6596 (2004).

73. G. Brader, S. Sjoblom, H. Hyytiainen, K. Sims-Huopaniemi, E. T. Palva, Altering substrate chain length specificity of an acylhomoserine lactone synthase in bacterial communication. J Biol Chem 280, 10403-10409 (2005).

74. A. M. Pomini, G. P. Manfio, W. L. Araujo, A. J. Marsaioli, Acyl-homoserine lactones from Erwinia psidii R. IBSBF 435T, a guava phytopathogen (Psidium guajava L.). $J$ Agric Food Chem 53, 6262-6265 (2005).

75. O. Geisenberger et al., Production of N-acyl-L-homoserine lactones by P. aeruginosa isolates from chronic lung infections associated with cystic fibrosis. FEMS Microbiol Lett 184, 273-278 (2000).

76. G. D. Geske, J. C. O'Neill, D. M. Miller, M. E. Mattmann, H. E. Blackwell, Modulation of bacterial quorum sensing with synthetic ligands: systematic evaluation of $\mathrm{N}$-acylated homoserine lactones in multiple species and new insights into their mechanisms of action. $J$ Am Chem Soc 129, 13613-13625 (2007).

77. G. D. Geske, R. J. Wezeman, A. P. Siegel, H. E. Blackwell, Small molecule inhibitors of bacterial quorum sensing and biofilm formation. J Am Chem Soc 127, 12762-12763 (2005).

78. V. Nagar, V. Sinha, J. R. Bandekar, Diverse Profiles of N-acyl Homoserine LLactones, Biofilm, Virulence Genes and Integrons in Food-Borne Aeromonas Isolates. J Food Sci 80, M1861-1870 (2015).

79. A. L. Schaefer et al., A new class of homoserine lactone quorum-sensing signals. Nature 454, 595-599 (2008).

80. K. Riedel et al., N-acylhomoserine-lactone-mediated communication between Pseudomonas aeruginosa and Burkholderia cepacia in mixed biofilms. Microbiology 147, 3249-3262 (2001).

81. P. Williams, Quorum sensing, communication and cross-kingdom signalling in the bacterial world. Microbiology 153, 3923-3938 (2007).

82. J. P. Kirwan et al., Quorum-sensing signal synthesis by the Yersinia pestis acylhomoserine lactone synthase YspI. J Bacteriol 188, 784-788 (2006). 
83. C. A. Ortori et al., Comprehensive profiling of $\mathrm{N}$-acylhomoserine lactones produced by Yersinia pseudotuberculosis using liquid chromatography coupled to hybrid quadrupole-linear ion trap mass spectrometry. Anal Bioanal Chem 387, 497-511 (2007).

84. A. Rajput, K. Kaur, M. Kumar, SigMol: repertoire of quorum sensing signaling molecules in prokaryotes. Nucleic Acids Res 44, D634-639 (2016).

85. M. W. Tan, S. Mahajan-Miklos, F. M. Ausubel, Killing of Caenorhabditis elegans by Pseudomonas aeruginosa used to model mammalian bacterial pathogenesis. Proc Natl Acad Sci U S A 96, 715-720 (1999).

86. E. K. Shiner et al., Pseudomonas aeruginosa autoinducer modulates host cell responses through calcium signalling. Cell Microbiol 8, 1601-1610 (2006).

Acknowledgments: The authors gratefully acknowledge those who have provided tools and materials for this work. Brigitta Stockinger (The Francis Crick Institute, London, UK) for the $A h R^{-/-}$mice. Clemens Grabher (Karlsruhe Institute of Technology, Karlsruhe, Germany) and Daniela Panakova (Max Delbruck Center, Berlin, Germany) for the zebrafish AB WT strain. Livia Leoni (University Roma Tre, Rome, Italy) for P.aeruginosa strains PA14 $\Delta r s a L$ and PA14-R3; Burkhard Tuemmler (Medizinsche Hochschule Hannover, Germany) for PA14 WT and PA14 09480; Fred Ausubel (Harvard Medical School/Massachusetts General Hospital, Boston, USA) for PA14-GFP; Paul Williams (University of Nottingham, Nottingham, UK) for PAO1 WT, PAO1 pqsA CTX-lux::pqsA. We acknowledge Uwe Klemm for mouse breedings and Norman Fielko, Jens Otto, Andrey Fadeev (Max Planck Institute for Infection Biology, Berlin, Germany) and Mariana Simões (Max Delbruck Center, Berlin, Germany) for zebrafish breedings. Anne Diehl (Leibniz-Institut for Molekulare Pharmakologie, Berlin, Germany) for technical help to prepare mouse liver lysates. A special thanks to Annemarie Meijer and Vincenzo Torraca (University of Leiden, Leiden, The Netherlands) for the support in setting up a zebrafish facility, zebrafish handling and experimental design; Funding: This work was generously supported by the Max Planck Society; AS and MKB work was funded by the European Research Council under the Horizon 2020 programme of the European Commission, grant number 311371; FK and GBW acknowledge support from the Helmholtz BioInterfaces in Technology and Medicine (BIFTM) program of KIT; Author contributions: PM-A and SHEK conceived and designed the study and wrote the manuscript. PM-A designed and performed experiments and data analysis. AP, GP, UG and MK provided technical help for in vitro and in vivo experiments. AD, PS and CP performed mouse infection experiments. LL performed and analysed Fluidigm experiments. MKB, AS and JF performed binding studies. RH, FK and GBW performed and analysed HPLC experiments. AK, JP, GK and HO performed virtual docking studies. HJM and JW performed and analysed microarray experiments. All 
authors commented on the paper; Competing interests: Authors declare no competing interests; Data and materials availability: All data is available in the main text or the supplementary materials. Data are deposited in GEO under accession number GSE121101.

\section{Supplementary Materials:}

Materials and Methods

Figs. S1 to S11

Tables S1 to S11

References (55-86)

Fig. 1. AhR modulation by $\boldsymbol{P}$. aeruginosa. (A) Scheme of AhR sensing of P.aeruginosa $\mathrm{QS}$ molecules during infection. P.aeruginosa signalling cascade during different bacterial growth stages. QS molecules depicted in black and proteins in coloured circles, with different colours corresponding to each QS molecule. Black arrow with asterisk depicts known interaction between P.aeruginosa phenazines and host AhR. (B, C) Luciferase activity of AhR reporter THP-1 (monocytic) and A549 (pneumocytic) cells upon 24h (B) infection with P.aeruginosa PA14-wild type (WT) strain grown in lysogeny broth (LB) medium, at a multiplicity of infection (MOI) 50 ( $\mathrm{n}=3$ independent experiments) or (C) stimulation with P.aeruginosa filtered supernatants (1:25 diluted), collected from different bacterial growth phases $(n=4$ independent experiments). (D) Expression of QS molecules in supernatants of PA14 WT, detected by high-performance liquid chromatography (HPLC). Data from 1 representative experiment out of 2 independent experiments. (E-G) Luciferase activity of AhR reporter THP1 and A549 cells upon 4h stimulation with different concentrations of P.aeruginosa homoserine lactones (3-o-C12-L-HSL or C4-L-HSL) and quinolones (HHQ or PQS) in (E) absence (THP-1 $(n=6)$ or A549 $(n=4)$ independent experiments) or $(\mathbf{F}, \mathbf{G})$ presence of P.aeruginosa 1-hydroxyphenazine (1-HP; pooled data from: F- THP-1 ( $n=3)$ or A549 $(n=4)$ independent experiments; G- THP-1 ( $n=3)$, A549 top ( $n=9)$, A549 bottom ( $n=3)$ independent experiments). (H) CYP1A1 gene expression upon 24h stimulation of A549 cells with QS molecules. Data from 1 representative experiment out of at least 3 independent experiments ( $\mathrm{n}=3$ biological replicates). (I, J) CYP1A1 enzymatic activity after 24h stimulation of Hepa1c1c7 cells with (I) 1-HP $(50 \mu \mathrm{M})$, in $(\mathbf{J})$ presence or absence of other QS molecules. Data are pooled from: I $(n=7)$ or $J(n=4)$ independent experiments. Pyo: pyocyanin, 1-HP: 1- 
696

697

698

hydroxyphenazine, PCA: phenazine-1 carboxylic acid, PCN: phenazine carboxamide, 3-oC12-L-HSL: N-(3-oxodecanoyl)-L-homoserine lactone, C4-L-HSL: N-butyril-L-homoserine lactone, HHQ: 4-hydroxy-2-heptylquinoline, PQS: 2-heptyl-3,4- dihydroxyquinoline, IQS: 2(2 -hydroxylphenyl)-thiazole-4-carbaldehyde. (B-C,E-G,I) Means +/- S.E.M. are depicted (H) Means +/- S.D. are depicted. (B,C,E,F,H, J) One-way ANOVA. (I) Two-tailed Student's ttest. $* \mathrm{p}<0.05, * * \mathrm{P}<0.01, * * * \mathrm{p}<0.001, * * * * \mathrm{p}<0.0001$

Fig. 2- Binding of P.aeruginosa QS molecules to AhR. (A) In silico docking of P.aeruginosa QS molecules into the AhR ligand binding pocket. (B,C) Binding of QS molecules to AhR measured by (B) displacement of radioactive $\left[{ }^{3} \mathrm{H}\right]$ labelled 2,3,7,8-tetrachlorodibenzodioxin (TCDD, $\left[{ }^{3} \mathrm{H}\right] \mathrm{TCDD}$ ) from AhR in WT mouse liver cytosol and (C) Microscale thermophoresis assay. (B) (Kd values: 3-o-C12-L-HSL=4.67 $\mu \mathrm{M} \mathrm{HHQ}=3.77 \mu \mathrm{M}$; 1-HP=4.48 $\mu \mathrm{M})$. (C) $(\mathrm{Kd}$ values: 3-o-C12-L-HSL= $2.69 \mu \mathrm{M} ; \mathrm{PQS}=130 \mu \mathrm{M} ; 1-\mathrm{HP}=1.18 \mu \mathrm{M})$. (B) Data are pooled from: 3-o-C12-L-HSL ( $n=3)$, C-4-L-HSL $(n=2)$, HHQ $(n=4)$, PQS $(n=2)$ or 1-HP $(n=3)$ independent experiments (C) Data are pooled from: 3-o-C12-L-HSL ( $n=4)$, C4-L-HSL ( $n=3$ ), PQS $(n=4)$ or 1-HP $(n=4)$ independent experiments.

Fig. 3- AhR dependent responses. (A) Western blot detection of AhR protein expression in A549 CRISPR Scramble control and CRISPR AhR-KO cells. (B-D) Degradation of (B,C) 3o-C12-L-HSL or (D) HHQ, measured in the supernatants of stimulated A549 CRISPR cells, compared to control without cells. 3-o-C12-L-HSL expression levels detected by (B) bacterial PA14-R3 bioluminescence reporter assay ( $n=3$ independent experiments) or (C) HPLC $(n=3$ independent experiments), and (D) expression of HHQ detected by HPLC ( $\mathrm{n}=4$ independent experiments). (E,F) Gene expression analysis of different cytokines and chemokines in A549 CRISPR cells upon 24h stimulation with $P$. aeruginosa QS molecules. Data are pooled from: 3-o-C12-L-HSL (n=6), HHQ $(n=5)$ or 1-HP $(n=7)$ independent experiments. (B-D,F) Data depicted as means +/- S.E.M. (B) Two-way ANOVA. (F) Two-tailed Student's t-test. n.s.- not significant, $* \mathrm{p}<0.05, * * \mathrm{p}<0.01, * * * \mathrm{p}<0.001$ and $* * * * \mathrm{p}<0.0001$. 
Fig. 4-AhR activation by P.aeruginosa QS molecules in zebrafish larvae. (A) Expression of 3-o-C12-L-HSL and Pyo in supernatants of P.aeruginosa (PA14) WT strain, collected at different growth phases in LB medium. 3-o-C12-L-HSL determined by PA14-R3 bioluminescence reporter assay and Pyo concentrations evaluated by spectrophotometry $(n=9$ independent experiments). (B-D) cypla expression in 2dpf zebrafish larvae (B,D) infected by immersion with PA14WT strain or (C) exposed to bacterial supernatants for $5 \mathrm{~h}(\mathrm{n}=7$ independent experiments). (B,D) Infection with (B) different bacterial loads collected from various phases of PA14 WT growth, according to the defined final OD600 in E3 (adjusted to Early $\log -\mathrm{OD} 600=0.2 ;$ Mid $\log -\mathrm{OD} 600=0.7 ;$ Late $\log -\mathrm{OD} 600=1 ; \mathrm{n}=3$ independent experiments) or (D) $1 \times 10^{9}$ colony forming units (CFU)/mL infection with PA14WT collected from various phases of bacterial growth ( $\mathrm{n}=7$ independent experiments). (E) Gene expression analysis of cypla, ahrra and ahrrb transcripts from zebrafish larvae (2 days post-fertilization, dpf) treated (red) or untreated (blue) for $2 \mathrm{~h}$ with $5 \mu \mathrm{M}$ of the AhR inhibitor CH223191, followed by further $4 \mathrm{~h}$ exposure with 1-HP $(5 \mu \mathrm{M})$ or DMSO vehicle control. One representative experiment out of at least 3 independent experiments. Triplicates of 12 larvae depicted at each data point. (F) Cyp1a protein expression detected by Western Blot analysis in 2dpf zebrafish larvae treated for $24 \mathrm{~h}$ with DMSO, 1-HP $(5 \mu \mathrm{M})$, in the presence or absence of CH223191 $(5 \mu \mathrm{M})$. (G) Cyp1a enzymatic activity expressed as total intensity of resorufin (EROD assay) detected per 2dpf larvae treated (red) or not (blue) for $2 \mathrm{~h}$ with $\mathrm{CH} 223191$ (5 $\mu \mathrm{M})$ followed by further $4 \mathrm{~h}$ exposure with 1 -HP $(5 \mu \mathrm{M})$ or DMSO vehicle control (each dot represents one larvae). One representative experiment out of at least 3 independent experiments. (H,I) Microarray analysis of 2dpf larvae pre-exposed to DMSO or CH223191 $(5 \mu \mathrm{M})$ for $2 \mathrm{~h}$, followed by $4 \mathrm{~h}$ exposure to 1 -HP $(5 \mu \mathrm{M})$ or DMSO, in the presence or absence of $\mathrm{CH} 223191(5 \mu \mathrm{M})$. Pooled data from 5 independent experiments. (H) Venn diagram depicting the differentially expressed genes and (I) AhR gene enrichment curve. (A-D) Means +/- S.E.M. are depicted. (E). Means +/- S.D. are shown. (G) Medians are depicted. (B-E,G) One-way ANOVA. $* \mathrm{p}<0.05, * * \mathrm{P}<0.01, * * * \mathrm{p}<0.001, * * * * \mathrm{p}<0.0001$

Fig. 5- AhR modulation by P.aeruginosa QS molecules in zebrafish larvae. (A,B) Cyp1a (A) gene expression and (B) enzymatic activity upon 4h exposure of 2 dpf larvae to diverse P.aeruginosa QS molecules or TCDD. One representative experiment out of at least 3 independent experiments; (A) triplicates of 12 larvae depicted at each data point; (B) each dot 
757

758

represents one larvae. (C) Expression of 3-o-C12-L-HSL and Pyo in supernatants of P.aeruginosa (PA14) WT strain, collected at different growth phases in LB medium. (C) Expression of 3-o-C12-L-HSL and Pyo in the supernatants of different PA14 strains collected at Mid log growth phase. 3-o-C12-L-HSL determined by PA14-R3 bioluminescence reporter assay and Pyo concentrations evaluated by spectrophotometry ( $\mathrm{n}=6$ independent experiments). (D,E) Infection of $2 \mathrm{dpf}$ zebrafish larvae by immersion for $5 \mathrm{~h}$ with $1 \times 10^{9} \mathrm{CFU} / \mathrm{mL}$ of different P.aeruginosa strains collected at Mid log growth phase. One representative experiment out of at least 3 independent experiments; (D) triplicates of 12 larvae depicted at each data point; (E) each dot represents one larvae. (D) cypla gene expression and (E) Cyp1a enzymatic activity. (A,D) Means +/- S.D. are shown. (B,E) Medians are depicted (C) Means +/-S.E.M. are depicted. (A,B,D,E) One-way ANOVA. * ${ }^{*}<0.05, * * \mathrm{P}<0.01, * * * \mathrm{p}<0.001, * * * * \mathrm{p}<0.0001$.

Fig. 6- AhR mediated responses upon P.aeruginosa infection in mice. (A) Bacterial clearance in the lungs of WT and AhR-knockout $\left(\mathrm{AhR}^{-/}\right)$mice after $8 \mathrm{~h}$ of infection with P.aeruginosa PA14 09480 ( $2 \times 10^{6}$ colony forming units (CFU) administered per mouse). Bacterial growth phases: early $\log -\mathrm{OD} 600<0.3$; mid $\log -0.5<0 D 600<0.8$ and late $\log$ OD600 $>1$. Each dot represents 1 mouse ( $n=2$ independent experiments). (B-D) Infection of $\mathrm{WT}$ and $\mathrm{AhR}^{-/-}$mice for $8 \mathrm{~h}$ with PA14 WT or PA14 $\Delta r s a L$ strains (pooled data from 2 independent experiments). (B) Gene expression analysis of different cytokines and chemokines in the lungs of infected mice, compared to the respective non-infected mouse strain (WT: $n=8$ and $\mathrm{AhR}^{-/-}: \mathrm{n}=6$ mice) $(\mathbf{C})$ Cytokine and chemokine protein levels in lung homogenates after infection. Each dot represents 1 mouse ( $\mathrm{n}=2$ independent experiments) (D) Neutrophil numbers in the lungs of infected and non-infected mice. Each dot represents 1 mouse ( $\mathrm{n}=2$ independent experiments). (A,C,D) Medians are depicted. (B) Means +/- S.E.M. are depicted. (A, D) MannWhitney U-test. (B) Two-tailed Student's t-test. (C) Two-way ANOVA). * p $<0.05$, ** $\mathrm{P}<0.01$, $* * * \mathrm{p}<0.001, * * * * \mathrm{p}<0.0001$. 


\section{Science $\triangle 1$ AAAS}

Supplementary Materials for

\section{Host monitoring of quorum sensing during Pseudomonas aeruginosa infection}

Pedro Moura-Alves ${ }^{1,2^{*}}$, Andreas Puyskens ${ }^{1}$, Anne Stinn ${ }^{1,3,4,5}$, Marion Klemm ${ }^{1}$, Ute GuhlichBornhof $^{1}$, Anca Dorhoi ${ }^{1,6,7}$, Jens Furkert ${ }^{8}$, Annika Kreuchwig ${ }^{8}$, Jonas Protze ${ }^{8}$, Laura Lozza ${ }^{1,9}$, Gang Pei ${ }^{1}$, Philippe Saikali ${ }^{1}$, Carolina Perdomo ${ }^{1}$, Hans J. Mollenkopf ${ }^{10}$, Robert Hurwitz ${ }^{11}$, Frank Kirschhoefer ${ }^{12}$, Gerald Brenner-Weiss ${ }^{11}$, January Weiner $3^{\text {rd1 }}$, Hartmut Oschkinat ${ }^{8}$, Michael Kolbe $^{3,4,5}$, Gerd Krause ${ }^{8}$, Stefan H.E. Kaufmann ${ }^{1,13^{*}}$

${ }^{1}$ Max Planck Institute for Infection Biology, Department of Immunology, Charitéplatz 1, 10117 Berlin, Germany. ${ }^{2}$ Nuffield Department of Clinical Medicine, Ludwig Institute for Cancer Research, University of Oxford, Oxford, UK. ${ }^{3}$ Max Planck Institute for Infection Biology, Structural Systems Biology, Charitéplatz 1, 10117 Berlin, Germany. ${ }^{4}$ Department of Structural Infection Biology, Centre for Structural Systems Biology (CSSB), Helmholtz-Centre for Infection Research (HZI), Notkestraße 85, 22607 Hamburg, Germany. ${ }^{5}$ Faculty of Mathematics, Informatics and Natural Sciences, University of Hamburg, Rothenbaumchaussee 19, 20148 Hamburg, Germany. ${ }^{6}$ Institute of Immunology, Friedrich-Loeffler Institut, Greifswald - Insel Riems, Germany. ${ }^{7}$ Faculty of Mathematics and Natural Sciences, University of Greifswald, Greifswald, Germany. ${ }^{8}$ Leibniz-Forschungsinstitut für Molekulare Pharmakologie (FMP), Robert-RössleStrasse 10, 13125 Berlin, Germany. ${ }^{9}$ Epiontis GmbH - Precision for Medicine, BarbaraMcClintock- Str. 6, 12489 Berlin, Germany. ${ }^{10}$ Microarray Core Facility, Max Planck Institute for Infection Biology, Department of Immunology, Charitéplatz 1, 10117 Berlin, Germany. ${ }^{11}$ Protein Purification Core Facility, Max Planck Institute for Infection Biology, Charitéplatz 1, 10117 Berlin, Germany. ${ }^{12}$ Institute of Functional Interfaces, Karlsruhe Institute of Technology, Karlsruhe, Germany. ${ }^{13}$ Hagler Institute for Advanced Study at Texas A\&M University, College Station, TX 7843.

*Correspondence to: pedro.mouraalves@ludwig.ox.ac.uk; kaufmann@ mpiib-berlin.mpg.de

\section{This PDF file includes:}

Materials and Methods

Figs. S1 to S11

Tables S1 to S11

References 55-86 


\section{Materials and Methods}

\section{Cells}

THP-1 (human monocytes, ATCC TIB-202) and THP-1 AhR reporter(10) cells were grown in RPMI 1640 (GIBCO), supplemented with 10\% (v/v) heat-inactivated fetal calf serum (FCS; GIBCO), $1 \%(\mathrm{v} / \mathrm{v})$ penicillin-streptomycin (GIBCO), $1 \%(\mathrm{v} / \mathrm{v})$ sodium pyruvate (GIBCO), $1 \%$ (v/v) L-glutamine (GIBCO), $1 \%$ (v/v) non-essential amino acids (GIBCO), $1 \%$ (v/v) HEPES buffer (GIBCO) and 0.05 M 2-mercaptoethanol (GIBCO). HEK293T (human embryonic kidney epithelial cells, ATCC CRL-11268), A549 cells (human type II pneumocytes, ATCC CRL-11268), A549 AhR reporter(10) and Hepa-1c1c7 (mouse hepatocytes, ATCC CRL-2026) were grown in DMEM (GIBCO), supplemented with 10\% (v/v) Fetal Calf Serum (FCS), $1 \%$ (v/v) penicillinstreptomycin, $1 \%(\mathrm{v} / \mathrm{v})$ sodium pyruvate, $1 \%(\mathrm{v} / \mathrm{v})$ L-glutamine and 1\% (v/v) HEPES buffer. All AhR reporter cell lines were kept with additional $5 \mathrm{mg} / \mathrm{mL}$ of Puromycin (Calbiochem). For CYP1A1 enzymatic activity measurements, Hepa-1c1c7 cells were kept in DMEM medium without Phenol Red (GIBCO). Cells were kept at $37^{\circ} \mathrm{C}$ in $5 \% \mathrm{CO}_{2}$. THP-1 cells were differentiated into macrophages with $200 \mathrm{nM}$ of phorbol 12-myristate 13-acetate (PMA, Calbiochem). Upon differentiation with PMA, cells were washed and kept in medium for $4 \mathrm{~d}$ before further experiments.

\section{Lentiviral production}

Lentiviruses were produced according to the described TRC lentiviral proceedings (https://www.broadinstitute.org/genome_bio/trc/publicProtocols.html). Briefly, HEK293T cells were seeded at a density of $2 \times 10^{5}$ cells $/ \mathrm{ml}$ in DMEM without antibiotics in 96 well plates. After 24h incubation, cells were transfected with lentiviral packaging mix (Sigma-Aldrich) and $100 \mathrm{ng}$ of the respective CRISPR lentiviral vector (listed in Table S6) containing pLV-U6g-EPCG vector (Sigma Aldrich), using Fugene 6 (Roche, Berlin, Germany) in Optimem medium (Gibco). After $18 \mathrm{~h}$ of incubation, medium was replaced with high serum growth medium (30\% FCS (v/v)). Viruses were harvested at $48 \mathrm{~h}$ and $72 \mathrm{~h}$ post-transfection. The lentiviral construct for the generation of AhR reporter cell lines was obtained from SABiosciences (http://www.sabiosciences.com/reporter_assay_product/HTML/CLS-9045L.html). 


\section{Lentiviral infection for CRISPR generation and AhR Reporter cells}

Lentiviral infection was performed as described previously(10) and according to the protocols available at RNAi Consortium website (https://portals.broadinstitute.org/gpp/public/). A similar protocol was used to generate the A549 CRISPR Scramble and A549 CRISPR AhR-KO or to produce the Hepa-1c1c7 AhR reporter cell line. In brief, cells were seeded at a density of $2.2 \times 10^{4}$ cells per well in a 96 well plate (NUNC). The following day, supernatants were removed and lentiviruses were added to the cells in medium containing $8 \mu \mathrm{g} / \mathrm{ml}$ of polybrene (Sigma-Aldrich). Plates were spun down for $90 \mathrm{~min}$ at $2200 \mathrm{rpm}$ at $37^{\circ} \mathrm{C}$. Transduced cells were further selected using Puromycin (Calbiochem; $5 \mathrm{mg} / \mathrm{ml}$ ) 2d after infection. For CRISPR cell lines, based on their GFP expression, cells were single cell sorted (FACSAria II, BD Biosciences) into 96 well plates and further expanded. After expansion, DNA was extracted and sequenced to verify the KO efficiency. Further validation was performed by Western blot (WB) detection.

\section{Bacterial ligands, analogues, chemicals and AhR controls}

All ligands used in this study were obtained from either academic or commercial sources, as depicted in Table S7. TCDD was provided in toluene, and solvent was exchanged to DMSO and further stored at $4^{\circ} \mathrm{C}$. All other ligands were solubilized in DMSO, and kept at RT, $4{ }^{\circ} \mathrm{C}$ or $20^{\circ} \mathrm{C}$, as mentioned in Table S7.

\section{Luciferase assay}

AhR reporter cell lines were challenged for the specified time and concentration of ligands, bacteria or bacterial culture supernatants. Afterwards, cells were harvested in reporter lysis buffer (Promega) and lysates were used to determine luciferase activity using Luciferase Assay System (Promega) according to manufacturer's instructions. Luciferase activity was normalized to the amount of protein determined by Bradford reaction (Pierce Coomassie Plus, Pierce). Results are shown as fold induction determined upon normalization to the luciferase values of the respective control.

\section{Gene expression analysis by quantitative real time PCR and fluidigm}

Total RNA was extracted using RNeasy Plus Mini kit (Qiagen) and RNA quality and concentration determined by spectrophotometry (Nanodrop 2000c, Thermo Fisher Scientific). Complementary 
DNA (cDNA) synthesis was carried out using iScript cDNA synthesis kit (Biorad) according to manufacturer's instructions. Quantitative RT-PCR (qRT-PCR) was performed using Power SYBR green Roche LightCycler® 480 Instrument II. The average threshold cycle of triplicate reactions was used for all subsequent calculations using the $\triangle \triangle \mathrm{Ct}$ method(55). Gene expression was normalized to the glyceraldehyde-3-phosphate dehydrogenase (GAPDH) or $\beta$-actin of the respective samples, for human and zebrafish, respectively. qRT-PCR data were generated from independent experiments, with 3 biological replicates per experiment. Primer and probe sequences are listed in Table S8.

Fluidigm gene expression was performed with the 96.96 Dynamic Array Integrated Fluidic Circuits from Fluidigm, as previously described(56). Preamplification of genes by reverse transcription and cDNA synthesis (18 cycles) was performed with Cells Direct one-Step qPCR kit (Life Technologies, Inc.). Gene expression was evaluated using TaqMan gene expression assay mix (Applied Biosystems) normalized to GAPDH. TaqMan probes are listed in Table S8. Data represent fold changes $(2-\Delta \Delta \mathrm{CT})$ in transcripts relative to the appropriate internal control (DMSO). qRT-PCR data were generated from technical replicates from at least 5 independent experiments.

\section{Ethoxyresorufin-O-deethylase (EROD) activity in hepatocytes}

The EROD assay was used to detect the CYP1A1 enzymatic activity in Hepa-1c1c7 cells by measuring the conversion of ethoxyresorufin to resorufin(57). Briefly after stimulation of the cells with the diverse ligands, $4 \mu \mathrm{M}$ resorufin ethyl ether (EROD, Sigma-Aldrich) and $10 \mu \mathrm{M}$ dicoumarol (Sigma-Aldrich) were added to cell culture for $1 \mathrm{~h}$, followed by measuring the relative fluorescence of resorufin using a TECAN Infinite M200 pro plate reader (TECAN). The activity was corrected to the amount of protein, measured by Bradford reaction (Pierce Coomassie Plus, Pierce), and normalized to the respective control as mentioned in each figure legend.

\section{Lactate dehydrogenase (LDH) assay}

LDH was determined using the Cytotoxicity Detection Kit Plus (Roche) according to the manufacturer's instruction. Percentage (\%) of cytotoxicity was calculated as:

$$
\text { Cytotoxicity }(\%)=\frac{\text { experimental value-low control }}{\text { high control-low control }} \times 100
$$




\section{Percentage of infection and Caspases $3 / 7$ positive cell determination}

Caspase activity was determined using the Cell Event Caspase 3/7 Green detection reagent (Thermo Fisher Scientific) according to manufacturer's protocol. In brief, after different stimulations, cell nucleus was labelled using NucRed Live 647 Ready probes (Thermo Fisher Scientific). Cells were then labelled with the Caspase 3/7 Green detection reagent for 30 min and images were acquired in an Array Scan TM XTI Live High Content Platform (Thermo Fisher Scientific). After acquisition, nuclear labelling was used to identify cells and green fluorescence spots were used to determine caspase $3 / 7$ positive cells.

A similar approach was used to determine the percentage of infected cells. In short, nuclear staining was used to identify the cell and green fluorescence spots of bacteria (PA14-GFP) to assign infected cells.

\section{Western blot}

Cell lysates were prepared using RIPA buffer (Cell Signaling technology) containing Complete protease inhibitor cocktail (Roche). Lysates were boiled at $95^{\circ} \mathrm{C}$ for $10 \mathrm{~min}$ in presence of Sample Buffer (Biorad), loaded in Mini-protean TGX precast Polyacrylamide gels (Biorad) and further transferred into nitrocellulose membranes (Biorad). Protein expression was detected upon incubation with specific antibodies for each protein (Table S9), and visualized using SuperSignal West Pico Plus (Thermo Fisher Scientific) on a ChemiDoc Imaging System (Biorad).

\section{Pyo determination by spectrophotometry}

Pyo concentration was determined by spectrophotometry as previously described $(10,41,43)$. Briefly, optical density at $690 \mathrm{~nm}$ (OD $690 \mathrm{~nm}$ ) was measured and the relative Pyo concentrations were determined by comparison with a Pyo standard curve. Concentrations of secreted Pyo from different bacteria were measured after filtration of supernatants using $0.22 \mu \mathrm{m}$ Spin-X centrifuge tube filters (Corning). Concentrations of Pyo in the water from Zebrafish larvae infection studies were determined directly in the water collected at the indicated time points after infection with different strains and growth conditions of P.aeruginosa. 


\section{QS molecules determination by HPLC}

P.aeruginosa culture supernatants $(2 \mathrm{~mL})$ were extracted two times with Ethylacetate/0.5\% (v/v) acetic acid. The organic phases (containing phenazines, quinolones and homoserine lactones) were evaporated, extracts dissolved in methanol $(100 \mu \mathrm{L})$ and centrifuged for $5 \mathrm{~min}$ at $10000 \mathrm{~g}$ to remove insoluble material. Under these conditions, Pyo was extracted into the aqueous phase, which was lyophilized and further dissolved in $2 \mathrm{~mL}$ chloroform/methanol (2:1) and $1 \mathrm{~mL}$ water. The Pyo containing chloroform phase was acidified with $10 \mu \mathrm{L}$ of $1 \mathrm{~N} \mathrm{HCl}$ and extracted with 1 $\mathrm{mL}$ of methanol/water (1:1). The aqueous upper phase was dried by rotary evaporation and dissolved in $200 \mu \mathrm{L}$ methanol and $4 \mu \mathrm{l}$ of these extracts were loaded onto a Waters Acquity UPLCcolumn $(2.1 \times 100 \mathrm{~mm}$ HSS C18, $1.8 \mu \mathrm{m})$. Compounds were eluted with a linear gradient from $20 \%$ acetonitrile to $100 \%$ acetonitrile containing $10 \mathrm{mM}$ ammonium acetate, $\mathrm{pH} 5.5$ at $45^{\circ} \mathrm{C}$ at a flow rate of $0.5 \mathrm{ml} / \mathrm{min}$ within $6 \mathrm{~min}$. Phenazines were detected and identified by UV/Vis (Waters PDA Detector) and ESI-MS (Waters QDa detector). The QDa detector was operated in an electrospray positive ion mode by applying a voltage of $0.8 \mathrm{kV}$. The cone voltage was set at $15 \mathrm{~V}$. The probe temperature was set at $600{ }^{\circ} \mathrm{C}$. A full mass spectrum between m/z 100 and 1000 was acquired at a sampling rate of 2.0 points/sec: 1-HP: Molecular weight: 196.2, m/z found for [M+H]+: 197.1; PCA: Molecular weight: 224.4, m/z found for $[\mathrm{M}+\mathrm{H}]+: 225.2 ; \mathrm{PCN}$ : Molecular weight: 223.2, m/z found for $[\mathrm{M}+\mathrm{H}]+:$ 224.1; Pyo: Molecular weight: $210.2, \mathrm{~m} / \mathrm{z}$ found for $[\mathrm{M}+\mathrm{H}]+:$ 211.3. Quantification of phenazines was performed by integration of the UV-absorbance peaks at $370 \mathrm{~nm}$ and $330 \mathrm{~nm}$. A five point calibration from 1 to $200 \mathrm{pmol}$ of the standard compounds was prepared for the quantification.

\section{LC-MS/MS analysis for target quantification}

Mass spectrometric (MS) analysis was performed using an API 4000TM quadrupole mass spectrometer (Applied Biosystems / MDS Sciex Toronto, Canada), equipped with an electro spray ionization (ESI) source. MS spectra were generated by infusion experiments using a syringe pump (Harvard Apparatus Inc. South Natick, MA, USA). Single MS experiments (Q1-scan) and MS/MS experiments (product ion scan, PIS) were used to retrieve structural information. Nitrogen 5.0 was used as curtain gas, nebulizer gas and collision gas. The standard compounds of 3-o-C12-HSL, C4-HSL and HHQ were diluted in a solvent mixture of acetonitrile/0.1\% acetic acid (50:50, v/v) and infused with a flow rate of $0.80 \mathrm{ml} / \mathrm{h}$. MS experiments were carried out in the positive 
ionization mode using an ion spray voltage (IS) of $4800 \mathrm{~V}$, a declustering potential (DP) of $30 \mathrm{~V}$ and an entrance potential (EP) of $10 \mathrm{~V}$. MS/MS experiments were generated using the compound optimization mode in the software Analyst V 1.6. For all targets, three mass transitions (one quantifier and two qualifiers) were selected (Table 1).

Table 1-LC-MS/MS analysis of 3-o-C12-L-HSL, C4-L-HSL and HHQ.

\begin{tabular}{|c|c|c|c|c|}
\hline $\begin{array}{c}\text { Target } \\
\text { compound }\end{array}$ & $\begin{array}{c}\mathrm{Mw} \\
{[\mathrm{g} / \mathrm{mol}]}\end{array}$ & $\begin{array}{c}\mathrm{m} / \mathrm{z} \\
\text { Quantifier }\end{array}$ & $\begin{array}{c}\mathrm{m} / \mathrm{z} \\
\text { Qualifier 1 }\end{array}$ & $\begin{array}{c}\mathrm{m} / \mathrm{z} \\
\text { Qualifier 2 }\end{array}$ \\
\hline 3-o-C12-L-HSL & 297.39 & $298.2 / 102.2$ & $298.2 / 197.2$ & $298.2 / 74.1$ \\
\hline C4-L-HSL & 171.20 & $172.1 / 102.1$ & $172.1 / 71.0$ & $172.1 / 43.1$ \\
\hline HHQ & 243.34 & $244.0 / 159.0$ & $244.0 / 172.0$ & $244.0 / 130.0$ \\
\hline
\end{tabular}

An Agilent 1100 HPLC system (Agilent Waldbronn, Germany) was used for sample separation on a Nucleosil-C4 120A, 5 $\mu \mathrm{m}$ column $(100 \times 4 \mathrm{~mm})$. A gradient of acetonitrile and $0.1 \%$ acetic acid (Table 2) was used by a total run time of $30 \mathrm{~min}$. The ion source temperature was set to $400^{\circ} \mathrm{C}$ and a flow rate of $500 \mu \mathrm{L} / \mathrm{min}$ was applied. The injection volume for all samples was $20 \mu \mathrm{L}$. A fivepoint calibration from 0 to $50 \mathrm{ng} / \mathrm{mL}$ was prepared for quantification of the extracted targets.

Table 2-Acetonitrile and acetic acid gradient

\begin{tabular}{|c|c|c|}
\hline Time, $\min$ & Flow, $\mu \mathrm{L} / \mathrm{min}$ & Acetonitrile Concentration, $\%$ \\
\hline 0.00 & 500 & 50 \\
\hline 2.00 & 500 & 50 \\
\hline 8.00 & 500 & 90 \\
\hline 15.00 & 500 & 90 \\
\hline 16.00 & 500 & 50 \\
\hline 30.00 & 500 & 50 \\
\hline
\end{tabular}

For the quantification of PQS, a separate UPLC-MS/MS method was developed. An Exion UPLC system (AB Sciex, Toronto, Canada) was used for sample separation on a Kinetex XB-C18 100A, $2.6 \mu \mathrm{m}(100 \times 2.1 \mathrm{~mm})$ at $45^{\circ} \mathrm{C}$. A gradient (Table 3) of acetonitrile/water 95:5 v/v $+0.1 \%$ formic acid and water containing $2 \mathrm{mM}$ picolinic acid $+0.1 \%$ formic acid was used, at a total run time of $3.40 \mathrm{~min}$. The ion source temperature was set to $600^{\circ} \mathrm{C}$ and a flow rate of 900 to $1000 \mu \mathrm{L} / \mathrm{min}$ was applied. The injection volume for all samples was $4 \mu \mathrm{L}$. A five-point calibration from 1 to $50 \mathrm{ng} / \mathrm{mL}$ was prepared for quantification of the extracted targets. 
Table 3 -Gradient used for PQS determination.

\begin{tabular}{|c|c|c|}
\hline $\begin{array}{c}\text { Time, } \\
\mathrm{min}\end{array}$ & $\begin{array}{c}\text { Flow, } \\
\mu \mathrm{L} / \mathrm{min}\end{array}$ & $\begin{array}{c}\text { Acetonitrile/water } 95: 5 \mathrm{v} / \mathrm{v}+0.1 \% \\
\text { formic acid concentration, \% }\end{array}$ \\
\hline 0.00 & 900 & 85.0 \\
\hline 0.05 & 900 & 85.0 \\
\hline 0.30 & 900 & 77.5 \\
\hline 1.90 & 1000 & 45.0 \\
\hline 2.20 & 1000 & 10.0 \\
\hline 2.35 & 1000 & 10.0 \\
\hline 2.45 & 900 & 85.0 \\
\hline 3.40 & 900 & 85.0 \\
\hline
\end{tabular}

For PQS, three mass transitions (one quantifier and two qualifiers) were selected (Table 4).

Table 4 LC-MS/MS analysis of PQS.

\begin{tabular}{|c|c|c|c|c|}
\hline $\begin{array}{c}\text { Target } \\
\text { compound }\end{array}$ & $\begin{array}{c}\mathrm{Mw} \\
{[\mathrm{g} / \mathrm{mol}]}\end{array}$ & $\begin{array}{c}\mathrm{m} / \mathrm{z} \\
\text { Quantifier }\end{array}$ & $\begin{array}{c}\mathrm{m} / \mathrm{z} \\
\text { Qualifier 1 }\end{array}$ & $\begin{array}{c}\mathrm{m} / \mathrm{z} \\
\text { Qualifier 2 }\end{array}$ \\
\hline $\mathrm{PQS}$ & 259.34 & $260.2 / 174.9$ & $260.2 / 146.4$ & $260.2 / 188.2$ \\
\hline
\end{tabular}

\section{QS molecules determination using bacterial reporter strains}

The expression of 3-o-C12-L-HSL and HHQ was determined using the PA14-R3 and PAO1 pqsA CTX-lux::pqsA bacteria reporters, respectively, and according to established protocols $(27,28)$. In short, PA14-R3 was streaked on LB plates, and colonies were further picked to inoculate LB medium. After overnight incubation $\left(220 \mathrm{RPM}, 37^{\circ} \mathrm{C}\right)$, the bacterial culture was further diluted in $\mathrm{LB}$ and re-grown for $2 \mathrm{~h}$. Optical density (OD600 $\mathrm{nm}$ ) was determined and culture was diluted to OD600 $=0.045$, in LB containing $50 \mathrm{mM}$ of MOPS (Sigma). Diluted bacterial culture $(180 \mu \mathrm{L})$ was transferred into transparent bottom 96 well black plates (Corning), and $20 \mu \mathrm{L}$ of the positive control (3-o-C12-L-HSL at diverse concentrations) or the samples were added. The plate was incubated for $4 \mathrm{~h}\left(100 \mathrm{RPM}, 37^{\circ} \mathrm{C}\right)$ and further assayed for bioluminescence and OD600 in a TECAN200. Similarly, PAO1 pqsA CTX-lux::pqsA colonies were incubated overnight (220 RPM, $37^{\circ} \mathrm{C}$ ) in LB containing $125 \mu \mathrm{g} / \mathrm{mL}$ tetracycline. After further dilution and $2 \mathrm{~h}$ incubation (220 $\mathrm{RPM}, 37^{\circ} \mathrm{C}$ ), OD600 was adjusted to 1 in $\mathrm{LB}$ containing the antibiotic. A dilution of 1:50 or 1:100 of the culture was placed in a transparent bottom 96 well black plate (Corning) and $100 \mu \mathrm{L}$ of the positive control (HHQ at diverse concentrations) or the samples were added. The plate was incubated at $37^{\circ} \mathrm{C}(120 \mathrm{RPM})$ and bioluminescence and optical densities (OD600) were determined every $30 \mathrm{~min}$. In both cases, luminescence values were normalized per cell density. 


\section{Degradation assays}

In the 3-o-C12-L-HSL and HHQ degradation assays, A549 CRISPR Scramble and A549 CRISPR AhR-KO cells were stimulated with the respective QS molecule, and supernatants collected at different time points. The cell free supernatants were used to stimulate bacterial QS reporters, PA14-R3 and PAO1 pqsA CTX-lux::pqsA for the detection of 3-o-C12-L-HSL and HHQ, respectively. Simultaneous experiments were performed under conditions without cells to determine the natural decay of each compound in the cell medium. Relative QS levels were determined by comparison with the bioluminescence detected in the 'input' (i.e., cell medium containing the initial QS concentration used to stimulate the cells). HPLC experiments were performed using the protocol described above.

\section{Microarray hybridization}

Total RNA was isolated with Trizol (Invitrogen) following the manufacturer's protocol using glycogen as co-precipitant. Quality control and quantification of total RNA was analysed using an Agilent 2100 Bioanalyzer (Agilent Technologies) and a NanoDrop 1000 UV-Vis spectrophotometer (Thermo Fisher Scientific). Microarray experiments were performed as singlecolor hybridization. Total RNA was amplified and labelled with the low input Quick-Amp Labeling Kit (Agilent Technologies). In brief, mRNA was reverse transcribed and amplified using an oligo-dT-T7 promoter primer and labelled with cyanine 3-CTP. After precipitation, purification, and quantification, $0.75 \mu \mathrm{g}$ labelled cRNA was fragmented and hybridized to custom whole genome human $8 \times 60 \mathrm{~K}$ multipack microarrays (Agilent-048908) or 1.25 $\mu \mathrm{g}$ labelled cRNA was fragmented and hybridized to catalogue $4 \mathrm{x} 44 \mathrm{~K}$ Zebrafish (v3) gene expression microarrays (Agilent-026437) according to the supplier's protocol (Agilent Technologies). Scanning of microarrays was performed with either $3 \mu \mathrm{m}$ resolution $(8 \times 60 \mathrm{~K})$ or extended dynamic range (XDR) and $5 \mu \mathrm{m}$ resolution $(4 \mathrm{x} 44 \mathrm{~K})$ using a G2565CA high-resolution laser microarray scanner (Agilent Technologies). Microarray image data were processed with the Image Analysis/Feature Extraction software G2567AA v. A.11.5.1.1 (Agilent Technologies) using default settings and the GE1_1105_Oct12 extraction protocol. The extracted .txt files were further analysed using R and the associated BioConductor limma package(58). Microarray data have been deposited in the Gene Expression Omnibus (GEO; www.ncbi.nlm.nih.gov/geo/) of the National Center for Biotechnology Information and can be assessed with the GEO accession number GSE121101. 


\section{Microarray analysis}

For differential gene expression analysis, the limma $\mathrm{R}$ package(58) was used. Contrasts were defined for comparison between each experimental condition and treatment with DMSO. In infection experiments, results were compared to non-infection controls. For comparison between treatments, the interaction between treatment (1-HP, 1-HP+3-o-C12-L-HSL, 3-o-C12-L-HSL or DMSO) and the experimental conditions in the presence or absence of $\mathrm{CH} 223191$ was tested.

Gene set enrichment analysis was performed using the tmod R package(59). Genes were ordered by the gene expression effect size metrics $\operatorname{MSD}(60)$. A custom gene set was defined for the xenobiotic metabolism based on current literature (Table S11) and enrichment was tested using the CERNO algorithm and the predefined module.

\section{Homology modelling}

A BLAST search with the sequence of hAhR PASB as a template revealed 58 hits in the Protein Data Bank (PDB) of experimental crystal structures. Based on sequence alignment, similarities as well as bound ligands of 7 crystal structures were selected for a multiple sequence alignment. This was then used to build a multiple template based homology model of hAhR PASB. X-ray complexes (PDB ID): 3F1O, 4F3L, 4GHI, 4GS9, 4H6J, 5TBM (chain A) and 4ZPR (chain B) were downloaded from the PDB and the respective chains were isolated. Modeller 9.17(61) was used to create the multiple template based homology model of hAhR. The resulting models were ranked by DOPE scoring(62). The best scoring model was selected for subsequent modelling activities. Then, model quality was checked and the Protein Preparation wizard included in Maestro11 software (Schrödinger, LLC, New York, NY, 2017) was used to adjust structural defects using default values. All ligands were downloaded from Pubchem and thereafter analysed by the Ligand Preparation Wizard to correct improper connectivity.

\section{Docking studies}

Molecular docking was carried out using Glide included in Maestro 11v0 software(63) (https://www.schrodinger.com/maestro). Glide docking methodologies use a series of hierarchical filters searching for possible ligand positions in the receptor binding-site. The first step in molecular docking via Maestro11v0 is to set up the receptor grid defining shape and properties of the receptor binding site, important for scoring the ligand poses in a later step. Ligand flexibility 
is accounted for by exhaustive sampling of ligand torsions during the docking process. Suitable poses are selected in a next step for further refinement of torsional space in the field of the receptor. Finally, in a post-docking minimization the selected poses are minimized with full ligand flexibility. The docking results are ranked by GlideScore, an empirical scoring function yielding an estimate of the binding affinity and designed to maximize separation of compounds with strong binding affinity from those with low to no binding ability(63).

The receptor grid for the hAhR homology models was set up using default parameters. Flexible ligand docking was carried out in standard precision (SP). The Molecular Mechanics-Generalized Born Surface Area application MM-GBSA was used for rescoring the docking poses. MM-GBSA binding energies $\left(\Delta \mathrm{G}^{\mathrm{Bind}}\right)$ are approximate free binding energies of protein-ligand complexes, with a more negative value indicating stronger binding.

\section{AhR binding studies - Radioactive labelled TCDD competition}

Radioligand experiments were performed as described previously (10). In brief, livers from wild type (WT) and AhR knockout $\left(\mathrm{AhR}^{--}\right.$) mice were collected and minced in 3-fold (w/v) MDEG buffer (25 mM MOPS, 1 mM DTT, 1 mM EDTA and $10 \%$ Glycerol, pH 7.5). Lysates were further homogenized using gentleMacs (Miltenyi), and subsequently ultracentrifuged at $100000 \mathrm{~g}$ for $1 \mathrm{~h}$. Cytosolic fraction was collected, protein concentration determined by Bradford reaction (Protein Assay Kit, Pierce) and further diluted to final concentration of $5 \mathrm{mg}$ of cytosol protein $/ \mathrm{mL}$ in MDEG buffer. The entire procedure was carried out at $4^{\circ} \mathrm{C}$. Binding studies were performed by incubating the extracts $48 \mathrm{~h}$ at $4^{\circ} \mathrm{C}$ with $\left[{ }^{3} \mathrm{H}\right]$ TCDD and with or without an excess of unlabelled TCDD. After incubation, $30 \mu \mathrm{L}$ of a charcoal Norit A suspension $(100 \mathrm{mg} / \mathrm{mL}$ in previously prepared MDEG buffer) was added into $200 \mu 1$ of the reaction mixture and incubated on ice for 15 min. Following centrifugation at $25000 \mathrm{~g}$ for $15 \mathrm{~min}$ at $4^{\circ} \mathrm{C}, 130 \mu \mathrm{L}$ of the supernatant was removed and radioactivity was measured in a scintillation counter (Tri-Carb 3110TR, PerkinElmer). Specific binding was defined as the difference of radioactivity between AhRproficient and AhR-deficient extracts. For competition assays, serial dilutions of competitor molecules (3-o-C12-L-HSL, C4-L-HSL, HHQ and PQS) were incubated together with [ $\left.{ }^{3} \mathrm{H}\right] \mathrm{TCDD}$ and the corresponding IC50 values determined. Bmax and $\mathrm{K}_{\mathrm{d}}$ were calculated by nonlinear regression (GraphPad Prism version 7.0, San Diego, CA), fitting a saturation isotherm. IC50 values 
were obtained by fitting a one-site competitive binding equation to the experimental data. $\mathrm{K}_{\mathrm{i}}$ values were derived from IC50 using the Cheng-Prusoff equation.

\section{AhR binding studies - Microscale Thermophoresis (MST)}

A codon-optimized fragment of the human AhR encoding amino acid residues 23-475 was commercially synthesized (MWG Eurofins) and cloned into pET21b (Novagen). The pET30EK/LIC-mARNT expression plasmid encoding the murine ARNT (residues 85-465) was a kind gift from Prof. Oliver Daumke (MDC Berlin). For protein expression, BL21(DE3) cells were cotransformed with both plasmids. Bacteria were grown in LB medium and expression was induced at an OD600 of 0.6 with $0.5 \mathrm{mM}$ isopropyl- $\beta$-D-thiogalactopyranoside (IPTG), followed by an incubation over night at $16^{\circ} \mathrm{C}$. Proteins were purified as previously described for other bHLH-PAS proteins(64). Briefly, cell pellets were resuspended in lysis buffer containing DNaseI (Serva) and Complete Protein Inhibitor Cocktail (Roche) and lysed using a French Cell Press. The clarified lysate was applied onto a HisTALON ${ }^{\mathrm{TM}}$ Superflow ${ }^{\mathrm{TM}}$ column (Clontech) and bound protein eluted with $300 \mathrm{mM}$ imidazole. N-terminal 6xHis-tag was cleaved off with PreScission protease at $4^{\circ} \mathrm{C}$. The protein complex was further purified on a HiTrap Heparin HP column (GE Healthcare), followed by SEC on a Superdex 200 10/300 GL equilibrated in 20 mM HEPES pH 8.0, 300 mM $\mathrm{NaCl}, 5 \%$ glycerol, and $5 \mathrm{mM}$ DTT. Peak fractions containing the AhR-Arnt complex were pooled and concentrated using Amicon filter units (Millipore). Binding of ligands to the AhR-Arnt complex was assessed by microscale thermophoresis (MST) experiments using the Monolith® NT.LabelFree (NanoTemper Technologies GmbH). MST measurements were performed according to the manufacturer's instructions. In brief, a constant protein concentration of $250 \mathrm{nM}$ (final) diluted in assay buffer including $0.1 \%$ Pluronic F-127 was used. After a short incubation at RT, the samples were centrifuged for $5 \mathrm{~min}$ at 16000xg to remove large aggregates and filled into NT. LabelFree Zero Background MST Premium coated capillaries (NanoTemper Technologies $\mathrm{GmbH}$ ). Measurements were carried out at $22^{\circ} \mathrm{C}$. MST traces were collected with an LED excitation power of $20 \%$ and a MST laser power of 20 or $40 \%$. For analysing the interaction affinity, the dissociation constant $\mathrm{K}_{\mathrm{d}}$ for each ligand was calculated using the NanoTemper Analysis software by the changes in the normalized fluorescence $(\Delta$ Fnorm $[\%]$ ) versus the ligand concentration. 


\section{Zebrafish handling}

Zebrafish and embryos were raised and maintained according to standard protocols(65). Experiments at the MPIIB were approved by and conducted in accordance with the guidelines set out by the State Agency for Health and Social Affairs (LaGeSo, Berlin, Germany).

Fertilized embryos were used for all experiments and kept in Embryo medium(65) (E3, $5 \mathrm{mM}$ $\mathrm{NaCl}, 0.17 \mathrm{mM} \mathrm{KCl}, 0.33 \mathrm{mM} \mathrm{CaCl}_{2}, 0.33 \mathrm{mM} \mathrm{MgSO}_{4}$ ) in an incubator at $28^{\circ} \mathrm{C}$. Of note, 0.00001 $\%$ Methylene Blue was added to the E3 in experiments not involving microscopy. In all experiments, 1dpf larvae were manually dechorionated under a Leica MZ6 Stereomicroscope or using Pronase (Sigma), following approved protocols(65). At 2dpf, zebrafish larvae were divided into the different experimental groups, at a density of 12 larvae per well of a 12 well plate (Corning) in $1.5 \mathrm{~mL}$ of E3, unless stated otherwise.

\section{Zebrafish larva exposure and infection experiments}

In the larva exposure experiments, $2 \mathrm{dpf} \mathrm{AB}$ strain larvae were exposed to the different ligands in water at $28{ }^{\circ} \mathrm{C}$ at the indicated time points. In experiments using the AhR inhibitor $\mathrm{CH} 223191$ (SIGMA), larvae were pre-exposed to $5 \mathrm{uM}$ of the inhibitor for $2 \mathrm{~h}$ prior to the start of the experiment and the inhibitor was kept during the experiment. In the infection by immersion experiments, $2 \mathrm{dpf}$ larvae were placed in water containing the different conditions of P.aeruginosa, containing the indicated CFU and bacterial growth conditions, and kept in the incubator at $28^{\circ} \mathrm{C}$ for the indicated time points.

\section{Zebrafish larva gene expression analysis}

After the desired exposure to diverse ligands or infections, larvae were euthanized with Tricaine (MS-222, $300 \mu \mathrm{g} / \mathrm{mL}$ SIGMA) and placed in Trizol for RNA isolation. Further qRTPCR experiments were performed using Syber-green primers (Eurofins) listed in Table S8.

\section{Zebrafish larva CYP1A enzymatic activity (EROD) and toxicity assessment}

The EROD experiments were performed as described previously(66). Upon Cyp1a activation, nonfluorescent 7-ethoxyresorufin diffuses into the embryo and is O-deethylated into resorufin, a fluorescent product that can be measured(66). In brief, after P.aeruginosa or ligand exposure, 2dpf zebrafish larvae were washed and placed in medium containing $0.4 \mu \mathrm{g} / \mathrm{mL}$ of 7 -ethoxyresorufin 
(Cayman Chemical) for 5 min. Further, larvae were anesthetized with Tricaine (MS-222 168 $\mu \mathrm{g} / \mathrm{mL}$ SIGMA), placed in black 96 well plates with clear bottom (Thermo Fisher Scientific) and imaged in an Array Scan TM XTI Live High Content Platform (Thermo Fisher Scientific). Brightfield images were used to identify the shape of the larvae and fluorescence (filters excitation: 549/15 nm, emission: 590-624 nm) was determined per larva as readout of CYP1A activation. Head-to-tail distances and straightness of individual larvae were determined to assess toxicity, using the Array Scan TM XTI Live High Content Platform (Thermo Fisher Scientific) software.

\section{Zebrafish larva WB lysate preparation}

Zebrafish larvae WB lysates were prepared as previously described(67). In brief, larvae were euthanized with Tricaine (MS-222, $300 \mu \mathrm{g} / \mathrm{mL}$ SIGMA) and kept on ice for 5 min. Deyolking was performed using $200 \mu \mathrm{L}$ of deyolking buffer $(55 \mathrm{mM} \mathrm{NaCl}, 1.8 \mathrm{mM} \mathrm{KCl}, 1.25 \mathrm{mM} \mathrm{NaHCO} 3$ and Complete protease inhibitor cocktail (Roche)) and shaking for 5 min to dissolve the yolk. Samples were centrifuged for $30 \mathrm{sec}$, supernatants were discarded and pellets resuspended in $200 \mu \mathrm{L}$ of RIPA buffer (Cell Signaling technology). After sonication, lysates were stored at $-20^{\circ} \mathrm{C}$ until further use.

\section{Zebrafish XRE determination}

Promoter analysis to determine possible Xenobiotic Response Elements (XRE) was performed as previously described(40). In short, sequences of the different zebrafish genes, including the regions 0-5000 bp upstream of the untranslated region (UTR) and the UTRs (to include introns upstream of the start codon), were downloaded from Pubmed. Putative XRE were determined by identifying the consensus motifs, 5'-T/GNGCGTG-3'or its reverse complement, along the different sequences.

\section{Mice handling}

AhR-deficient mice ( $A h R^{-/}, \mathrm{C} 57 \mathrm{BL} / 6$ background) were kindly provided by B. Stockinger (MRC, National Institute for Medical Research, London, UK). C57BL/6 (WT) and $A h R^{-l-}$ mice were bred in the Max Planck Institute for Infection Biology mouse facility. Mice were 8-12 weeks of age at the beginning of the experiments, matched for age and sex, and kept under specific pathogen-free conditions. Animal experiments were carried out according to institutional guidelines approved by 
the local ethics committee of the German authorities (LaGeSo; Landesamtes für Verbraucherschutz und Lebensmittelsicherheit, project number G0257/12).

\section{Mouse infection}

Age- and gender-matched mice (all C57BL/6 background) were intratracheally infected with $2 \times 10^{6}$ CFU for P.aeruginosa PA14 (WT, 09480 and $\Delta r s a L$ ) under light anaesthesia. Bacteria inoculum was streaked on LB agar plates for CFU enumeration. After $8 \mathrm{~h}$ of infection, mice were sacrificed by cervical dislocation and the lungs were dissected and mechanically disrupted manually or using gentleMACS tubes (Miltenyi Biotec) in a gentleMACS Dissociator (Miltenyi Biotec), following manufacturer's instructions. Lung homogenates were plated on LB agar plates for $\mathrm{CFU}$ enumeration or stored at $-20^{\circ} \mathrm{C}$ for further Bioplex analysis.

\section{Flow cytometry analysis of mouse neutrophils}

Mice were sacrificed by cervical dislocation. The lungs were dissected, placed into wells of a 6well plate, diced into $1 \mathrm{~mm}$ pieces with scissors and incubated with collagenase and DNAse for $30 \mathrm{~min}$ at $37^{\circ} \mathrm{C}$. The tissue was then gently forced through a $70 \mu \mathrm{m}$ mesh and rinsed twice with complete medium. The cells were pelleted, and following lysis of red blood cells and another wash with medium, the cells were resuspended in Fc block and subsequently stained for flow cytometry (FACS). Following the staining, cells were washed in FACS buffer (PBS $+1 \%$ FCS) and resuspended in a Propidium Iodide (PI) solution. The gating strategy used to quantify neutrophils was as follows: single cells, $\mathrm{CD}_{4}{ }^{+} \mathrm{PI}^{-}$, Siglec $\mathrm{F}^{-} \mathrm{CD} 11 \mathrm{c}^{-}, \mathrm{Ly}^{+} \mathrm{G}^{+} \mathrm{CD} 11 \mathrm{~b}^{+}$. The antibodies used for the FACS analysis are listed in Table S9.

\section{Bacterial growth conditions and preparation}

P.aeruginosa strains, listed in Table S10, were streaked on LB plates and incubated overnight at $37^{\circ} \mathrm{C}$. The following day, 8 individual colonies of each strain were grown in liquid LB medium at $37^{\circ} \mathrm{C}$ overnight, shaking at 220 RPM. Cultures from the same bacterial strains were mixed and serial dilutions were made in order to reach the desired OD600 after $2 \mathrm{~h}$ of further incubation $\left(37^{\circ} \mathrm{C}\right.$, 220 RPM). Once the desired OD was reached, bacteria were spun and culture supernatants were filtered twice using $0.22 \mu \mathrm{m}$ Spin-X centrifuge tube filters (Corning). The concentrations of different QS molecules were determined, as described above, and the supernatants stored at $4{ }^{\circ} \mathrm{C}$ 
or $-20^{\circ} \mathrm{C}$, depending on the following experiment. Pelleted bacteria were washed twice with PBS, passed 10 times through a syringe to obtain single colonies and the inocula prepared for further infection experiments according to the desired CFU. Inocula were streaked on LB plates for CFU enumeration.

\section{In vitro infection and bacterial supernatant stimulation}

For in vitro infection experiments, cells were infected with the different P.aeruginosa strains and gentamycin was added to the culture after $1 \mathrm{~h}$ infection, to control extracellular bacterial growth(10). The filtered supernatants of P.aeruginosa were diluted in cell growth medium (DMEM or RPMI) and further used to stimulate the AhR reporter cell lines.

\section{Statistical analysis}

For in vivo experiments, animals were randomly assigned to the different experimental groups and group size was chosen to allow a significance threshold $\alpha$ of 0.05 with a power of $80 \%(\beta=0.2)$. For in vitro studies, cells were randomly distributed in different culture well plate positions. Data are presented as mean+/-SD (for presentation of individual experiments, where $\mathrm{n}=$ number of biological replicates) or mean+/-SEM (for presentation of pooled experiments, where $n=$ number of independent experiments), as mentioned in figure legends. Each individual experiment was performed with technical and/or biological replicates. Pooled experiments depict mean values of independent experiments. To compute $\mathrm{P}$ values, depending on sample distribution and variation, different tests were performed, as described in figure legends. Two-tailed Student's t-test or MannWhitney U-test were used to compare data from two groups and one-way or two-way ANOVA (randomized block design) to compare data from three or more groups. GraphPad Prism version 7.0 was used for analysis and differences were considered statistically significant at $\mathrm{P}<0.05$. 

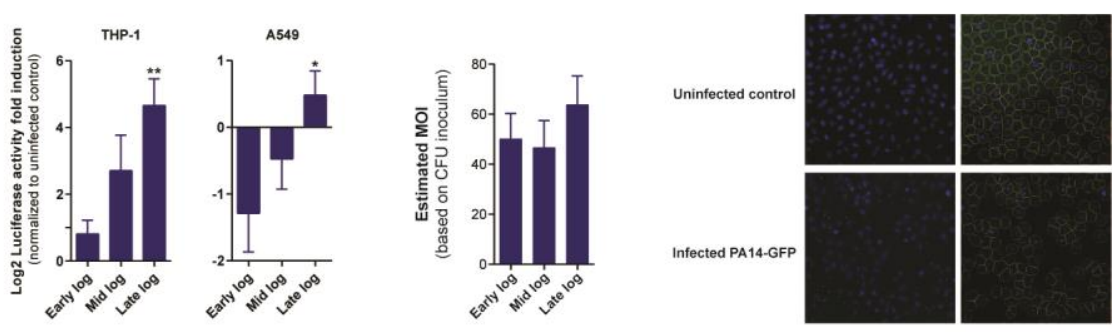

D

E

F
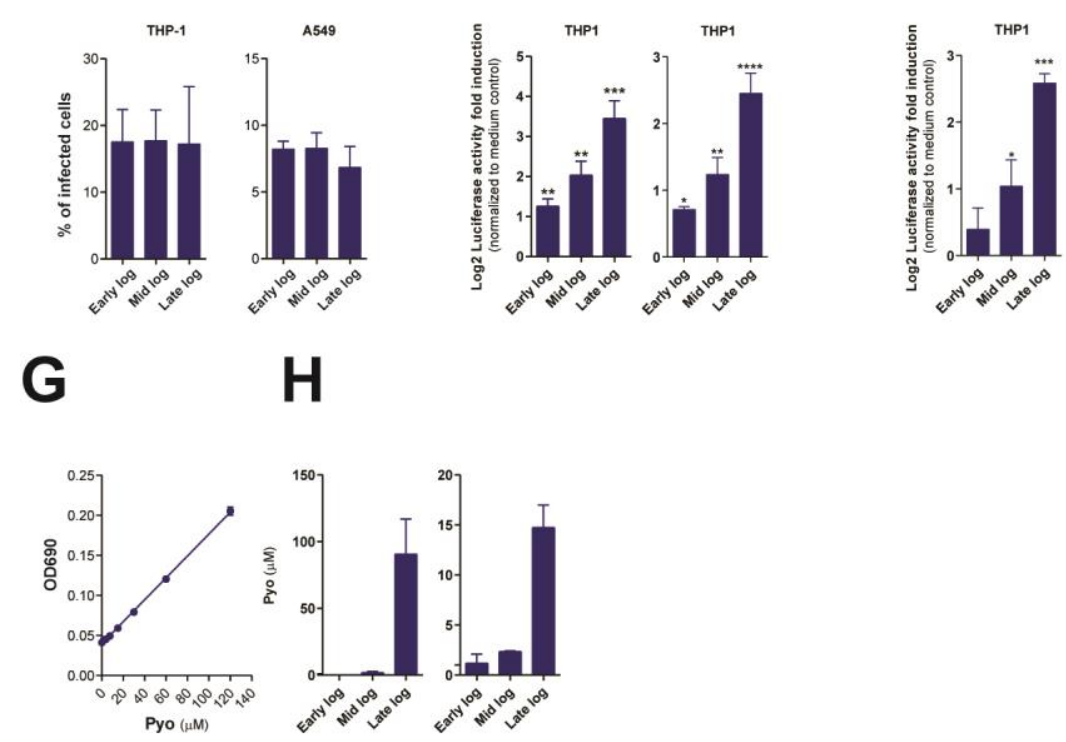

Fig. S1. P.aeruginosa in vitro infection and Pyo expression kinetics. (A) Luciferase activity of AhR reporter THP-1 and A549 cells upon 24h infection with P.aeruginosa PA14-WT strain grown in DMEM medium, at a multiplicity of infection (MOI) 50 (THP-1 ( $n=6)$ or A549 (n=3) independent experiments). (B) Multiplicity of infection (MOI) of in vitro infected cells ( $\mathrm{n}=5$ independent experiments). (C,D) Cells were infected for $1 \mathrm{~h}$ with PA14-WT strain expressing GFP (PA14-WT-GFP) collected from different growth phases. (C) Representative images of A549 infected and non-infected cells. Nuclei depicted in blue and cell shape in yellow lines. Green dots (left) and Red dots (right) represent bacterial spots, total and localized within cell area, respectively. (D) Quantification of infected cells (THP-1 ( $n=2)$ or A549 ( $n=4)$ independent experiments). (E,F) THP-1 AhR reporter stimulation with filtered supernatants (1:25 diluted) from PA14 WT (E left, $n=6$ independent experiments), PA14 WT-GFP (E right, $n=3$ independent experiments) or PAO1 (F, n=3 independent experiments), collected from different bacterial growth phases in DMEM medium. $(\mathbf{G}, \mathbf{H})$ Pyo concentration determined by spectrophotometry. (G) Standard curve (1 representative experiment out of at least 3 independent experiments) and (H) Pyo concentrations in supernatants of PA14-WT grown in LB (left, n=5 independent experiments) or DMEM medium (right, $n=9$ independent experiments), collected from different 
bacterial growth phases. (A,B,D,E,F, H) Means +/- S.E.M. are depicted. (G) Means +/-S.D. are shown. (A,B,D,E,F). One-way ANOVA. ${ }^{*} \mathrm{p}<0.05, * * \mathrm{P}<0.01, * * * \mathrm{p}<0.001$ and $* * * * \mathrm{p}<0.0001$. 
A
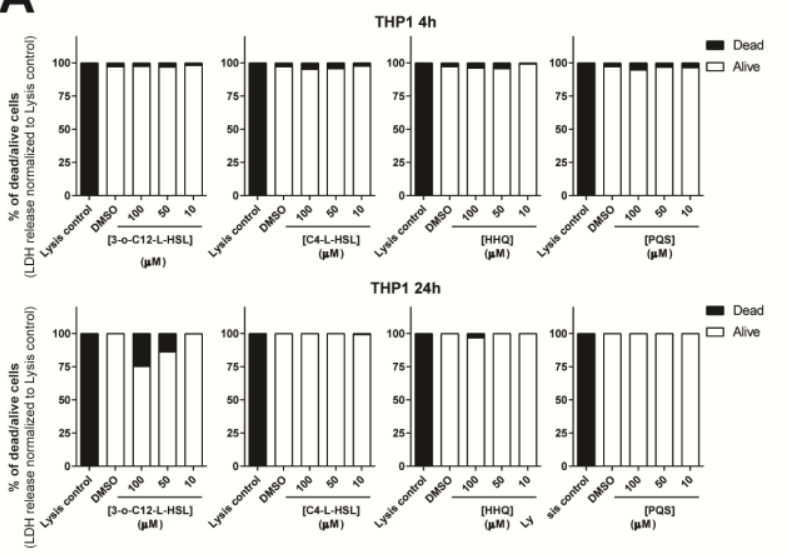
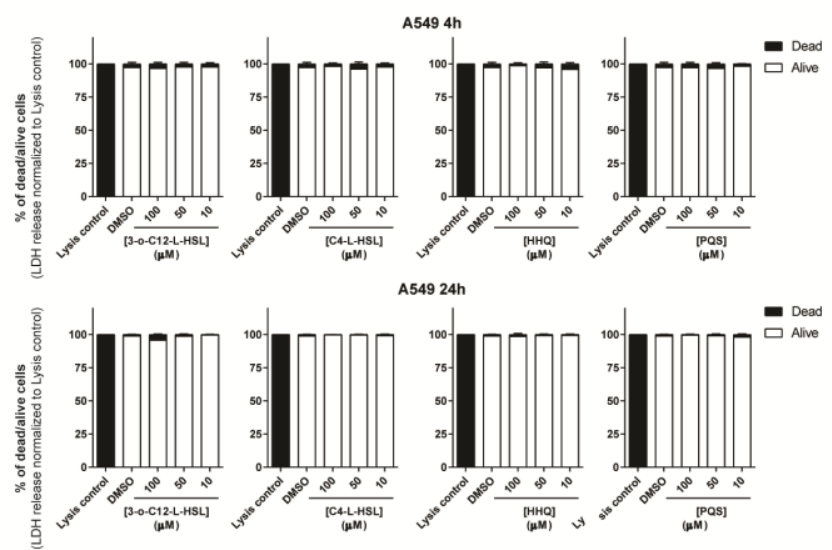

A549 24h

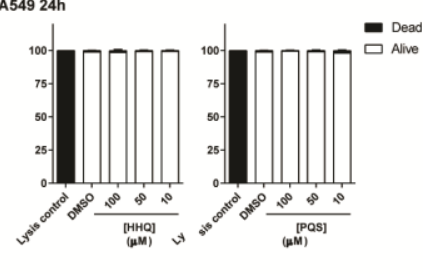

B
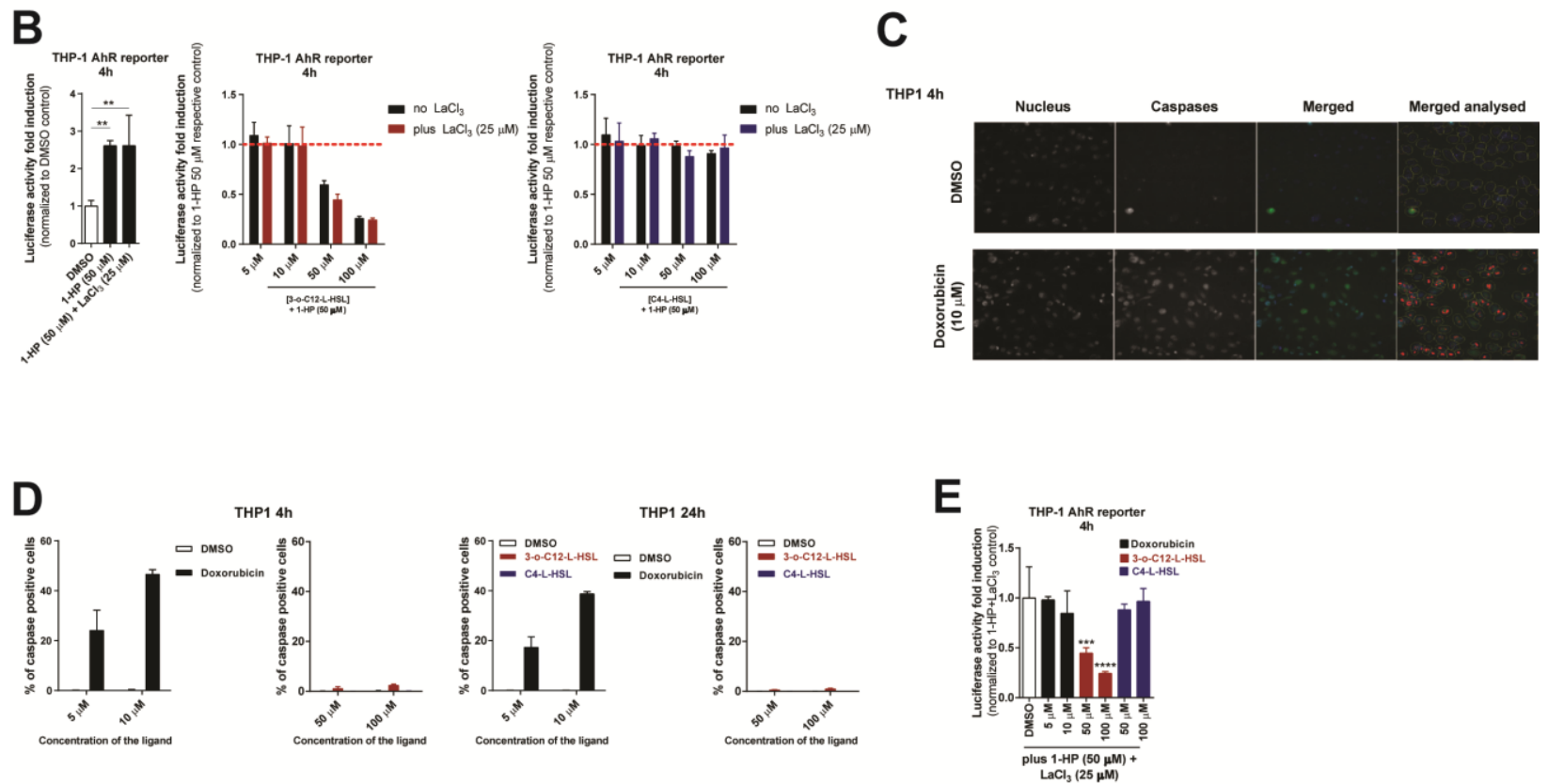

Fig. S2. Cell viability upon exposure to P.aeruginosa QS molecules. (A) Determination of the percentage of viable cells (THP-1 or A549) by lactate dehydrogenase release (LDH) after $4 \mathrm{~h}$ or 24h incubation with various concentrations of QS molecules. Pooled data from: THP-1 $(\mathrm{n}=2)$ or A549 $(\mathrm{n}=4)$ independent experiments. (B-E) Shiner et al (80) reported that apoptosis induced by $3-\mathrm{o}-\mathrm{C} 12-\mathrm{L}-\mathrm{HSL}$ can be blocked by Lanthanum chloride $(\mathrm{LaCl} 3)$, leaving its immunomodulatory properties unaffected. (B) Luciferase activity of THP-1 AhR reporter cells upon incubation with 1-HP $(50 \mu \mathrm{M})$ and various concentrations of 3-o-C12-L-HSL or C4-L-HSL, in presence or absence of Lanthanum chloride $\left(\mathrm{LaCl}_{3}, 25 \mu \mathrm{M}\right)$. (C,D) Cell viability measured by Caspase 3/7 staining of THP-1 cells after stimulation for 4 or $24 \mathrm{~h}$ with increasing concentrations of 3-o-C12-L-HSL or C4-L-HSL, or with Doxorubicin $(10 \mu \mathrm{M})$. (D,E) Incubation of THP-1 AhR reporter for $4 \mathrm{~h}$ with increasing concentrations of 3-o-C12-L-HSL, C4-L-HSL or Doxorubicin, in the presence of 1-HP $(50 \mu \mathrm{M})$ and $\mathrm{LaCl}_{3}(25 \mu \mathrm{M})$. Evaluation of (D) caspase 3/7 positive cells; (E) Luciferase AhR activity. (B-E)The presence or absence of $\mathrm{LaCl}_{3}$ did neither affect $\mathrm{AhR}$ 
activation induced by 1-HP, nor inhibition mediated by 3-o-C12-L-HSL (B). Moreover, the presence of the apoptosis inducer Doxorubicin did not fully recapitulate the inhibition mediated by 3-o-C12-L-HSL (C-E). (A) Data are pooled from at least 2 independent experiments. (B-E) Data from 1 representative experiment out of at least 3 independent experiments. (A) Means $+/-$ S.E.M. are depicted. (B-E) Means +/- S.D. are depicted. (B left panel, E) One-way ANOVA. (B middle or right panels) Two-way ANOVA (blocking for each concentration). $* * \mathrm{P}<0.01$, *** $\mathrm{p}<0.001$ and $* * * * \mathrm{p}<0.0001$. 


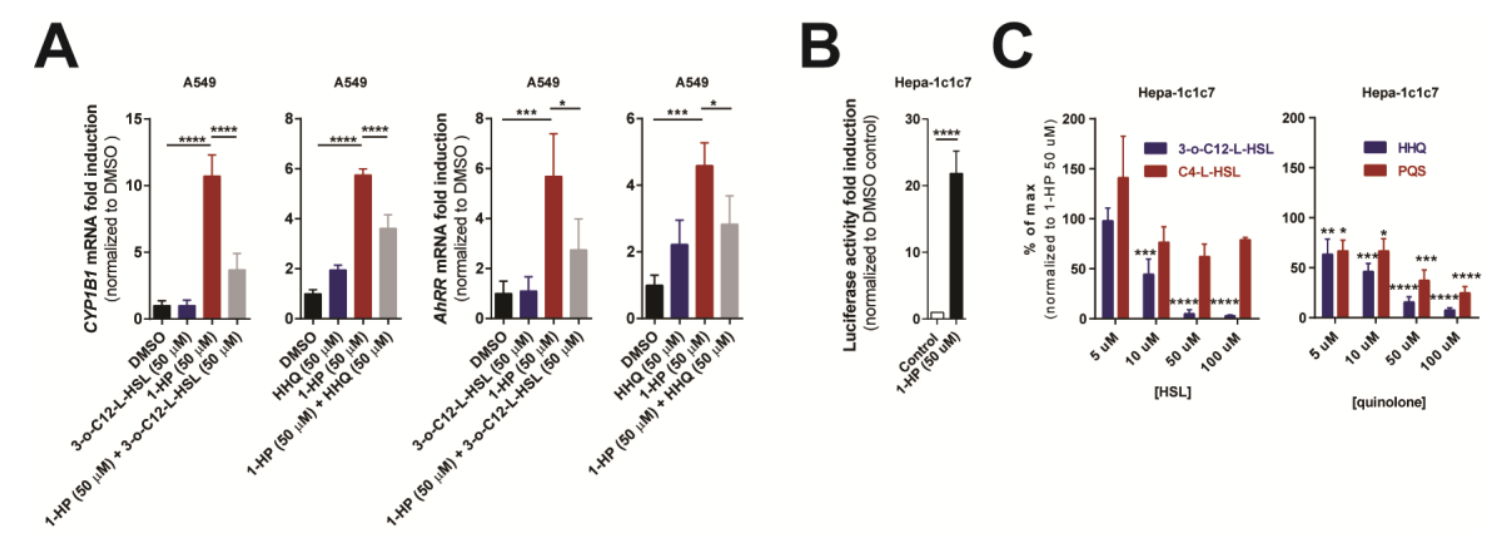

Fig. S3. AhR modulation by P.aeruginosa QS molecules. (A) AhRR and CYPIB1 gene expression in A549 cells stimulated with QS molecules for 24h. Data from 1 representative experiment out of at least 3 independent experiments. (B,C) Luciferase activity of hepatocytic (Hepa-1c1c7) luciferase AhR reporter upon 4h stimulation with 1-HP $(50 \mu \mathrm{M})$ in the presence or absence of different concentrations of QS molecules. Data are pooled from: B ( $n=8)$ or $C(n=4)$ independent experiments. (A) Means +/-S.D. are depicted. (B,C) Means +/- S.E.M. are depicted. (A-C) One-way ANOVA. ${ }^{*} \mathrm{p}<0.05, * * \mathrm{P}<0.01, * * * \mathrm{p}<0.001$ and $* * * * \mathrm{p}<0.0001$ 
A

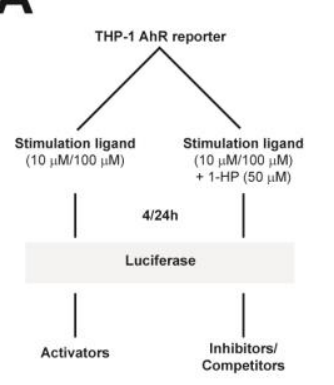

B

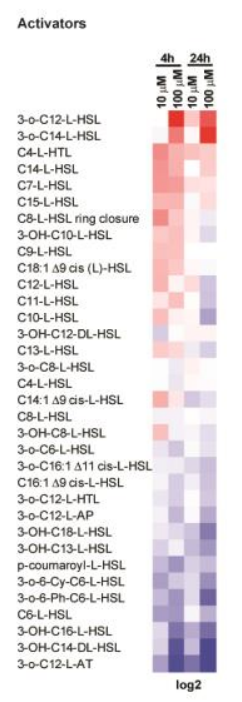

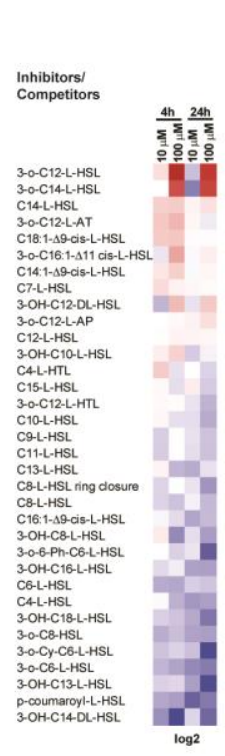

C
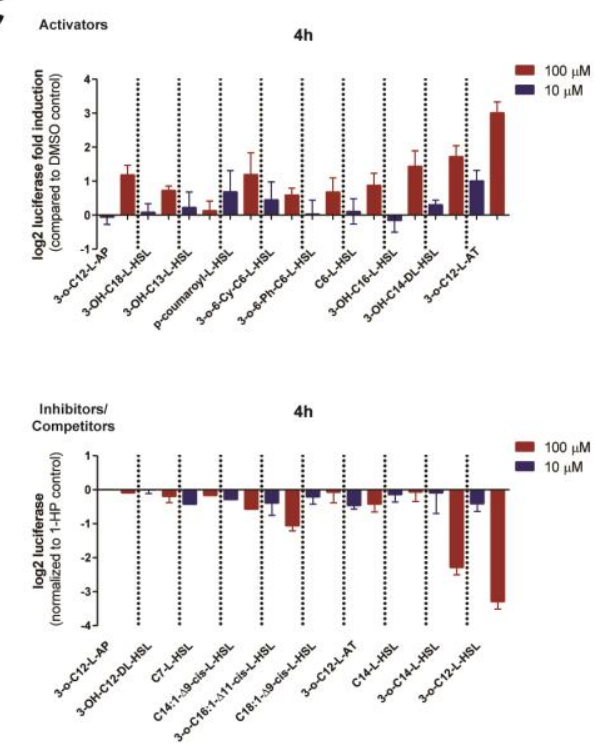

D

E

$\mathbf{F}$

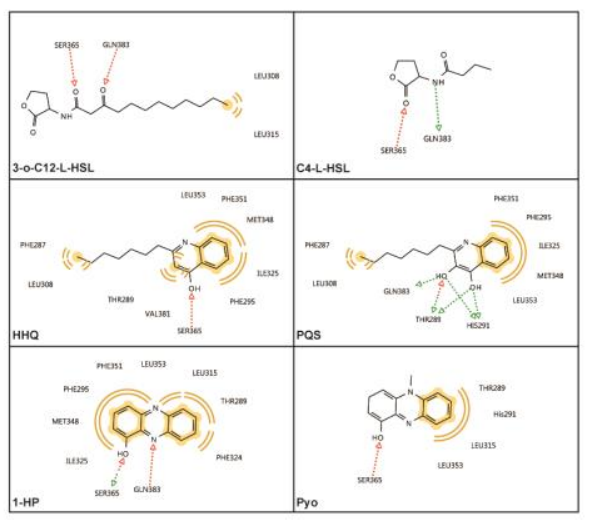

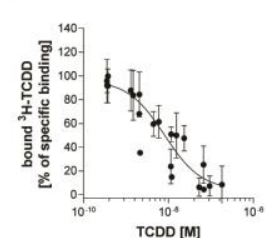

G

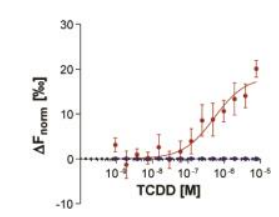

Fig. S4. AhR modulation by QS related molecules and AhR binding studies. (A) AhR modulation by QS related molecules and AhR binding studies. (A) Scheme of a Luciferase AhR reporter screen to evaluate QS related molecules capable of modulating AhR activity. (B,C) Identification of molecules capable of activating or inhibiting/competing AhR activity, in THP-1 AhR reporter cells, in presence or absence of 1-HP $(50 \mu \mathrm{M})$. Data pooled from $n=3-6$ independent experiments. (D) Results for best scoring complexes for the hAhR homology model. Table indicates potential hydrogen bonds, aromatic interactions, as well as estimated binding affinity by GlideScore and $\Delta \mathrm{G}^{\text {bind }}$, calculated in Maestro 11v0 software. (E) Best docking pose for each of the investigated ligands as 2D-interaction plot (green dashed: hydrogen donor, red dashed: hydrogen acceptor, orange: hydrophobic interactions (plots drawn by LigandScout 4.1). (F,G) Binding of 2,3,7,8-Tetrachlorodibenzodioxin(TCDD) to AhR, measured by (F) displacement of radioactive $\left[{ }^{3} \mathrm{H}\right]$ labelled $\operatorname{TCDD}\left(\left[{ }^{3} \mathrm{H}\right] \mathrm{TCDD}\right)$ from AhR in WT mouse liver cytosol $(\mathrm{n}=11$ independent experiments) or (G) by Microscale Thermophoresis assay ( $\mathrm{n}=4$ independent experiments). (C,F,G) Means +/- S.E.M. are depicted. 
A

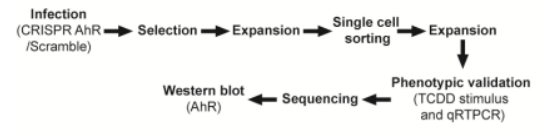

D

G

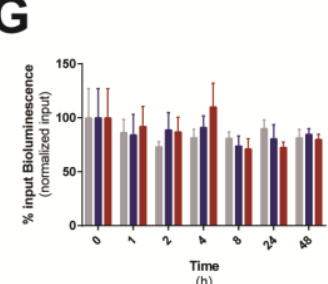

E

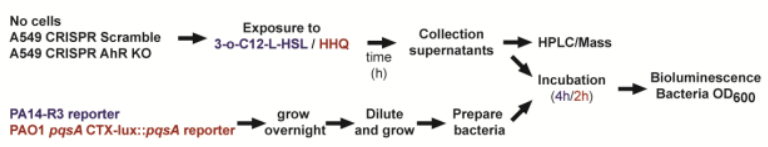

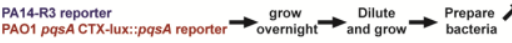

$\mathbf{H}$
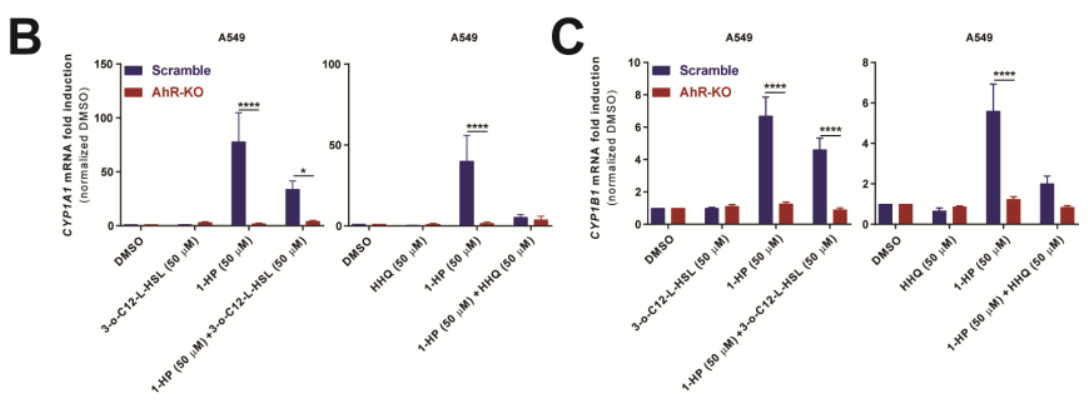

$\mathbf{F}$
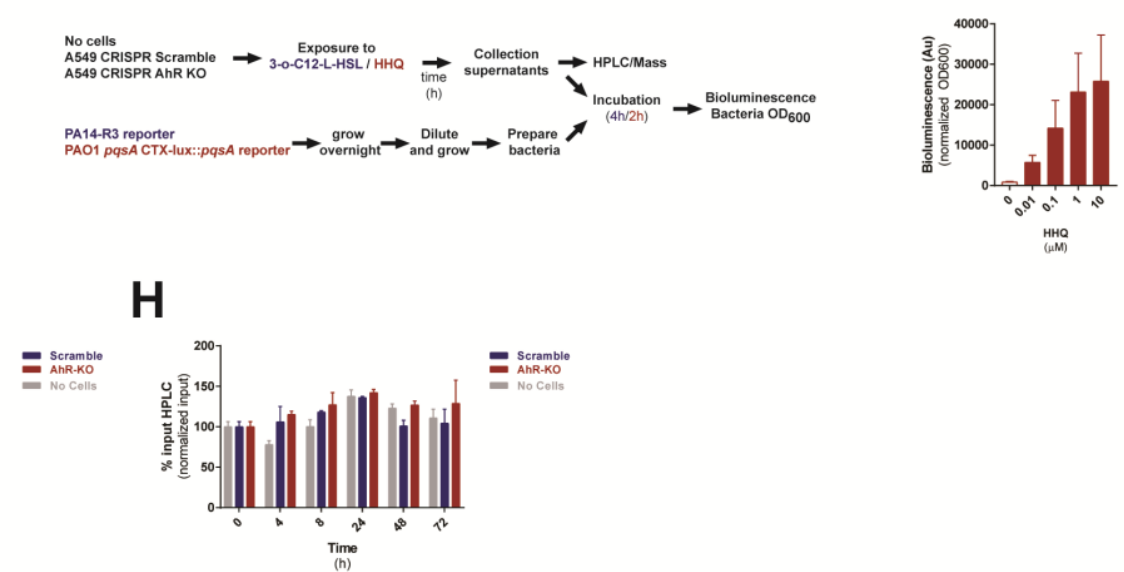

Fig. S5. AhR dependent responses to QS molecules. (A) Scheme of A549 CRISPR Scramble and A549 CRISPR AhR-KO cell line generation. (B-C) CYP1A1 (B) and CYP1B1 (C) gene expression in A549 CRISPR (Scramble and AhR-KO) cells upon 24h stimulation with P.aeruginosa QS molecules. Data pooled from: panels B, C left $(\mathrm{n}=7)$ or $\mathrm{B}, \mathrm{C}$ right $(\mathrm{n}=5)$ independent experiments (D) Bioluminescence determination of PA14-R3 after incubation with increasing concentrations of 3-o-C12-L-HSL for $4 \mathrm{~h}$. Data from 1 representative experiment of at least 3 independent experiments. (E) Scheme of degradation studies performed using a bacterial PA14-R3 reporter strain to detect 3-o-C12-L-HSL and a PAO1 pqsA CTX-lux::pqsA bacterial reporter strain to detect HHQ, after exposure of A549 (CRISPR Scramble and CRISPR AhR-KO) to the respective QS molecules. (F) PAO1 pqsA CTX-lux::pqsA bioluminescence determination after incubation with increasing concentrations of HHQ for $2 \mathrm{~h}$. Data from 1 representative experiment of at least 3 independent experiments. (G,H) Degradation of HHQ $(50 \mu \mathrm{M})$, measured in the supernatants of stimulated A549 CRISPR cells, compared to control without cells. HHQ expression levels detected by (G) bacterial PAO1 pqsA CTX-lux::pqsA bioluminescence reporter assay ( $\mathrm{n}=1$ experiment) or $(\mathbf{H})$ HPLC ( $\mathrm{n}=2$ independent experiments). (B,C, H) Data depicted as Means +/- S.E.M. (D,F,G) Data depicted as Means +/- S.D. (B,C,G,H) Two-way ANOVA. * $\mathrm{p}<0.05$ and $* * * * \mathrm{p}<0.0001$. 
A

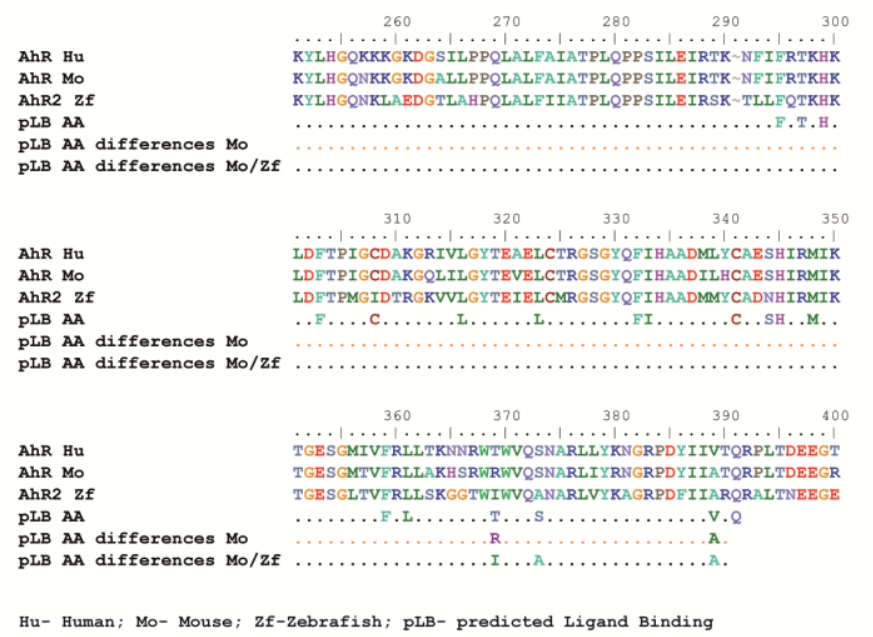

B

\begin{tabular}{|c|c|c|c|}
\hline & $\begin{array}{c}\text { AhR- } \\
\text { human }\end{array}$ & $\begin{array}{l}\text { AhR- } \\
\text { mouse }\end{array}$ & $\begin{array}{c}\text { AhR2- } \\
\text { zebrafish }\end{array}$ \\
\hline $\begin{array}{c}\text { TCDD } \\
\text { (MM-GBSA } \triangle \mathrm{G} \text { Bind }[\mathrm{kcal} / \mathrm{mol}])\end{array}$ & -42.43 & -64.86 & -66.19 \\
\hline $\begin{array}{c}\mathrm{CH}-223191 \\
\text { (MM-GBSA } \Delta \mathrm{G} \text { Bind }[\mathrm{kcal} / \mathrm{mol}])\end{array}$ & -73.11 & -70.24 & -78.13 \\
\hline
\end{tabular}

C

\begin{tabular}{|c|c|c|c|}
\hline & $\begin{array}{c}\text { AhR- } \\
\text { human }\end{array}$ & $\begin{array}{l}\text { AhR- } \\
\text { mouse }\end{array}$ & $\begin{array}{l}\text { AhR2- } \\
\text { zebrafish }\end{array}$ \\
\hline $\begin{array}{c}\text { 3-o-C12-L-HSL } \\
\text { (MM-GBSA } \Delta \text { G Bind }[\mathrm{kcal} / \mathrm{mol}])\end{array}$ & -54.05 & -51.61 & -51.55 \\
\hline $\begin{array}{c}\text { C4-L-HSL } \\
\text { (MM-GBSA } \Delta \text { G Bind }[\mathrm{kcal} / \mathrm{mol}])\end{array}$ & -35.75 & -39.12 & -31.36 \\
\hline $\begin{array}{c}\mathrm{HHQ} \\
\text { (MM-GBSA } \triangle \mathrm{G} \text { Bind }[\mathrm{kcal} / \mathrm{mol}])\end{array}$ & -52.82 & -56.26 & -45.99 \\
\hline $\begin{array}{c}\text { PQS } \\
\text { (MM-GBSA } \triangle \mathrm{G} \text { Bind }[\mathrm{kcal} / \mathrm{mol}])\end{array}$ & -44.07 & -42.82 & -46.04 \\
\hline $\begin{array}{c}\text { 1-HP } \\
\text { (MM-GBSA } \Delta \mathrm{G} \text { Bind }[\mathrm{kcal} / \mathrm{mol}])\end{array}$ & -50.75 & -46.73 & -54.50 \\
\hline $\begin{array}{c}\text { Pyo } \\
\text { (MM-GBSA } \Delta \text { G Bind }[\mathrm{kcal} / \mathrm{mol}])\end{array}$ & -50.23 & -53.35 & -49.31 \\
\hline
\end{tabular}

Fig. S6. AhR homologues and ligand binding. (A) Alignment of the human (Hu), mouse (Mo) and zebrafish $(\mathrm{Zf}) \mathrm{AhR}$ molecules indicating the aminoacids predicted to participate in ligand binding (pLB AA). Differences in conservation between the pLB AA among the different species are highlighted in the last rows. (B, C) Results for best scoring complexes for the hAhR homology model. Table indicates the estimated binding affinity by DG bind, calculated in Maestro 11v0 software. $\Delta \mathrm{G}^{\text {Bind }}$ values were calculated starting from the same ligand pose as obtained for the human AhR. (B) TCDD as an example of an AhR agonist and CH223191 as an example of an AhR inhibitor. (C) P.aeruginosa QS molecules. 
A

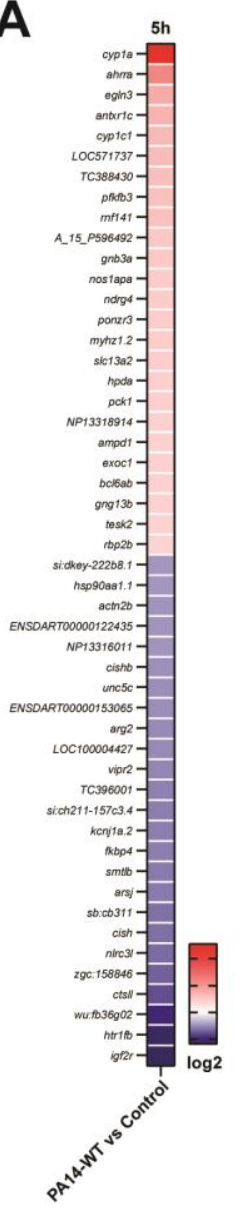

B

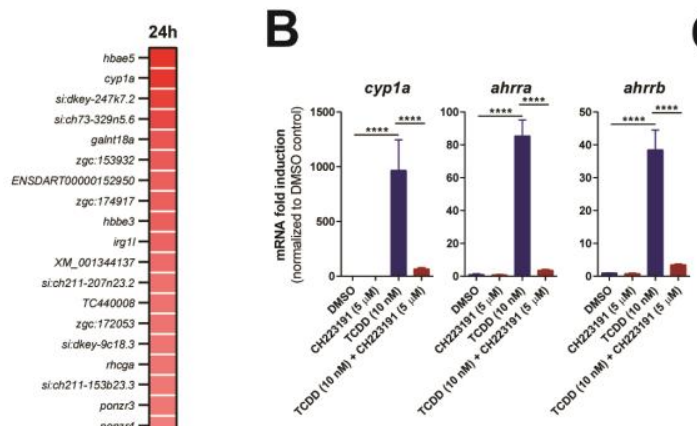

E

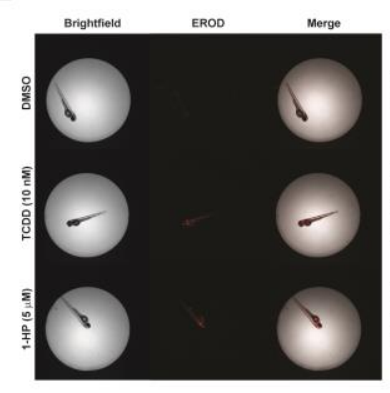

C
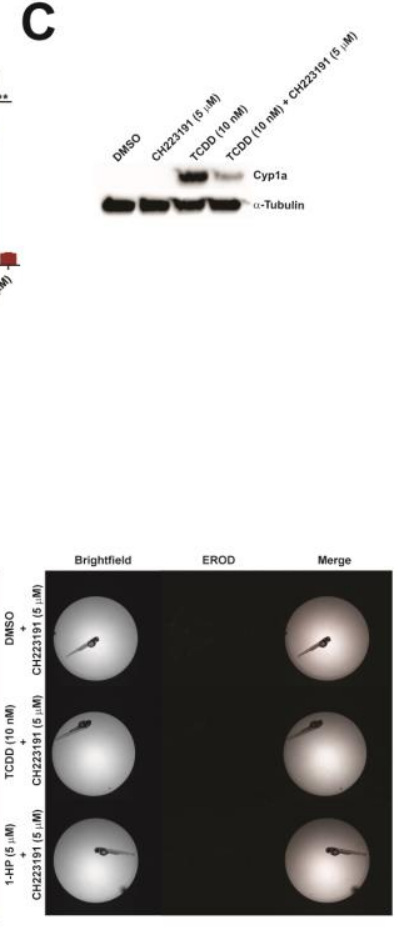

D

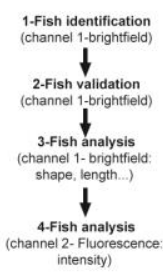

$\mathbf{F}$

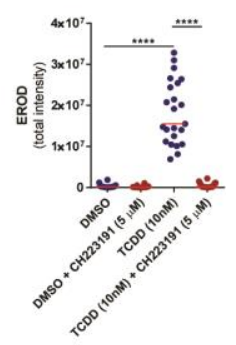

G

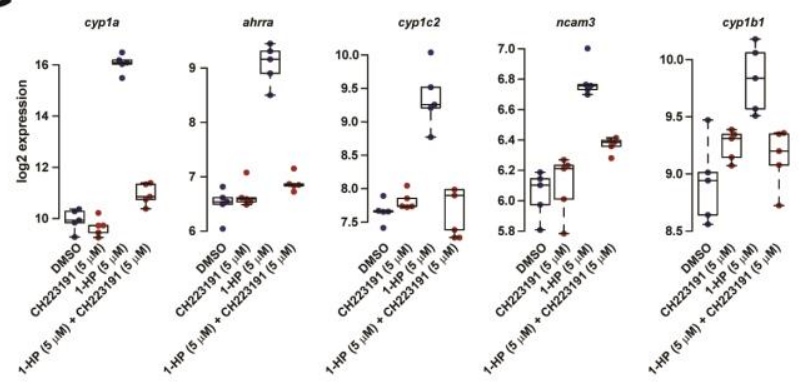

H
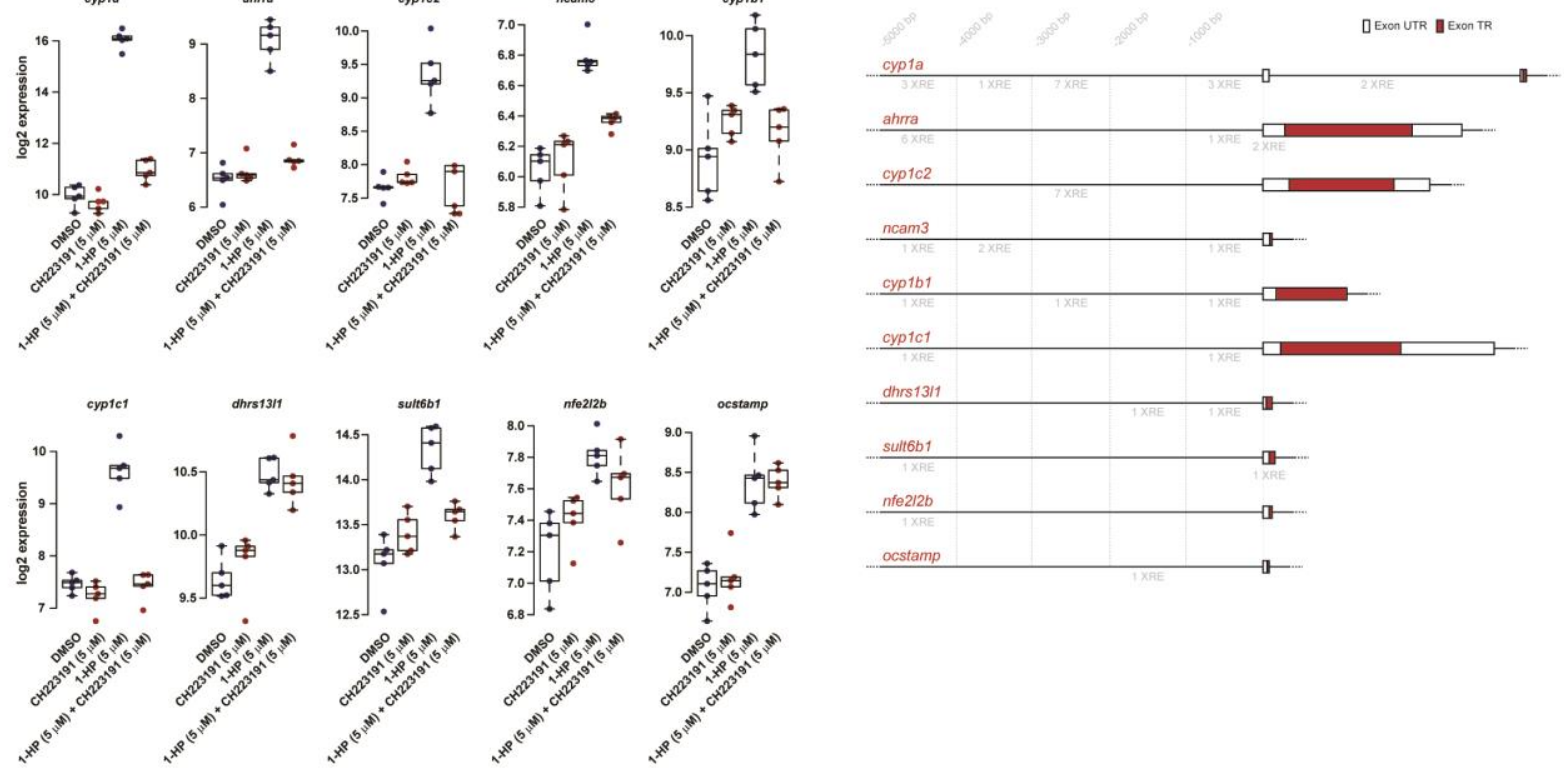

Fig. S7. AhR dependent responses in zebrafish larvae. (A) Microarray gene expression analysis of $2 \mathrm{dpf}$ zebrafish larvae upon $5 \mathrm{~h}$ or $24 \mathrm{~h}$ infection by immersion with $1 \times 10^{9} \mathrm{CFU} / \mathrm{mL}$ of 
P.aeruginosa PA14-WT, collected at mid log growth phase. (B,C) Gene expression analysis of cypla, ahrra and ahrrb transcripts from zebrafish larvae (2 days post-fertilization, dpf) treated (red) or untreated (blue) for $2 \mathrm{~h}$ with $5 \mu \mathrm{M}$ of the AhR inhibitor $\mathrm{CH} 223191$, followed by further $4 \mathrm{~h}$ exposure with TCDD $(10 \mathrm{nM})$ or DMSO vehicle control. Triplicates of 12 larvae depicted in each data point. One representative experiment out of at least 3 independent experiments. (C) Cyp1a protein expression detected by WB in 2dpf zebrafish larvae treated for $24 \mathrm{~h}$ with DMSO, TCDD $(10 \mathrm{nM})$, in the presence or absence of CH223191 $(5 \mu \mathrm{M})$. (D-F) Cyp1a enzymatic assay (EROD) in 2dpf zebrafish larvae. (D) Scheme of the assay used to measure Cyp1a enzymatic activity. (E,F) (E) Representative images of Cyp1 a enzymatic activity expressed as (F) total intensity of resorufin (EROD assay) detected per 2dpf larvae treated (red) or untreated (blue) for 2h with $\mathrm{CH} 223191$ (5 $\mu \mathrm{M})$ followed by further $4 \mathrm{~h}$ exposure with TCDD $(10 \mathrm{nM})$ or DMSO vehicle control. Each data point represents a single larva. One representative experiment out of at least 3 independent experiments. (G) Microarray analysis of 2dpf larvae pre-exposed to DMSO or CH223191 (5 $\mu \mathrm{M})$ for $2 \mathrm{~h}$, followed by $4 \mathrm{~h}$ exposure to P.aeruginosa 1 -HP $(5 \mu \mathrm{M})$ or DMSO, in presence or absence of $\mathrm{CH} 223191(5 \mu \mathrm{M})$. Data are pooled from 5 independent experiments, triplicates of 12 larvae depicted in each data point (H) In silico prediction of Xenobiotic Response Elements (XRE) in the promoter region of different genes. UTR-untranslated region; TR-translated region. (B) Means +/S.D. are depicted. (F) Median is depicted. (B, F) One-way ANOVA. ****p $<0.0001$. 
A
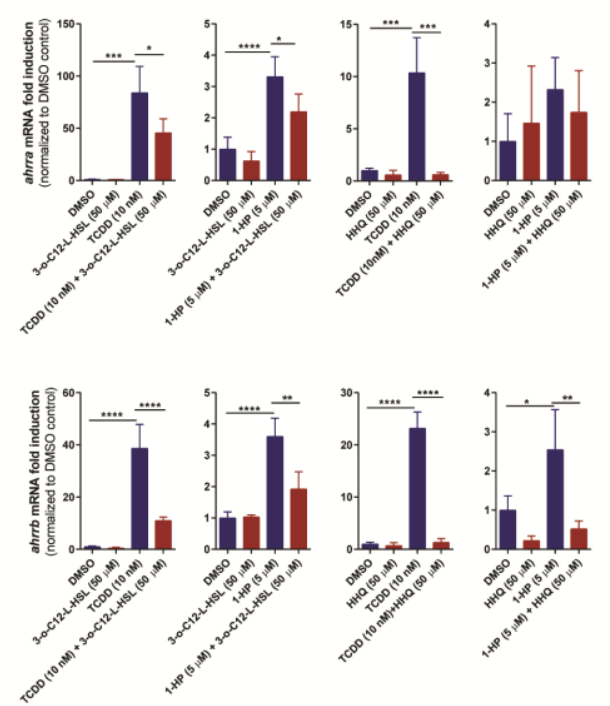

C
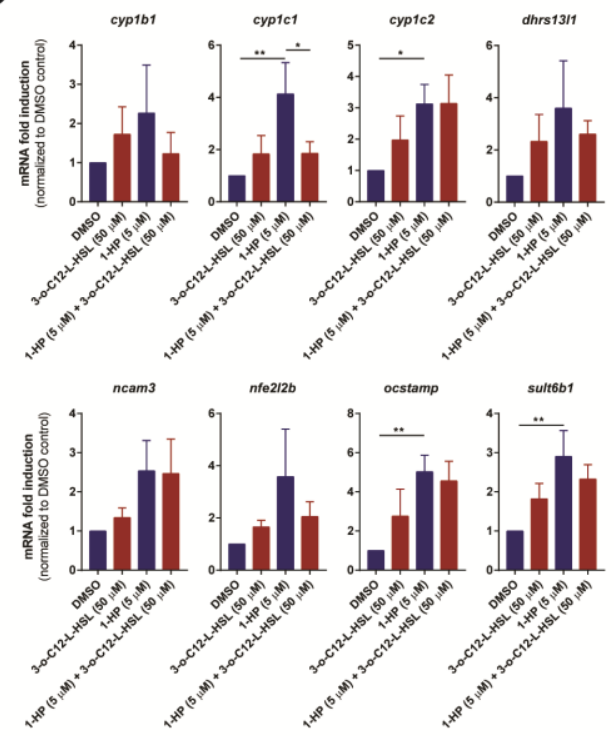

E

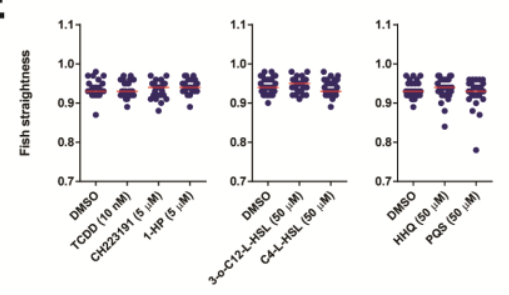

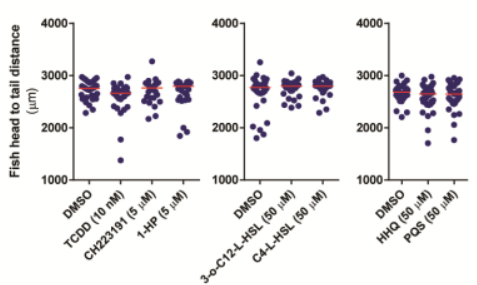

B

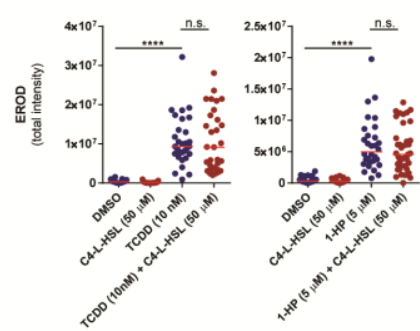

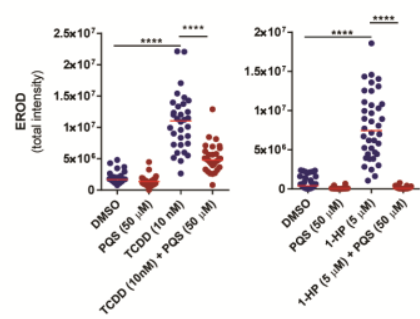

D
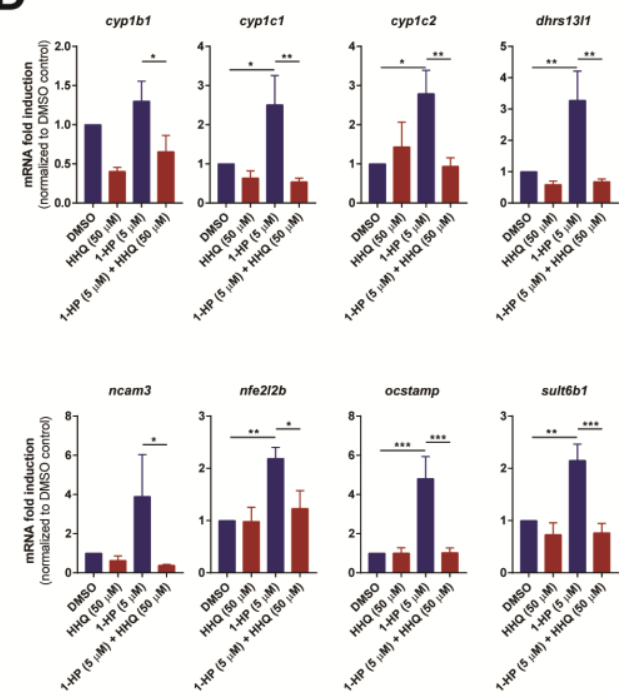
Fig. S8. AhR modulation in zebrafish larvae upon exposure to P.aeruginosa QS molecules. (A,C,D) Gene expression analysis or (B) Cypla enzymatic activity upon 4h exposure of $2 \mathrm{dpf}$ larvae to various P.aeruginosa QS molecules or TCDD. (E) Toxicity assessment of $2 \mathrm{dpf}$ zebrafish larvae upon exposure to different ligands, measured by straightness or total head to tail distance. $(\mathbf{A}, \mathbf{B}, \mathbf{E})$ Data from 1 representative experiment out of at least 3 independent experiments. (A) Triplicates of 12 larvae depicted in each data point or $(\mathbf{B}, \mathbf{E})$ each data point represents a single larva. (C,D) Pooled data from $n=5$ independent experiments. (A) Means +/- S.D. are depicted. (C,D) Means +/- S.E.M. are depicted. (B,E) Medians are depicted. (A-E) One-way ANOVA. $* \mathrm{p}<0.05, * * \mathrm{p}<0.01, * * * \mathrm{p}<0.001$ and $* * * * \mathrm{p}<0.0001$. 


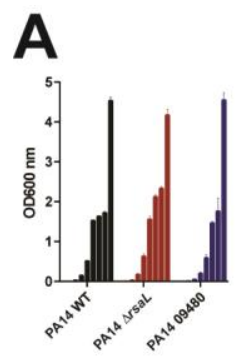

B
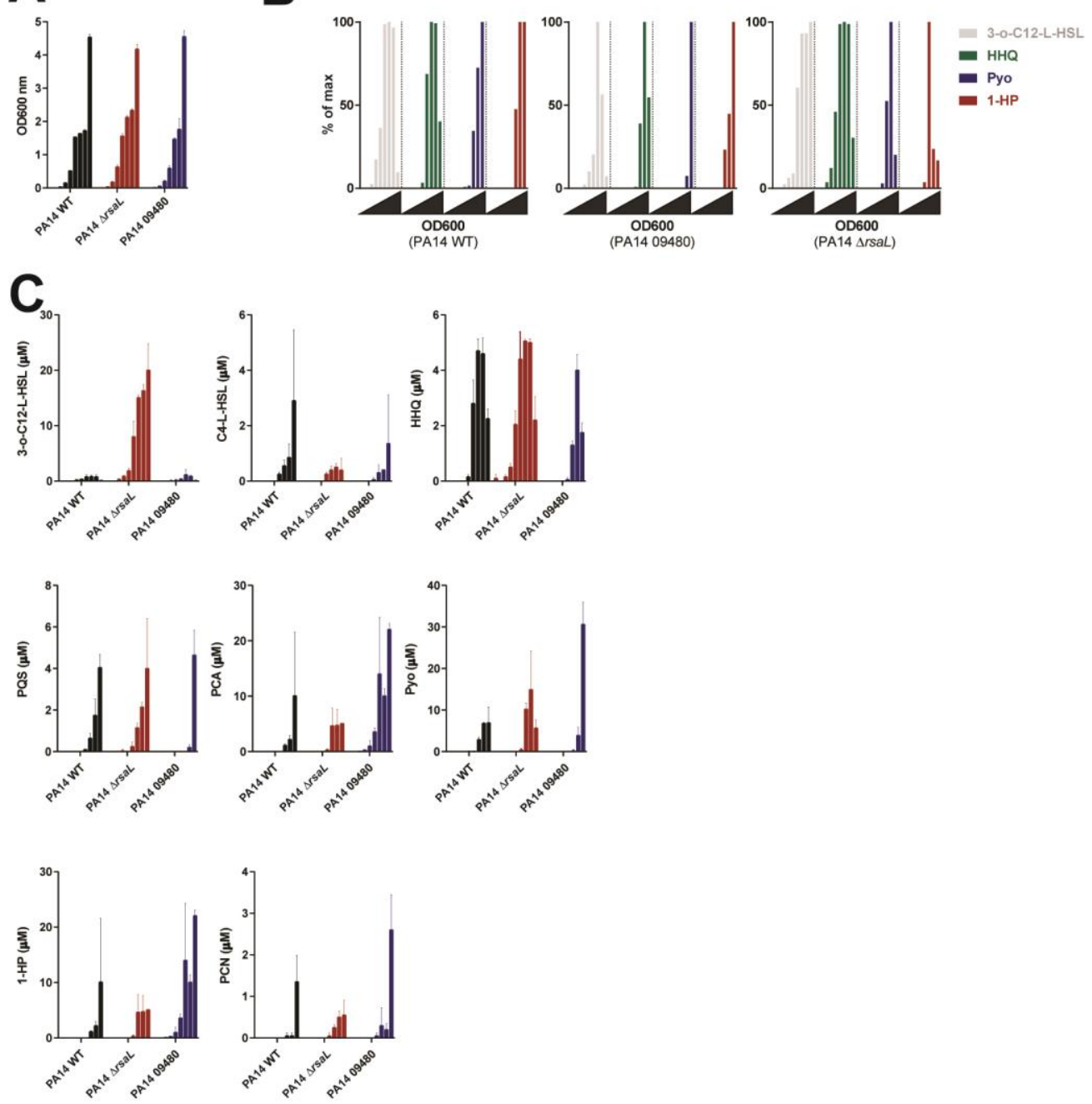

Fig. S9. P.aeruginosa QS expression dynamics (A) Growth curves of P.aeruginosa strains PA14-WT, PA14- $\Delta r s a L$ and PA14-09480 ( $\mathrm{n}=2$ independent experiments). (B,C) Kinetics of expression of different QS molecules in diverse P.aeruginosa strains, measured by HPLC ( $\mathrm{n}=2$ independent experiments). 


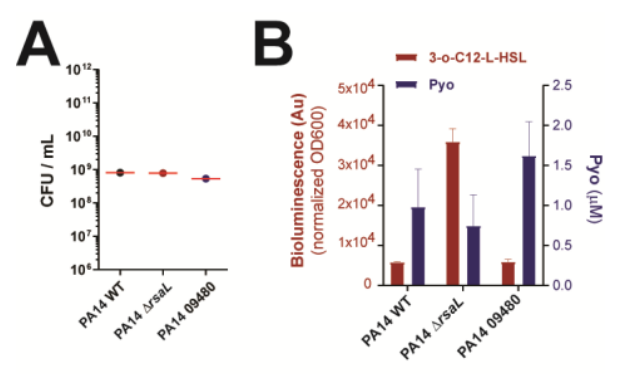

Fig. S10. P.aeruginosa infection of zebrafish larvae. (A) PA14 WT, PA14 $\Delta r s a L$ and PA14 09480 inoculum CFU administered to zebrafish by immersion. Data from 1 representative experiment of at least 3 independent experiments. (B) Expression of 3-o-C12-L-HSL and Pyo in the water of zebrafish larvae after $5 \mathrm{~h}$ infection with different PA14 strains ( $\mathrm{n}=7$ independent experiments). (A) Means are depicted. (B) Means +/- S.E.M. are depicted. 

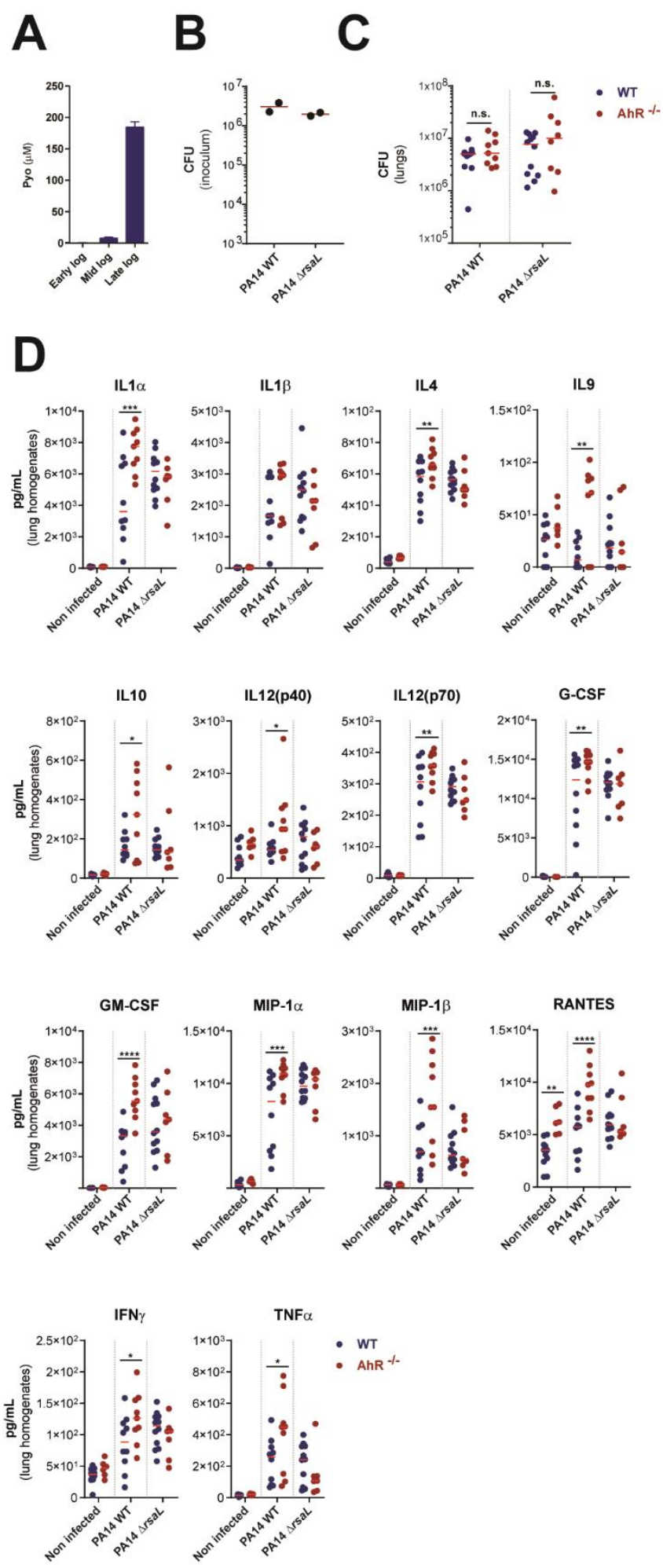

Fig. S11. P.aeruginosa infection of mice. (A) Pyocyanin (Pyo) concentrations in bacteria free supernatants of PA14-09480 strain grown in LB. (B-D) AhR deficient $\left(A h R^{-/}\right)$and proficient (WT) mice were infected intratracheally for 8h with PA14 WT and PA14 $\Delta r s a L$ strains. (B) PA14 WT and PA14 $\Delta$ rsaL inoculum CFU administered to mice. Each dot represents the CFU from 
each experiment. (C) Bacterial counts in the lungs of infected mice. Each dot represents 1 mouse (D) Cytokine and chemokine protein levels in lung homogenates after infection. Each dot represents 1 mouse. (A-D) Data are pooled from 2 independent experiments. (A)Means +/- S.E.M are depicted. (B-D) Medians are shown. (C) Mann-Whitney U-test. (D) Two-way ANOVA. n.s.not significant, $* \mathrm{p}<0.05, * * \mathrm{p}<0.01, * * * \mathrm{p}<0.001$ and $\mathrm{p}<0.0001$. 


\section{Table S1.}

List of QS molecules and analogues tested.

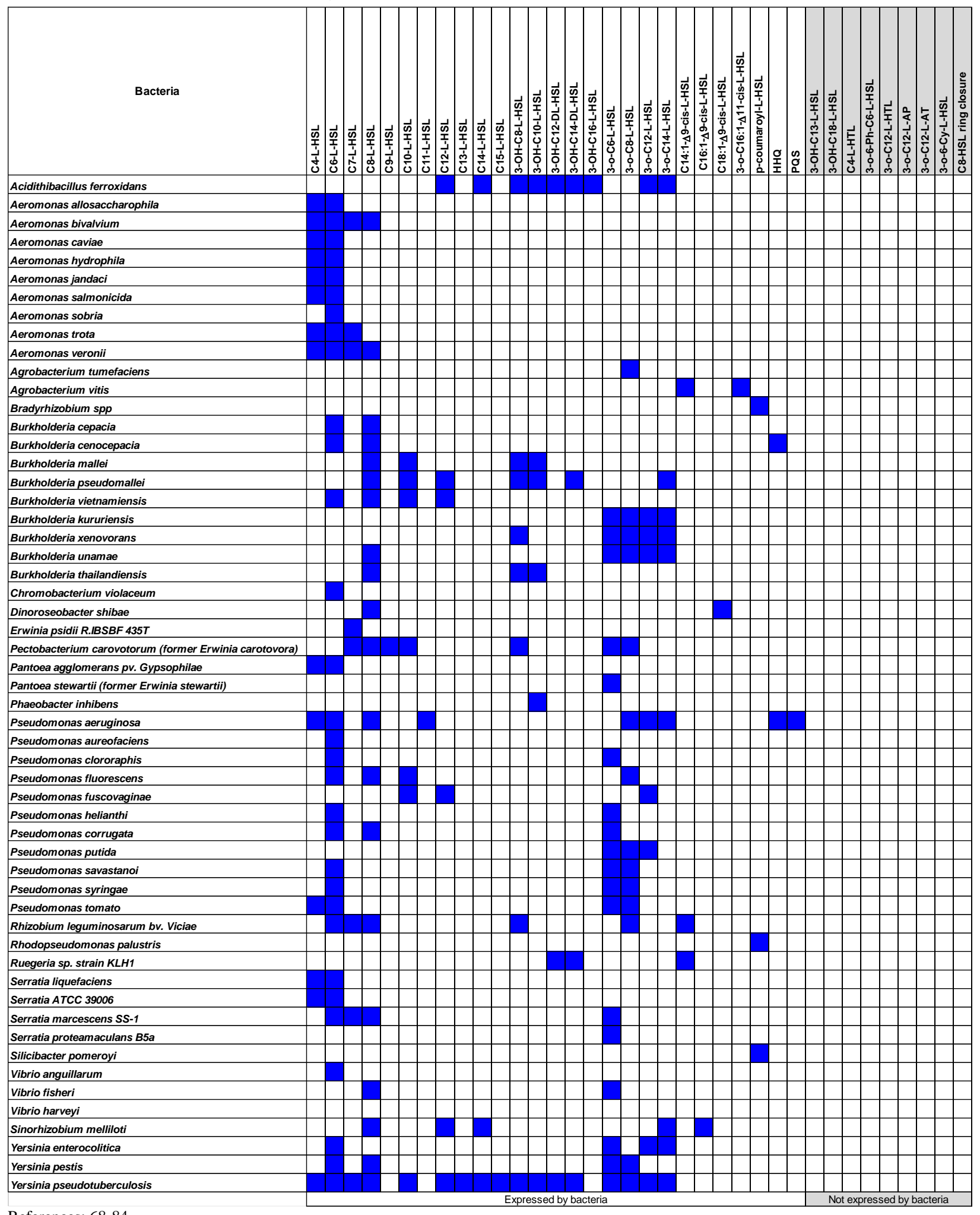




\section{Table S2.}

List of genes differentially expressed upon $5 \mathrm{~h}$ infection of zebrafish larvae ( 2 days post fertilization) with PA14-WT.

\begin{tabular}{|c|c|c|c|}
\hline Sequence Name(s) & Sequence Description & $\begin{array}{l}\log _{2} \mathbf{F C} \\
\text { (PA14- } \\
\text { WT vs } \\
\text { Control) }\end{array}$ & p-Value \\
\hline cyp1a & $\begin{array}{l}\text { ref|Danio rerio cytochrome P450, family } \\
\text { 1, subfamily A (cyp1a), mRNA } \\
\text { [NM_131879] }\end{array}$ & 5.07 & $3.24 \mathrm{E}-25$ \\
\hline cyp1a & $\begin{array}{l}\text { ref|Danio rerio cytochrome P450, family } \\
\text { 1, subfamily A (cyp1a), mRNA } \\
\text { [NM_131879] }\end{array}$ & 3.34 & $1.48 \mathrm{E}-19$ \\
\hline cyp1a & $\begin{array}{l}\text { ref|Danio rerio cytochrome P450, family } \\
\text { 1, subfamily A (cyp1a), mRNA } \\
\text { [NM_131879] }\end{array}$ & 2.43 & $2.69 \mathrm{E}-16$ \\
\hline ahrra & $\begin{array}{l}\text { ref|Danio rerio aryl-hydrocarbon receptor } \\
\text { repressor a (ahrra), mRNA } \\
\text { [NM_001035265] }\end{array}$ & 2.30 & $1.62 \mathrm{E}-17$ \\
\hline$e g \ln 3$ & $\begin{array}{l}\text { ref|Danio rerio egl-9 family hypoxia- } \\
\text { inducible factor } 3(\text { egln3), mRNA } \\
\text { [NM_213310] }\end{array}$ & 1.55 & 4.57E-06 \\
\hline antxr1c & $\begin{array}{l}\text { ens|ANTXR cell adhesion molecule 1c } \\
\text { [Source:ZFIN;Acc:ZDB-GENE-090514- } \\
\text { 5] [ENSDART00000093113] }\end{array}$ & 1.38 & 4.04E-03 \\
\hline cyp1c1 & $\begin{array}{l}\text { ref|Danio rerio cytochrome P450, family } \\
\text { 1, subfamily C, polypeptide } 1 \text { (cyp1c1), } \\
\text { mRNA [NM_001020610] }\end{array}$ & 1.28 & 6.47E-08 \\
\hline LOC571737 & $\begin{array}{l}\text { ens|high affinity cGMP-specific 3',5'- } \\
\text { cyclic phosphodiesterase 9A-like } \\
\text { [Source:NCBI gene;Acc:571737] } \\
\text { [ENSDART00000181584] }\end{array}$ & 1.23 & $2.10 \mathrm{E}-03$ \\
\hline cyp1c1 & $\begin{array}{l}\text { ref|Danio rerio cytochrome P450, family } \\
\text { 1, subfamily C, polypeptide } 1 \text { (cyplc1), } \\
\text { mRNA [NM_001020610] }\end{array}$ & 1.18 & $1.14 \mathrm{E}-05$ \\
\hline TC388430 & $\begin{array}{l}\text { tc|Rep: Forkhead box protein G1 - Homo } \\
\text { sapiens (Human), partial (4\%) } \\
\text { [TC388430] }\end{array}$ & 1.17 & $1.04 \mathrm{E}-04$ \\
\hline$p f k f b 3$ & $\begin{array}{l}\text { ref|Danio rerio 6-phosphofructo-2- } \\
\text { kinase/fructose-2,6-biphosphatase } 3 \\
\text { (pfkfb3), mRNA [NM_213397] }\end{array}$ & 1.13 & $2.65 \mathrm{E}-06$ \\
\hline rnf141 & $\begin{array}{l}\text { ref|Danio rerio ring finger protein 141 } \\
\text { (rnf141), mRNA [NM_001007290] }\end{array}$ & 1.12 & $3.22 \mathrm{E}-03$ \\
\hline A_15_P596492 & Unknown & 1.01 & $1.90 \mathrm{E}-06$ \\
\hline
\end{tabular}


ref|Danio rerio guanine nucleotide binding protein (G protein), beta polypeptide 3a

\begin{tabular}{|c|c|c|c|}
\hline gnb3a & (gnb3a), mRNA [NM_001002437] & 0.99 & $8.50 \mathrm{E}-03$ \\
\hline$e g \ln 3$ & $\begin{array}{l}\text { ref|Danio rerio egl-9 family hypoxia- } \\
\text { inducible factor } 3(\text { egln } 3) \text {, mRNA } \\
\text { [NM_213310] }\end{array}$ & 0.98 & $5.26 \mathrm{E}-04$ \\
\hline nos1apa & $\begin{array}{l}\text { ens|nitric oxide synthase } 1 \text { (neuronal) } \\
\text { adaptor protein a } \\
\text { [Source:ZFIN;Acc:ZDB-GENE-081024- } \\
\text { 1] [ENSDART00000148997] }\end{array}$ & 0.95 & $1.59 \mathrm{E}-02$ \\
\hline ndrg4 & $\begin{array}{l}\text { ref|Danio rerio NDRG family member } 4 \\
\text { (ndrg4), mRNA [NM_001045173] }\end{array}$ & 0.91 & $1.57 \mathrm{E}-02$ \\
\hline ponzr3 & $\begin{array}{l}\text { ref|Danio rerio plac8 onzin related protein } \\
3 \text { (ponzr3), mRNA [NM_001327984] }\end{array}$ & 0.91 & $3.84 \mathrm{E}-02$ \\
\hline myhz1.2 & $\begin{array}{l}\text { ref|Danio rerio myosin, heavy polypeptide } \\
1.2 \text {, skeletal muscle (myhz1.2), mRNA } \\
\text { [NM_001161446] }\end{array}$ & 0.91 & $9.44 \mathrm{E}-04$ \\
\hline slc13a2 & $\begin{array}{l}\text { ref|Danio rerio solute carrier family } 13 \\
\text { (sodium-dependent dicarboxylate } \\
\text { transporter), member } 2 \text { (slc13a2), mRNA } \\
\text { [NM_213452] }\end{array}$ & 0.88 & $1.69 \mathrm{E}-04$ \\
\hline hpda & $\begin{array}{l}\text { ref|Danio rerio 4-hydroxyphenylpyruvate } \\
\text { dioxygenase a (hpda), mRNA } \\
\text { [NM_201167] }\end{array}$ & 0.87 & $2.01 \mathrm{E}-03$ \\
\hline pck1 & $\begin{array}{l}\text { ref|Danio rerio phosphoenolpyruvate } \\
\text { carboxykinase } 1 \text { (soluble) (pck1), mRNA } \\
\text { [NM_214751] }\end{array}$ & 0.84 & $5.14 \mathrm{E}-04$ \\
\hline NP13318914 & $\begin{array}{l}\text { tc|GB|XM_001919200.1|XP_001919235. } \\
\text { 1 hypothetical protein [NP13318914] }\end{array}$ & 0.83 & $2.61 \mathrm{E}-03$ \\
\hline ampd1 & $\begin{array}{l}\text { ref|Danio rerio adenosine monophosphate } \\
\text { deaminase } 1 \text { (isoform M) (ampd1), } \\
\text { mRNA [NM_200893] }\end{array}$ & 0.83 & $4.55 \mathrm{E}-03$ \\
\hline exoc1 & $\begin{array}{l}\text { ref|Danio rerio exocyst complex } \\
\text { component } 1 \text { (exoc1), mRNA } \\
\text { [NM_199597] }\end{array}$ & 0.83 & $1.65 \mathrm{E}-02$ \\
\hline bcl6ab & $\begin{array}{l}\text { ref|Danio rerio B cell CLL/lymphoma 6ab } \\
\text { (bcl6ab), mRNA [NM_001100074] }\end{array}$ & 0.82 & $9.10 \mathrm{E}-06$ \\
\hline gng13b & $\begin{array}{l}\text { ref|Danio rerio guanine nucleotide binding } \\
\text { protein (G protein), gamma 13b (gng13b), } \\
\text { mRNA [NM_001002400] }\end{array}$ & 0.82 & $2.20 \mathrm{E}-03$ \\
\hline pck1 & $\begin{array}{l}\text { ref|Danio rerio phosphoenolpyruvate } \\
\text { carboxykinase } 1 \text { (soluble) (pck1), mRNA } \\
\text { [NM_214751] }\end{array}$ & 0.80 & $2.89 \mathrm{E}-03$ \\
\hline tesk2 & $\begin{array}{l}\text { ref|Danio rerio testis associated actin } \\
\text { remodelling kinase } 2 \text { (tesk2), mRNA } \\
\text { [NM_001110476] }\end{array}$ & 0.80 & $4.19 \mathrm{E}-03$ \\
\hline
\end{tabular}


ref|Danio rerio retinol binding protein $2 b$, cellular (rbp2b), mRNA

\begin{tabular}{|c|c|c|c|}
\hline $\operatorname{rbp} 2 b$ & [NM_001002307] & 0.79 & $9.14 \mathrm{E}-03$ \\
\hline slc13a2 & $\begin{array}{l}\text { ref|Danio rerio solute carrier family } 13 \\
\text { (sodium-dependent dicarboxylate } \\
\text { transporter), member } 2 \text { (slc13a2), mRNA } \\
\text { [NM_213452] }\end{array}$ & 0.79 & $6.46 \mathrm{E}-05$ \\
\hline ponzr4 & $\begin{array}{l}\text { ref|Danio rerio plac8 onzin related protein } \\
4 \text { (ponzr4), mRNA [NM_001327980] }\end{array}$ & 0.79 & $4.82 \mathrm{E}-02$ \\
\hline ponzr4 & $\begin{array}{l}\text { ref|Danio rerio plac8 onzin related protein } \\
4 \text { (ponzr4), mRNA [NM_001327980] }\end{array}$ & 0.79 & $2.90 \mathrm{E}-02$ \\
\hline$z g c: 136908$ & $\begin{array}{l}\text { ref|Danio rerio zgc:136908 (zgc:136908), } \\
\text { mRNA [NM_001039928] }\end{array}$ & 0.79 & $2.89 \mathrm{E}-04$ \\
\hline p4halb & Unknown & 0.78 & $1.47 \mathrm{E}-04$ \\
\hline EH438071 & $\begin{array}{l}\text { gb|FDR103-P00018-DEPE-F_K13 } \\
\text { FDR103 Danio rerio cDNA clone } \\
\text { FDR103-P00018-BR_K13 5', mRNA } \\
\text { sequence [EH438071] }\end{array}$ & 0.78 & 8.42E-03 \\
\hline si:dkey-47k20.8 & $\begin{array}{l}\text { ens|si:dkey-47k20.8 } \\
\text { [Source:ZFIN;Acc:ZDB-GENE-060503- } \\
\text { 359] [ENSDART00000140043] }\end{array}$ & 0.77 & 2.99E-03 \\
\hline$e e f 1 d b$ & $\begin{array}{l}\text { ref|Danio rerio eukaryotic translation } \\
\text { elongation factor } 1 \text { delta } b \text { (guanine } \\
\text { nucleotide exchange protein) (eef1db), } \\
\text { transcript variant } 1, \text { mRNA } \\
\text { [NM_001161414] }\end{array}$ & 0.77 & $5.76 \mathrm{E}-05$ \\
\hline si:busm1-266f07.2 & $\begin{array}{l}\text { ref|Danio rerio si:busm1-266f07.2 } \\
\text { (si:busm1-266f07.2), mRNA } \\
\text { [NM_001004521] }\end{array}$ & 0.76 & $1.43 \mathrm{E}-03$ \\
\hline myhz1.1 & $\begin{array}{l}\text { ref|Danio rerio myosin, heavy polypeptide } \\
1.1 \text {, skeletal muscle (myhz1.1), transcript } \\
\text { variant } 1, \text { mRNA [NM_001115089] }\end{array}$ & 0.76 & $2.00 \mathrm{E}-03$ \\
\hline gnb3a & $\begin{array}{l}\text { ref|Danio rerio guanine nucleotide binding } \\
\text { protein (G protein), beta polypeptide 3a } \\
\text { (gnb3a), mRNA [NM_001002437] }\end{array}$ & 0.75 & $2.71 \mathrm{E}-02$ \\
\hline $\operatorname{six} 7$ & $\begin{array}{l}\text { ref|Danio rerio SIX homeobox } 7 \text { (six7), } \\
\text { mRNA [NM_131354] }\end{array}$ & 0.75 & 3.37E-03 \\
\hline$z n f 395 a$ & $\begin{array}{l}\text { ref|Danio rerio zinc finger protein 395a } \\
\text { (znf395a), mRNA [NM_001080054] }\end{array}$ & 0.75 & 2.33E-04 \\
\hline slco2a1 & $\begin{array}{l}\text { ref|Danio rerio solute carrier organic } \\
\text { anion transporter family, member 2A1 } \\
\text { (slco2a1), mRNA [NM_001089582] }\end{array}$ & 0.74 & $3.71 \mathrm{E}-06$ \\
\hline hiflan & $\begin{array}{l}\text { ref|Danio rerio hypoxia inducible factor } 1 \\
\text { subunit alpha inhibitor (hif1an), mRNA } \\
\text { [NM_201496] }\end{array}$ & 0.74 & $1.16 \mathrm{E}-05$ \\
\hline
\end{tabular}


ref|Danio rerio aquaporin 9a (aqp9a),

\begin{tabular}{|c|c|c|c|}
\hline aqp9a & mRNA [NM_001033096] & 0.74 & 7.46E-03 \\
\hline gpr39 & $\begin{array}{l}\text { ref|Danio rerio G protein-coupled receptor } \\
39 \text { (gpr39), mRNA [NM_200417] }\end{array}$ & 0.73 & $3.41 \mathrm{E}-02$ \\
\hline zgc:174917 & $\begin{array}{l}\text { ref|Danio rerio zgc:174917 (zgc:174917), } \\
\text { mRNA [NM_001105590] }\end{array}$ & 0.73 & $3.77 \mathrm{E}-02$ \\
\hline aqp9a & $\begin{array}{l}\text { ref|Danio rerio aquaporin 9a (aqp9a), } \\
\text { mRNA [NM_001033096] }\end{array}$ & 0.72 & $6.51 \mathrm{E}-03$ \\
\hline zgc:158404 & $\begin{array}{l}\text { ref|Danio rerio zgc:158404 (zgc:158404), } \\
\text { mRNA [NM_001080565] }\end{array}$ & 0.72 & $8.62 \mathrm{E}-03$ \\
\hline grifin & $\begin{array}{l}\text { ref|Danio rerio galectin-related inter-fiber } \\
\text { protein (grifin), mRNA [NM_001003430] }\end{array}$ & 0.72 & $1.56 \mathrm{E}-02$ \\
\hline ampd1 & $\begin{array}{l}\text { ref|Danio rerio adenosine monophosphate } \\
\text { deaminase } 1 \text { (isoform M) (ampd1), } \\
\text { mRNA [NM_200893] }\end{array}$ & 0.72 & $6.49 \mathrm{E}-03$ \\
\hline$t s c 22 d 3$ & $\begin{array}{l}\text { ref|Danio rerio TSC22 domain family, } \\
\text { member } 3 \text { (tsc22d3), transcript variant } 1 \text {, } \\
\text { mRNA [NM_200569] }\end{array}$ & 0.72 & $2.38 \mathrm{E}-02$ \\
\hline klhl31 & $\begin{array}{l}\text { gb|Danio rerio kelch-like } 31 \text { (Drosophila) } \\
\text { (klh131), mRNA [NM_001003727] }\end{array}$ & 0.72 & $6.73 \mathrm{E}-06$ \\
\hline podn & $\begin{array}{l}\text { ens|podocan [Source:ZFIN;Acc:ZDB- } \\
\text { GENE-100922-117] } \\
\text { [ENSDART00000181882] }\end{array}$ & 0.72 & $1.35 \mathrm{E}-03$ \\
\hline mpeg1.2 & $\begin{array}{l}\text { ref|Danio rerio macrophage expressed 1, } \\
\text { tandem duplicate } 2 \text { (mpeg1.2), mRNA } \\
{[\text { [NM_001020586] }}\end{array}$ & 0.72 & $1.25 \mathrm{E}-02$ \\
\hline TC388430 & $\begin{array}{l}\text { tc|Rep: Forkhead box protein G1 - Homo } \\
\text { sapiens (Human), partial (4\%) } \\
\text { [TC388430] }\end{array}$ & 0.71 & $8.15 \mathrm{E}-06$ \\
\hline uox & $\begin{array}{l}\text { ref|Danio rerio urate oxidase (uox), } \\
\text { mRNA [NM_001002332] }\end{array}$ & 0.71 & $2.61 \mathrm{E}-02$ \\
\hline myhz1.2 & $\begin{array}{l}\text { ref|Danio rerio myosin, heavy polypeptide } \\
1.2 \text {, skeletal muscle (myhz1.2), mRNA } \\
\text { [NM_001161446] }\end{array}$ & 0.71 & $1.20 \mathrm{E}-03$ \\
\hline EH438071 & $\begin{array}{l}\text { gb|FDR103-P00018-DEPE-F_K13 } \\
\text { FDR103 Danio rerio cDNA clone } \\
\text { FDR103-P00018-BR_K13 5', mRNA } \\
\text { sequence [EH438071] }\end{array}$ & 0.71 & $1.41 \mathrm{E}-02$ \\
\hline akt1s 1 & $\begin{array}{l}\text { ens|AKT1 substrate 1 (proline-rich) } \\
\text { [Source:ZFIN;Acc:ZDB-GENE-030131- } \\
\text { 482] [ENSDART00000157320] }\end{array}$ & 0.71 & $1.19 \mathrm{E}-07$ \\
\hline sult6b1 & $\begin{array}{l}\text { ref|Danio rerio sulfotransferase family, } \\
\text { cytosolic, 6b, member } 1 \text { (sult6b1), mRNA } \\
\text { [NM_214686] }\end{array}$ & 0.71 & $1.46 \mathrm{E}-05$ \\
\hline
\end{tabular}


ens|si:dkey-3h2.3

[Source:ZFIN;Acc:ZDB-GENE-070705-

\begin{tabular}{lllll} 
ENSDART00000165967 & 465] [ENSDART00000165967] & 0.70 & $5.45 \mathrm{E}-03$ \\
\hline & ref|Danio rerio CTP synthase 1b (ctps1b), & &
\end{tabular}

\begin{tabular}{|c|c|c|c|}
\hline ctps1b & mRNA [NM_001111247] & 0.70 & $2.38 \mathrm{E}-03$ \\
\hline$k d m 5 b a$ & $\begin{array}{l}\text { ref|Danio rerio lysine }(\mathrm{K}) \text {-specific } \\
\text { demethylase 5Ba }(\mathrm{kdm} 5 \mathrm{ba}), \text { mRNA } \\
\text { [NM_001347607] }\end{array}$ & 0.70 & $1.46 \mathrm{E}-05$ \\
\hline$p d k 2 b$ & $\begin{array}{l}\text { ref|Danio rerio pyruvate dehydrogenase } \\
\text { kinase, isozyme } 2 b \text { (pdk2b), mRNA } \\
{[\text { NM_200996] }}\end{array}$ & 0.70 & $3.48 \mathrm{E}-03$ \\
\hline cyp $24 a 1$ & $\begin{array}{l}\text { ref|Danio rerio cytochrome P450, family } \\
\text { 24, subfamily A, polypeptide } 1 \text { (cyp24a1), } \\
\text { mRNA [NM_001089458] }\end{array}$ & 0.70 & $2.14 \mathrm{E}-02$ \\
\hline ucp1 & $\begin{array}{l}\text { ref|Danio rerio uncoupling protein } 1 \\
\text { (ucp1), mRNA [NM_199523] }\end{array}$ & 0.69 & $1.20 \mathrm{E}-03$ \\
\hline ccl20a.3 & $\begin{array}{l}\text { ref|Danio rerio chemokine (C-C motif) } \\
\text { ligand 20a, duplicate } 3 \text { (ccl20a.3), mRNA } \\
\text { [NM_001136254] }\end{array}$ & 0.69 & 3.53E-02 \\
\hline
\end{tabular}

2 similar to protease, serine 27

ENSDART00000162027 [NP13317523] $0.69 \quad 5.56 \mathrm{E}-03$

ref|Danio rerio dehydrogenase/reductase

(SDR family) member 13 like 1

\begin{tabular}{|c|c|c|c|}
\hline dhrs13l1 & (dhrs1311), mRNA [NM_205648] & 0.68 & $1.17 \mathrm{E}-04$ \\
\hline syt5b & $\begin{array}{l}\text { ref|Danio rerio synaptotagmin } \mathrm{Vb} \text { (syt5b), } \\
\text { mRNA [NM_001020546] }\end{array}$ & 0.68 & $1.12 \mathrm{E}-02$ \\
\hline$z n f 395 a$ & $\begin{array}{l}\text { ref|Danio rerio zinc finger protein 395a } \\
\text { (znf395a), mRNA [NM_001080054] }\end{array}$ & 0.68 & 2.03E-04 \\
\hline dhrs13l1 & $\begin{array}{l}\text { ref|Danio rerio dehydrogenase/reductase } \\
\text { (SDR family) member } 13 \text { like } 1 \\
\text { (dhrs1311), mRNA [NM_205648] }\end{array}$ & 0.68 & $6.34 \mathrm{E}-03$ \\
\hline g6рса.2 & $\begin{array}{l}\text { ref|Danio rerio glucose-6-phosphatase a, } \\
\text { catalytic subunit, tandem duplicate } 2 \\
\text { (g6pca.2), mRNA [NM_001163806] }\end{array}$ & 0.67 & 7.93E-04 \\
\hline sult6b1 & $\begin{array}{l}\text { ref|Danio rerio sulfotransferase family, } \\
\text { cytosolic, } 6 \text { b, member } 1 \text { (sult6b1), mRNA } \\
\text { [NM_214686] }\end{array}$ & 0.67 & $4.89 \mathrm{E}-08$ \\
\hline$k d m 7 a a$ & $\begin{array}{l}\text { ref|Danio rerio lysine }(\mathrm{K}) \text {-specific } \\
\text { demethylase } 7 \mathrm{Aa}(\mathrm{kdm} 7 \mathrm{aa}), \text { mRNA } \\
{[\mathrm{NM} \text {-001346151] }}\end{array}$ & 0.66 & 6.13E-04 \\
\hline$z g c: 92606$ & $\begin{array}{l}\text { ref|Danio rerio zgc:92606 (zgc:92606), } \\
\text { mRNA [NM_001002707] }\end{array}$ & 0.66 & $1.02 \mathrm{E}-03$ \\
\hline ENSDART00000067461 & $\begin{array}{l}\text { ens|si:ch211-152c2.3 } \\
\text { [Source:ZFIN;Acc:ZDB-GENE-030131- } \\
\text { 9914] [ENSDART00000067461] }\end{array}$ & 0.66 & 2.43E-04 \\
\hline
\end{tabular}


ref|Danio rerio solute carrier family 25, member 55b (slc25a55b), mRNA

\begin{tabular}{|c|c|c|c|}
\hline slc $25 a 55 b$ & [NM_001003448] & 0.66 & $6.32 \mathrm{E}-05$ \\
\hline cyp1c2 & $\begin{array}{l}\text { ref|Danio rerio cytochrome P450, family } \\
\text { 1, subfamily C, polypeptide } 2 \text { (cyp1c2), } \\
\text { mRNA [NM_001114849] }\end{array}$ & 0.66 & $9.84 \mathrm{E}-03$ \\
\hline$t s c 22 d 3$ & $\begin{array}{l}\text { ref|Danio rerio TSC22 domain family, } \\
\text { member } 3 \text { (tsc22d3), transcript variant } 2 \text {, } \\
\text { mRNA [NM_001348480] }\end{array}$ & 0.66 & $1.10 \mathrm{E}-03$ \\
\hline aldocb & $\begin{array}{l}\text { ref|Danio rerio aldolase C, fructose- } \\
\text { bisphosphate, b (aldocb), mRNA } \\
\text { [NM_194384] }\end{array}$ & 0.66 & $9.03 \mathrm{E}-04$ \\
\hline agt & $\begin{array}{l}\text { ref|Danio rerio angiotensinogen (agt), } \\
\text { mRNA [NM_198063] }\end{array}$ & 0.65 & $1.06 \mathrm{E}-02$ \\
\hline p4halb & $\begin{array}{l}\text { ref|Danio rerio prolyl 4-hydroxylase, } \\
\text { alpha polypeptide I b (p4ha1b), mRNA } \\
\text { [NM_214691] }\end{array}$ & 0.65 & $5.62 \mathrm{E}-03$ \\
\hline soul4 & $\begin{array}{l}\text { tc|Rep: Predicted protein - Monosiga } \\
\text { brevicollis MX1, partial (37\%) } \\
\text { [TC434991] }\end{array}$ & 0.65 & $1.26 \mathrm{E}-05$ \\
\hline si:ch211-11n16.2 & $\begin{array}{l}\text { ens|si:ch211-11n16.2 } \\
\text { [Source:ZFIN;Acc:ZDB-GENE-041008- } \\
\text { 77] [ENSDART00000160145] }\end{array}$ & 0.65 & $3.22 \mathrm{E}-03$ \\
\hline$r d h 8 b$ & $\begin{array}{l}\text { ref|Danio rerio retinol dehydrogenase 8b } \\
\text { (rdh8b), mRNA [NM_200788] }\end{array}$ & 0.65 & $3.15 \mathrm{E}-03$ \\
\hline prr33 & $\begin{array}{l}\text { ens|proline rich } 33 \\
\text { [Source:ZFIN;Acc:ZDB-GENE-030131- } \\
\text { 5326] [ENSDART00000156828] }\end{array}$ & 0.65 & $1.85 \mathrm{E}-02$ \\
\hline tcp1112 & $\begin{array}{l}\text { ref|Danio rerio t-complex 11, testis- } \\
\text { specific-like } 2 \text { (tcp1112), mRNA } \\
\text { [NM_213020] }\end{array}$ & 0.64 & $1.30 \mathrm{E}-06$ \\
\hline eno2 & $\begin{array}{l}\text { ref|Danio rerio enolase } 2 \text { (eno2), mRNA } \\
\text { [NM_001003848] }\end{array}$ & 0.64 & $4.57 \mathrm{E}-03$ \\
\hline kif5aa & $\begin{array}{l}\text { ref|Danio rerio kinesin family member } \\
\text { 5A, a (kif5aa), mRNA [NM_001199776] }\end{array}$ & 0.64 & $1.11 \mathrm{E}-04$ \\
\hline bcl6ab & $\begin{array}{l}\text { ref|Danio rerio B cell CLL/lymphoma 6ab } \\
\text { (bcl6ab), mRNA [NM_001100074] }\end{array}$ & 0.64 & $3.04 \mathrm{E}-05$ \\
\hline myhz1.1 & $\begin{array}{l}\text { ref|Danio rerio myosin, heavy polypeptide } \\
\text { 1.1, skeletal muscle (myhz1.1), transcript } \\
\text { variant } 1, \text { mRNA [NM_001115089] }\end{array}$ & 0.64 & $1.36 \mathrm{E}-02$ \\
\hline iffola & $\begin{array}{l}\text { ens|intermediate filament family orphan } \\
\text { 1a [Source:ZFIN;Acc:ZDB-GENE- } \\
\text { 060503-418] [ENSDART00000091615] }\end{array}$ & 0.63 & $9.11 \mathrm{E}-03$ \\
\hline$t s c 22 d 2$ & $\begin{array}{l}\text { ref|Danio rerio TSC22 domain family } 2 \\
\text { (tsc22d2), mRNA [NM_200109] }\end{array}$ & 0.63 & $4.32 \mathrm{E}-06$ \\
\hline
\end{tabular}


ref|Danio rerio solute carrier family 35, member G2b (slc35g2b), mRNA

\begin{tabular}{|c|c|c|c|}
\hline slc35g2b & [NM_001013563] & 0.63 & $1.57 \mathrm{E}-03$ \\
\hline rgma & $\begin{array}{l}\text { tc|GB|BC165864.1|AAI65864.1 Unknown } \\
\text { (protein for MGC:192952) [NP13228499] }\end{array}$ & 0.63 & $2.36 \mathrm{E}-04$ \\
\hline tmem59l & $\begin{array}{l}\text { ref|Danio rerio transmembrane protein 59- } \\
\text { like (tmem59l), mRNA [NM_213337] }\end{array}$ & 0.63 & $2.12 \mathrm{E}-05$ \\
\hline slc12a7b & $\begin{array}{l}\text { ens|solute carrier family } 12 \\
\text { (potassium/chloride transporter), member } \\
\text { 7b [Source:ZFIN;Acc:ZDB-GENE- } \\
\text { 030829-61] [ENSDART00000134251] }\end{array}$ & 0.62 & $8.26 \mathrm{E}-04$ \\
\hline$m f s d 4 a b$ & $\begin{array}{l}\text { ref|Danio rerio major facilitator } \\
\text { superfamily domain containing } 4 \mathrm{Ab} \\
\text { (mfsd4ab), mRNA [NM_001114416] }\end{array}$ & 0.62 & $9.36 \mathrm{E}-03$ \\
\hline clpxb & $\begin{array}{l}\text { ens|caseinolytic mitochondrial matrix } \\
\text { peptidase chaperone subunit b } \\
\text { [Source:ZFIN;Acc:ZDB-GENE-130404- } \\
\text { 1] [ENSDART00000153827] }\end{array}$ & 0.62 & $1.17 \mathrm{E}-02$ \\
\hline slc7a8a & $\begin{array}{l}\text { ref|Danio rerio solute carrier family } 7 \\
\text { (amino acid transporter light chain, L } \\
\text { system), member 8a (slc7a8a), mRNA } \\
\text { [NM_001271897] }\end{array}$ & 0.62 & $2.39 \mathrm{E}-03$ \\
\hline bcl6aa & $\begin{array}{l}\text { ref|Danio rerio B cell CLL/lymphoma 6aa } \\
\text { (bcl6aa), mRNA [NM_200734] }\end{array}$ & 0.62 & $1.12 \mathrm{E}-02$ \\
\hline opn6a & $\begin{array}{l}\text { ref|Danio rerio opsin 6, group member a } \\
\text { (opn6a), mRNA [NM_001079657] }\end{array}$ & 0.62 & $7.50 \mathrm{E}-03$ \\
\hline ethe1 & $\begin{array}{l}\text { ref|Danio rerio ethylmalonic } \\
\text { encephalopathy } 1 \text { (ethe1), mRNA } \\
\text { [NM_212929] }\end{array}$ & 0.61 & 3.43E-03 \\
\hline myhz2 & Unknown & 0.61 & $5.71 \mathrm{E}-03$ \\
\hline myhz1.1 & $\begin{array}{l}\text { ref|Danio rerio myosin, heavy polypeptide } \\
\text { 1.1, skeletal muscle (myhz1.1), transcript } \\
\text { variant } 1, \text { mRNA [NM_001115089] }\end{array}$ & 0.61 & $1.93 \mathrm{E}-02$ \\
\hline brip1 & $\begin{array}{l}\text { ref|Danio rerio BRCA1 interacting protein } \\
\text { C-terminal helicase } 1 \text { (brip1), mRNA } \\
\text { [NM_001110296] }\end{array}$ & 0.61 & $1.80 \mathrm{E}-02$ \\
\hline$B C 154660$ & Unknown & 0.61 & $1.04 \mathrm{E}-04$ \\
\hline ppdpfa & $\begin{array}{l}\text { gb|FDR103-P00062-DEPE-R_K11 } \\
\text { FDR103 Danio rerio cDNA clone } \\
\text { FDR103-P00062-BR_K11 3', mRNA } \\
\text { sequence [EH479777] }\end{array}$ & 0.61 & $1.28 \mathrm{E}-02$ \\
\hline mpeg1.3 & $\begin{array}{l}\text { ref|Danio rerio macrophage expressed 1, } \\
\text { tandem duplicate } 3 \text { (mpeg1.3), mRNA } \\
\text { [NM_001123310] }\end{array}$ & 0.61 & $1.32 \mathrm{E}-03$ \\
\hline
\end{tabular}


ref|Danio rerio myosin binding protein $\mathrm{C}$,

fast type $b$ (mybpc2b), mRNA

\begin{tabular}{|c|c|c|c|}
\hline mybpc $2 b$ & [NM_001013511] & 0.61 & $2.24 \mathrm{E}-04$ \\
\hline castor2 & $\begin{array}{l}\text { ref|Danio rerio cytosolic arginine sensor } \\
\text { for mTORC1 subunit } 2 \text { (castor2), mRNA } \\
\text { [NM_199780] }\end{array}$ & 0.61 & $1.20 \mathrm{E}-03$ \\
\hline ryr3 & $\begin{array}{l}\text { ens|ryanodine receptor } 3 \\
\text { [Source:ZFIN;Acc:ZDB-GENE-041001- } \\
\text { 165] [ENSDART00000172634] }\end{array}$ & 0.61 & $2.10 \mathrm{E}-02$ \\
\hline $\operatorname{cr} x$ & $\begin{array}{l}\text { ref|Danio rerio cone-rod homeobox (crx), } \\
\text { mRNA [NM_152940] }\end{array}$ & 0.60 & 7.93E-03 \\
\hline rpe65a & $\begin{array}{l}\text { ref|Danio rerio retinal pigment epithelium- } \\
\text { specific protein 65a (rpe65a), mRNA } \\
\text { [NM_200751] }\end{array}$ & 0.60 & $3.91 \mathrm{E}-02$ \\
\hline$z g c: 92606$ & $\begin{array}{l}\text { ref|Danio rerio zgc:92606 (zgc:92606), } \\
\text { mRNA [NM_001002707] }\end{array}$ & 0.60 & $1.39 \mathrm{E}-03$ \\
\hline $\operatorname{lin} 7 b$ & $\begin{array}{l}\text { ref|Danio rerio lin-7 homolog B (C. } \\
\text { elegans) (lin7b), mRNA } \\
\text { [NM_001020733] }\end{array}$ & 0.60 & $2.52 \mathrm{E}-03$ \\
\hline abila & $\begin{array}{l}\text { ref|Danio rerio abl-interactor 1a (abi1a), } \\
\text { mRNA [NM_001328427] }\end{array}$ & 0.60 & $1.41 \mathrm{E}-02$ \\
\hline ENSDART00000092493 & $\begin{array}{l}\text { ens|protein tyrosine phosphatase, receptor } \\
\text { type, t [Source:ZFIN;Acc:ZDB-GENE- } \\
101028-4 \text { ] [ENSDART00000092493] }\end{array}$ & 0.60 & $8.33 \mathrm{E}-03$ \\
\hline orc4 & $\begin{array}{l}\text { ref|Danio rerio origin recognition } \\
\text { complex, subunit } 4 \text { (orc4), mRNA } \\
\text { [NM_213183] }\end{array}$ & -0.60 & $2.23 \mathrm{E}-03$ \\
\hline EH440809 & $\begin{array}{l}\text { gb|FDR103-P00026-DEPE-F_E19 } \\
\text { FDR103 Danio rerio cDNA clone } \\
\text { FDR103-P00026-BR_E19 5', mRNA } \\
\text { sequence [EH440809] }\end{array}$ & -0.60 & $2.33 \mathrm{E}-03$ \\
\hline odc1 & $\begin{array}{l}\text { ref|Danio rerio ornithine decarboxylase } 1 \\
\text { (odc1), mRNA [NM_131801] }\end{array}$ & -0.61 & $4.25 \mathrm{E}-03$ \\
\hline $\operatorname{tma} 7$ & $\begin{array}{l}\text { ref|Danio rerio translation machinery } \\
\text { associated } 7 \text { homolog (tma7), mRNA } \\
\text { [NM_001159834] }\end{array}$ & -0.61 & $1.29 \mathrm{E}-02$ \\
\hline$z g c: 153665$ & $\begin{array}{l}\text { ref|Danio rerio zgc:153665 (zgc:153665), } \\
\text { mRNA [NM_001077463] }\end{array}$ & -0.61 & $2.14 \mathrm{E}-03$ \\
\hline mrpl16 & $\begin{array}{l}\text { ref|Danio rerio mitochondrial ribosomal } \\
\text { protein L16 (mrpl16), mRNA } \\
\text { [NM_001007764] }\end{array}$ & -0.61 & $3.24 \mathrm{E}-03$ \\
\hline anxalb & $\begin{array}{l}\text { ref|Danio rerio annexin A1b (anxa1b), } \\
\text { mRNA [NM_181759] }\end{array}$ & -0.61 & 3.73E-03 \\
\hline rnasel3 & $\begin{array}{l}\text { ref|Danio rerio ribonuclease like } 3 \\
\text { (rnasel3), mRNA [NM_001099453] }\end{array}$ & -0.61 & $4.50 \mathrm{E}-03$ \\
\hline
\end{tabular}


ref|Danio rerio zinc finger protein 410

\begin{tabular}{|c|c|c|c|}
\hline$z n f 410$ & (znf410), mRNA [NM_205653] & -0.61 & $1.22 \mathrm{E}-02$ \\
\hline naalad2 & $\begin{array}{l}\text { ref|Danio rerio N-acetylated alpha-linked } \\
\text { acidic dipeptidase } 2 \text { (naalad2), mRNA } \\
\text { [NM_200277] }\end{array}$ & -0.61 & $1.53 \mathrm{E}-04$ \\
\hline psma5 & $\begin{array}{l}\text { ref|Danio rerio proteasome subunit alpha } \\
5 \text { (psma5), mRNA [NM_205708] }\end{array}$ & -0.62 & $1.16 \mathrm{E}-05$ \\
\hline si:ch73-347e22.8 & $\begin{array}{l}\text { ens|si:ch73-347e22.8 } \\
\text { [Source:ZFIN;Acc:ZDB-GENE-030131- } \\
\text { 8455] [ENSDART00000168968] }\end{array}$ & -0.62 & 2.43E-04 \\
\hline hells & $\begin{array}{l}\text { ref|Danio rerio helicase, lymphoid specific } \\
\text { (hells), mRNA [NM_001037101] }\end{array}$ & -0.62 & $3.58 \mathrm{E}-03$ \\
\hline$z g c: 194839$ & $\begin{array}{l}\text { ref|Danio rerio zgc:194839 (zgc:194839), } \\
\text { mRNA [NM_001123324] }\end{array}$ & -0.62 & $1.38 \mathrm{E}-03$ \\
\hline mboat1 & $\begin{array}{l}\text { ens|membrane bound O-acyltransferase } \\
\text { domain containing 1 } \\
\text { [Source:ZFIN;Acc:ZDB-GENE-041114- } \\
\text { 98] [ENSDART00000141860] }\end{array}$ & -0.63 & 3.06E-04 \\
\hline$w u: f c 14 h 11$ & $\begin{array}{l}\text { gb|AGENCOURT_16619286 } \\
\text { NIH_ZGC_7 Danio rerio cDNA clone } \\
\text { IMAGE:7052511 5', mRNA sequence } \\
\text { [CK028151] }\end{array}$ & -0.63 & 3.35E-02 \\
\hline$c a 15 c$ & $\begin{array}{l}\text { ref|Danio rerio carbonic anhydrase XV c } \\
\text { (ca15c), mRNA [NM_001077333] }\end{array}$ & -0.63 & $5.14 \mathrm{E}-04$ \\
\hline tomm20a & $\begin{array}{l}\text { ref|Danio rerio translocase of outer } \\
\text { mitochondrial membrane } 20 \text { (tomm20a), } \\
\text { mRNA [NM_213036] }\end{array}$ & -0.63 & 4.33E-02 \\
\hline hsp90aal.1 & $\begin{array}{l}\text { ref|Danio rerio heat shock protein } 90, \\
\text { alpha (cytosolic), class A member 1, } \\
\text { tandem duplicate } 1 \text { (hsp90aa1.1), mRNA } \\
\text { [NM_131328] }\end{array}$ & -0.63 & 4.37E-03 \\
\hline anxa3a & $\begin{array}{l}\text { ens|annexin A3a [Source:ZFIN;Acc:ZDB- } \\
\text { GENE-040912-58] } \\
\text { [ENSDART00000192044] }\end{array}$ & -0.63 & $5.22 \mathrm{E}-04$ \\
\hline mboat1 & $\begin{array}{l}\text { ens|membrane bound O-acyltransferase } \\
\text { domain containing 1 } \\
\text { [Source:ZFIN;Acc:ZDB-GENE-041114- } \\
\text { 98] [ENSDART00000141860] }\end{array}$ & -0.63 & $2.16 \mathrm{E}-05$ \\
\hline si:ch211-201h21.5 & $\begin{array}{l}\text { ref|Danio rerio si:ch211-201h21.5 } \\
\text { (si:ch211-201h21.5), mRNA } \\
\text { [NM_001030089] }\end{array}$ & -0.63 & $9.29 \mathrm{E}-04$ \\
\hline NP13316691 & $\begin{array}{l}\text { tc|GB|XM_001344782.2|XP_001344818. } \\
2 \text { similar to predicted protein } \\
\text { [NP13316691] }\end{array}$ & -0.63 & $2.66 \mathrm{E}-02$ \\
\hline
\end{tabular}


ref|Danio rerio si:ch211-131k2.3

(si:ch211-131k2.3), mRNA

si:ch211-131k2.3

[NM_001326711]

$-0.63 \quad 2.83 \mathrm{E}-04$

ref|Danio rerio IMP3, U3 small nucleolar

ribonucleoprotein, homolog (yeast)

imp3

(imp3), mRNA [NM_001291357]

$-0.64 \quad 4.22 \mathrm{E}-04$

ens|si:dkey-172k15.3

[Source:ZFIN;Acc:ZDB-GENE-131121-

si:dkey-172k15.13

97] [ENSDART00000155070]

$-0.64 \quad 3.40 \mathrm{E}-03$

ref|Danio rerio secreted frizzled-related

protein $1 \mathrm{~b}$ (sfrp1b), mRNA

sfrplb

[NM_001083571]

$-0.64 \quad 1.13 \mathrm{E}-02$

ens|si:ch211-57i17.2

[Source:ZFIN;Acc:ZDB-GENE-041014-

ENSDART00000153065 258] [ENSDART00000153065]

ens|si:ch73-269m23.5

[Source:ZFIN;Acc:ZDB-GENE-110411-

si:ch73-269m23.5

68] [ENSDART00000148669]

$-0.64 \quad 4.76 \mathrm{E}-03$

$\mathrm{gb} \mid \mathrm{ft} 33 \mathrm{c} 11 . y 1$ Gong zebrafish testis Danio

rerio cDNA clone IMAGE:5152508 5',

BI673044

mRNA sequence [BI673044]

$-0.64 \quad 1.34 \mathrm{E}-02$

ref|Danio rerio ornithine decarboxylase 1

odc1

(odc1), mRNA [NM_131801]

$-0.65 \quad 3.58 \mathrm{E}-03$

ref|Danio rerio ELOVL fatty acid

elongase $8 \mathrm{~b}$ (elovl8b), transcript variant 1 ,

elovl8b

mRNA [NM_001024438]

$-0.65 \quad 1.16 \mathrm{E}-03$

ref|Danio rerio origin recognition

complex, subunit 3 (orc3), mRNA

orc3

[NM_212727]

$-0.65 \quad 1.72 \mathrm{E}-05$

ref|Danio rerio uncoupling protein 3

ucp3

(ucp3), mRNA [NM_200353]

$-0.65 \quad 4.88 \mathrm{E}-02$

ref|Danio rerio zgc:77739 (zgc:77739),

zgc:77739

mRNA [NM_200896]

$-0.65 \quad 3.69 \mathrm{E}-02$

ref|Danio rerio globoside alpha-1,3-N-

acetylgalactosaminyltransferase 1 , like 4

$\underline{\text { gbgt114 }}$

(gbgt114), mRNA [NM_200125]

ref|Danio rerio replication protein A2

rpa2

(rpa2), mRNA [NM_131711]

$-0.65 \quad 4.57 \mathrm{E}-03$

ref|Danio rerio calpain 9 (capn9), mRNA

capn9

[NM_001003501]

$-0.66 \quad 2.49 \mathrm{E}-04$

ref|Danio rerio ferritin, heavy

polypeptide-like 31 (fthl31), mRNA

fthl31

[NM_001020531]

$-0.66 \quad 3.89 \mathrm{E}-03$

gb|FDR306-P00011-DEPE-F_K17

wu:fj88f11

FDR306 Danio rerio cDNA clone

$-0.66 \quad 3.65 \mathrm{E}-03$ 
FDR306-P00011-BR_K17 5', mRNA

sequence [EH582267]

ref|Danio rerio ADP-ribosylation factor $2 \mathrm{~b}$

(arf2b), mRNA [NM_201480] $\quad-0.66 \quad 3.55 \mathrm{E}-02$

ref|Danio rerio si:ch211-244o22.2

(si:ch211-244o22.2), mRNA

si:ch211-244o22.2

[NM_001082823]

$-0.67 \quad 1.49 \mathrm{E}-06$

ens|zgc:153921 [Source:ZFIN;Acc:ZDB-

GENE-060929-816]

LOC791500

[ENSDART00000011111]

$-0.67 \quad 1.58 \mathrm{E}-02$

ref|Danio rerio claudin e (cldne), mRNA

\begin{tabular}{|c|c|c|c|}
\hline cldne & [NM_131765] & -0.67 & $1.87 \mathrm{E}-04$ \\
\hline krt99 & $\begin{array}{l}\text { ref|Danio rerio keratin } 99 \text { (krt99), mRNA } \\
\text { [NM_001017588] }\end{array}$ & -0.68 & $6.18 \mathrm{E}-03$ \\
\hline$s m x 5$ & $\begin{array}{l}\text { ref|Danio rerio smx5 (smx5), mRNA } \\
\text { [NM_131496] }\end{array}$ & -0.68 & $1.68 \mathrm{E}-04$ \\
\hline $\operatorname{gch} 2$ & $\begin{array}{l}\text { ref|Danio rerio GTP cyclohydrolase } 2 \\
\text { (gch2), mRNA [NM_131667] }\end{array}$ & -0.69 & $1.25 \mathrm{E}-02$ \\
\hline
\end{tabular}

ens|nuclear prelamin A recognition factor

[Source:ZFIN;Acc:ZDB-GENE-040718-

\begin{tabular}{|c|c|c|c|}
\hline narf & 31] [ENSDART00000007053] & -0.69 & $1.31 \mathrm{E}-03$ \\
\hline pmm2 2 & $\begin{array}{l}\text { ref|Danio rerio phosphomannomutase } 2 \\
\text { (pmm2), mRNA [NM_200084] }\end{array}$ & -0.69 & 3.93E-04 \\
\hline socsla & $\begin{array}{l}\text { ref|Danio rerio suppressor of cytokine } \\
\text { signaling 1a (socs1a), mRNA } \\
\text { [NM_001003467] }\end{array}$ & -0.69 & 2.61E-05 \\
\hline si:ch1073-126c3.2 & $\begin{array}{l}\text { ref|Danio rerio si:ch1073-126c3.2 } \\
\text { (si:ch1073-126c3.2), mRNA } \\
\text { [NM_001144786] }\end{array}$ & -0.69 & $2.63 \mathrm{E}-02$ \\
\hline & $\begin{array}{l}\text { ref|PREDICTED: Danio rerio } \\
\text { uncharacterized LOC100537502 } \\
\text { (LOC100537502), mRNA }\end{array}$ & 070 & $356 \mathrm{~F}-02$ \\
\hline TC418621 & $\begin{array}{l}{\left[\mathrm{XM} \_003200273\right]} \\
\text { ref|Danio rerio ubiquitin-like with PHD }\end{array}$ & -0.70 & $3.56 \mathrm{E}-02$ \\
\hline uhrf1 & $\begin{array}{l}\text { and ring finger domains } 1 \text { (uhrf1), mRNA } \\
\text { [NM_213077] }\end{array}$ & -0.70 & $3.20 \mathrm{E}-04$ \\
\hline pcna & Unknown & -0.70 & $1.97 \mathrm{E}-02$ \\
\hline $\operatorname{ly} 6 m 5$ & $\begin{array}{l}\text { ens|lymphocyte antigen } 6 \text { family member } \\
\text { M5 [Source:ZFIN;Acc:ZDB-GENE- } \\
\text { 131127-265] [ENSDART00000170587] }\end{array}$ & -0.70 & $1.89 \mathrm{E}-02$ \\
\hline dao.1 & $\begin{array}{l}\text { ref|Danio rerio D-amino-acid oxidase, } \\
\text { tandem duplicate } 1 \text { (dao.1), mRNA } \\
\text { [NM_001033740] }\end{array}$ & -0.70 & $1.08 \mathrm{E}-02$ \\
\hline zgc:153284 & $\begin{array}{l}\text { ref|Danio rerio zgc: } 153284(\mathrm{zgc}: 153284) \text {, } \\
\text { transcript variant 1, mRNA } \\
\text { [NM_001291936] }\end{array}$ & -0.70 & $8.06 \mathrm{E}-05$ \\
\hline
\end{tabular}


ref|Danio rerio zgc:153665 (zgc:153665),

ref|Danio rerio interleukin 4 receptor, tandem duplicate 1 (il4r.1), mRNA

il4r.1

[NM_001013282]

$-0.71 \quad 1.98 \mathrm{E}-02$

gb|AGENCOURT_90073624

NIH_ZGC_29 Danio rerio cDNA clone

IMAGE:8815158 5', mRNA sequence

EE697538

[EE697538]

$-0.71 \quad 1.30 \mathrm{E}-03$

ref|Danio rerio sciellin (scel), mRNA

\begin{tabular}{ll} 
scel & {$[$ NM_001005304] } \\
\hline & ref(Danio rerio dihydrofolate reductase
\end{tabular}

\begin{tabular}{ll}
$\boldsymbol{d} \boldsymbol{h} \boldsymbol{f r}$ & (dhfr), mRNA [NM_131775] \\
\hline & ref|Danio rerio ribonucleotide reductase
\end{tabular}

M2 polypeptide (rrm2), mRNA

rrm2

[NM_131450]

$-0.71 \quad 4.21 \mathrm{E}-04$

tc|Rep: Predicted protein - Monosiga

TC431279

brevicollis MX1, partial (3\%) [TC431279]

$-0.71 \quad 1.31 \mathrm{E}-02$

ens/interleukin 4 receptor, tandem

duplicate 1 [Source:ZFIN;Acc:ZDB-

GENE-050227-5]

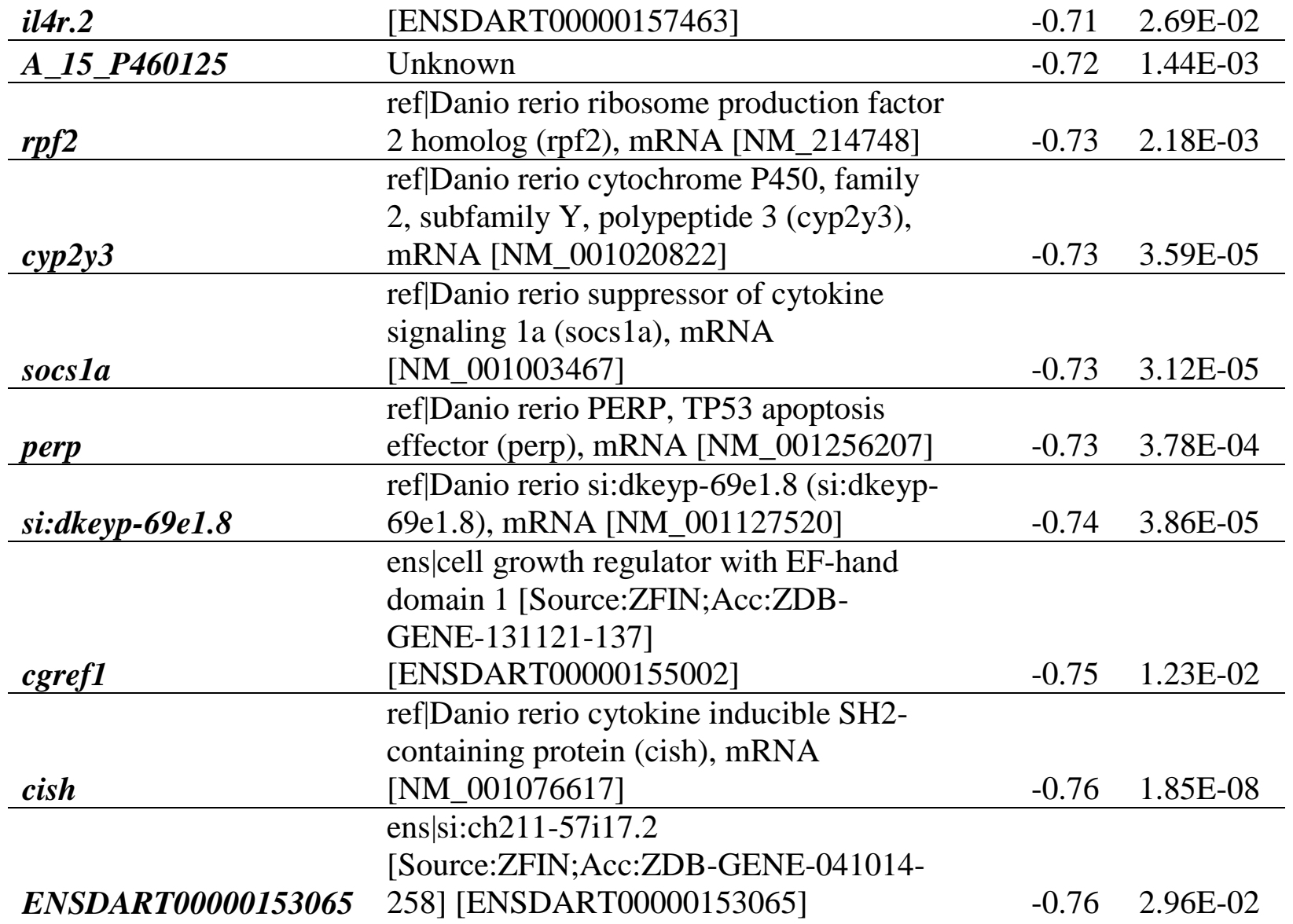


ref|Danio rerio odorant receptor, family D, subfamily 109, member 5 (or109-5),

\begin{tabular}{|c|c|c|c|}
\hline or109-5 & mRNA [NM_001130807] & -0.76 & $3.80 \mathrm{E}-02$ \\
\hline chrac1 & $\begin{array}{l}\text { tc|GB|BC164918.1|AAI64918.1 } \\
\text { zgc:110753 protein [NP13229156] }\end{array}$ & -0.77 & $1.01 \mathrm{E}-03$ \\
\hline si:ch211-157c3.4 & $\begin{array}{l}\text { ref|Danio rerio si:ch211-157c3.4 } \\
\text { (si:ch211-157c3.4), mRNA } \\
\text { [NM_001164368] }\end{array}$ & -0.78 & $2.72 \mathrm{E}-04$ \\
\hline zgc:162193 & $\begin{array}{l}\text { ref|Danio rerio zgc:162193 (zgc:162193), } \\
\text { mRNA [NM_001089327] }\end{array}$ & -0.78 & $1.02 \mathrm{E}-04$ \\
\hline zgc:101716 & Unknown & -0.79 & $1.40 \mathrm{E}-02$ \\
\hline frg1 1 & $\begin{array}{l}\text { ref|Danio rerio FSHD region gene } 1 \\
\text { (frg1), mRNA [NM_001017793] }\end{array}$ & -0.79 & $2.15 \mathrm{E}-02$ \\
\hline kcnj1a.2 & $\begin{array}{l}\text { ref|Danio rerio potassium inwardly- } \\
\text { rectifying channel, subfamily J, member } \\
\text { 1a, tandem duplicate } 2 \text { (kcnj1a.2), mRNA } \\
\text { [NM_001014312] }\end{array}$ & -0.80 & $3.55 \mathrm{E}-07$ \\
\hline NP9868346 & $\begin{array}{l}\text { tc|GB|XM_688888.1|XP_693980.1 } \\
\text { hypothetical protein [NP9868346] }\end{array}$ & -0.80 & $2.20 \mathrm{E}-03$ \\
\hline DV599636 & $\begin{array}{l}\text { gb|AGENCOURT_61885554 } \\
\text { NIH_ZGC_14 Danio rerio cDNA clone } \\
\text { IMAGE:8152191 5', mRNA sequence } \\
\text { [DV599636] }\end{array}$ & -0.81 & $9.48 \mathrm{E}-03$ \\
\hline kcnj1a.5 & $\begin{array}{l}\text { ref|Danio rerio potassium inwardly- } \\
\text { rectifying channel, subfamily J, member } \\
\text { 1a, tandem duplicate } 5 \text { (kcnj1a.5), mRNA } \\
\text { [NM_001045169] }\end{array}$ & -0.81 & $2.00 \mathrm{E}-05$ \\
\hline si:ch211-131k2.3 & $\begin{array}{l}\text { ref|Danio rerio si:ch211-131k2.3 } \\
\text { (si:ch211-131k2.3), mRNA } \\
\text { [NM_001326711] }\end{array}$ & -0.81 & 2.53E-04 \\
\hline ntrk1 & $\begin{array}{l}\text { ref|Danio rerio neurotrophic tyrosine } \\
\text { kinase, receptor, type } 1 \text { (ntrk1), mRNA } \\
\text { [NM_001301356] }\end{array}$ & -0.82 & $4.58 \mathrm{E}-03$ \\
\hline pkn1a & $\begin{array}{l}\text { gb|CT725606 ZF_mu Danio rerio cDNA } \\
\text { clone ZF_mu_212o05 3', mRNA } \\
\text { sequence [CT725606] }\end{array}$ & -0.83 & $1.97 \mathrm{E}-03$ \\
\hline cishb & $\begin{array}{l}\text { ref|Danio rerio cytokine inducible SH2- } \\
\text { containing protein b (cishb), mRNA } \\
\text { [NM_001114554] }\end{array}$ & -0.83 & 3.75E-07 \\
\hline fosab & $\begin{array}{l}\text { ref|Danio rerio v-fos FBJ murine } \\
\text { osteosarcoma viral oncogene homolog Ab } \\
\text { (fosab), mRNA [NM_205569] }\end{array}$ & -0.83 & $1.85 \mathrm{E}-03$ \\
\hline zgc: 174938 & $\begin{array}{l}\text { ref|Danio rerio zgc:174938 (zgc:174938), } \\
\text { mRNA [NM_001105700] }\end{array}$ & -0.83 & $1.13 \mathrm{E}-03$ \\
\hline
\end{tabular}


tc|Rep: LOC553461 protein - Danio rerio

(Zebrafish) (Brachydanio rerio), complete

si:dkey-147f3.4

[TC373254]

$-0.85 \quad 8.37 \mathrm{E}-03$

ref|Danio rerio GTP cyclohydrolase 2

gch2

(gch2), mRNA [NM_131667]

$-0.86 \quad 1.50 \mathrm{E}-03$

ref|Danio rerio cystatin 14b, tandem

duplicate 1 (cst14b.1), mRNA

cst14b.1

[NM_001077274]

$-0.87 \quad 5.19 \mathrm{E}-04$

ref|Danio rerio SWI5 homologous

recombination repair protein (swi5),

swi5

mRNA [NM_001326527]

$-0.87 \quad 1.53 \mathrm{E}-02$

ens|DnaJ heat shock protein family

(Hsp40) member A4 [Source:HGNC

Symbol;Acc:HGNC:14885]

ENSDART00000073440

[ENSDART00000073440]

ref|Danio rerio zgc:174938 (zgc:174938),

zgc:174938

mRNA [NM_001105700]

$-0.88 \quad 8.00 \mathrm{E}-03$

ref|Danio rerio si:ch211-201h21.5

(si:ch211-201h21.5), mRNA

si:ch211-201h21.5

[NM_001030089]

$-0.88 \quad 1.33 \mathrm{E}-05$

ref|Danio rerio si:dkey-52p2.5 (si:dkey-

\begin{tabular}{ll} 
si:dkey-52p2.5 & 52p2.5), mRNA [NM_001327887] \\
\hline ens|microfibril associated protein 4
\end{tabular}

[Source:HGNC

Symbol;Acc:HGNC:7035]

si:zfos-2330d3.8

[ENSDART00000171552]

$-0.90 \quad 2.20 \mathrm{E}-02$

ref|Danio rerio si:ch211-157c3.4

(si:ch211-157c3.4), mRNA

si:ch211-157c3.4

[NM_001164368]

$-0.91 \quad 4.66 \mathrm{E}-04$

ref|Danio rerio cytokine inducible SH2-

containing protein (cish), mRNA

cish

[NM_001076617]

$-0.92 \quad 1.94 \mathrm{E}-07$

gb|CT661491 ZF_mu Danio rerio cDNA

clone ZF_mu_122f15 5', mRNA sequence

ENSDART00000193104

[CT661491]

$-0.92 \quad 2.29 \mathrm{E}-03$

ref|Danio rerio testis specific, 10 (tsga10),

tsga10

mRNA [NM_001077289]

gb|CT661491 ZF_mu Danio rerio cDNA

$-0.92 \quad 8.67 \mathrm{E}-03$

clone ZF_mu_122f15 5', mRNA sequence

si:busm1-172k9.2

[CT661491]

$-0.94 \quad 1.66 \mathrm{E}-02$

ens|si:dkey-222b8.1

[Source:ZFIN;Acc:ZDB-GENE-060503-

si:dkey-222b8.1

248] [ENSDART00000139040]

$-0.95 \quad 2.53 \mathrm{E}-04$

hsp90aa1.1

ref|Danio rerio heat shock protein 90,

alpha (cytosolic), class A member 1,

$-0.95 \quad 2.09 \mathrm{E}-04$ 
tandem duplicate 1 (hsp90aa1.1), mRNA

[NM_131328]

ref|Danio rerio actinin, alpha $2 b$ (actn2b),

\begin{tabular}{|c|c|c|c|}
\hline$a c t n 2 b$ & $\begin{array}{l}\text { ref|Danio rerio actinin, alpha 2b (actn2b), } \\
\text { mRNA [NM_001037573] }\end{array}$ & -0.96 & $2.98 \mathrm{E}-02$ \\
\hline ENSDART00000122435 & $\begin{array}{l}\text { tc|GB|XM_001345917.2|XP_001345953. } \\
2 \text { similar to GTPase, IMAP family } \\
\text { member } 8 \text { [NP13315638] }\end{array}$ & -0.97 & $2.34 \mathrm{E}-03$ \\
\hline NP13316011 & $\begin{array}{l}\text { tc|GB|XM_001921709.1|XP_001921744. } \\
1 \text { similar to polyprotein [NP13316011] }\end{array}$ & -0.97 & $5.31 \mathrm{E}-03$ \\
\hline zgc:158846 & $\begin{array}{l}\text { ref|Danio rerio zgc:158846 (zgc:158846), } \\
\text { mRNA [NM_001083023] }\end{array}$ & -0.98 & 4.44E-03 \\
\hline cishb & $\begin{array}{l}\text { ref|Danio rerio cytokine inducible SH2- } \\
\text { containing protein b (cishb), mRNA } \\
\text { [NM_001114554] }\end{array}$ & -1.00 & $1.29 \mathrm{E}-05$ \\
\hline unc5c & $\begin{array}{l}\text { ref|Danio rerio unc-5 netrin receptor C } \\
\text { (unc5c), mRNA [NM_001099984] }\end{array}$ & -1.02 & $2.14 \mathrm{E}-03$ \\
\hline ENSDART00000153065 & $\begin{array}{l}\text { ens|si:ch211-57i17.2 } \\
\text { [Source:ZFIN;Acc:ZDB-GENE-041014- } \\
\text { 258] [ENSDART00000153065] }\end{array}$ & -1.02 & 7.44E-03 \\
\hline $\arg 2$ & $\begin{array}{l}\text { ref|Danio rerio arginase } 2(\arg 2), \text { mRNA } \\
\text { [NM_199611] }\end{array}$ & -1.05 & $6.80 \mathrm{E}-08$ \\
\hline LOC100004427 & $\begin{array}{l}\text { ens|serine protease 27-like [Source:NCBI } \\
\text { gene;Acc:100004427] } \\
\text { [ENSDART00000162248] }\end{array}$ & -1.05 & $2.90 \mathrm{E}-03$ \\
\hline cish & $\begin{array}{l}\text { ref|Danio rerio cytokine inducible SH2- } \\
\text { containing protein (cish), mRNA } \\
\text { [NM_001076617] }\end{array}$ & -1.06 & 4.11E-06 \\
\hline si:ch211-157c3.4 & $\begin{array}{l}\text { ref|Danio rerio si:ch211-157c3.4 } \\
\text { (si:ch211-157c3.4), mRNA } \\
\text { [NM_001164368] }\end{array}$ & -1.08 & $1.53 \mathrm{E}-06$ \\
\hline vipr2 & $\begin{array}{l}\text { ref|Danio rerio vasoactive intestinal } \\
\text { peptide receptor } 2 \text { (vipr2), mRNA } \\
\text { [NM_131779] }\end{array}$ & -1.09 & $1.90 \mathrm{E}-03$ \\
\hline TC396001 & Unknown & -1.13 & $1.99 \mathrm{E}-02$ \\
\hline si:ch211-157c3.4 & $\begin{array}{l}\text { ref|Danio rerio si:ch211-157c3.4 } \\
\text { (si:ch211-157c3.4), mRNA } \\
\text { [NM_001164368] }\end{array}$ & -1.15 & $3.40 \mathrm{E}-05$ \\
\hline kcnjla.2 & $\begin{array}{l}\text { tc|Rep: Zgc:113361 - Danio rerio } \\
\text { (Zebrafish) (Brachydanio rerio), complete } \\
\text { [TC369963] }\end{array}$ & -1.16 & $9.58 \mathrm{E}-08$ \\
\hline fkbp4 & $\begin{array}{l}\text { ref|Danio rerio FK506 binding protein } 4 \\
\text { (fkbp4), mRNA [NM_201469] }\end{array}$ & -1.16 & $1.27 \mathrm{E}-04$ \\
\hline smtlb & $\begin{array}{l}\text { ref|Danio rerio somatolactin beta (smtlb), } \\
\text { mRNA [NM_001037674] }\end{array}$ & -1.20 & 3.94E-03 \\
\hline
\end{tabular}


gb|PREDICTED: Danio rerio hypothetical protein LOC559800 (LOC559800),

\begin{tabular}{|c|c|c|c|}
\hline arsj & mRNA [XM_683173] & -1.20 & $5.60 \mathrm{E}-03$ \\
\hline sb:cb311 & $\begin{array}{l}\text { gb|ZF101-P00078-DEPE-F3_A22 } \\
\text { GISZF101 Danio rerio cDNA clone } \\
\text { IMAGE:7163616 5', mRNA sequence } \\
\text { [CK697995] }\end{array}$ & -1.28 & 2.24E-02 \\
\hline cish & $\begin{array}{l}\text { ref|Danio rerio cytokine inducible SH2- } \\
\text { containing protein (cish), mRNA } \\
\text { [NM_001076617] }\end{array}$ & -1.29 & 1.13E-09 \\
\hline$n l r c 3 l$ & $\begin{array}{l}\text { ens|NLR family, CARD domain } \\
\text { containing 3-like } \\
\text { [Source:ZFIN;Acc:ZDB-GENE-121214- } \\
\text { 346] [ENSDART00000186320] }\end{array}$ & -1.33 & $1.64 \mathrm{E}-03$ \\
\hline$z g c: 158846$ & $\begin{array}{l}\text { ref|Danio rerio zgc:158846 (zgc:158846), } \\
\text { mRNA [NM_001083023] }\end{array}$ & -1.44 & $1.20 \mathrm{E}-02$ \\
\hline ctsll & $\begin{array}{l}\text { ref|Danio rerio cathepsin L, like (ctsll), } \\
\text { mRNA [NM_001005999] }\end{array}$ & -1.58 & 4.11E-03 \\
\hline $\begin{array}{l}w u: f b 36 g 0 \\
2\end{array}$ & $\begin{array}{l}\text { gb|ZF101-P00073-DEPE-F2_G05 } \\
\text { GISZF101 Danio rerio cDNA clone } \\
\text { IMAGE:7161823 5', mRNA sequence } \\
\text { [CK696476] }\end{array}$ & -2.00 & 2.91E-03 \\
\hline htrlfb & $\begin{array}{l}\text { ens|5-hydroxytryptamine (serotonin) } \\
\text { receptor 1Fb [Source:ZFIN;Acc:ZDB- } \\
\text { GENE-090312-140] } \\
\text { [ENSDART00000075626] }\end{array}$ & -2.32 & $2.18 \mathrm{E}-03$ \\
\hline igf $2 r$ & $\begin{array}{l}\text { ref|Danio rerio insulin-like growth factor } \\
2 \text { receptor (igf2r), mRNA } \\
\text { [NM_001039627] }\end{array}$ & -2.38 & $1.13 \mathrm{E}-03$ \\
\hline
\end{tabular}




\section{Table S3.}

List of genes differentially expressed upon $24 \mathrm{~h}$ infection of zebrafish larvae (2 days post fertilization) with PA14-WT.

\begin{tabular}{|c|c|c|c|}
\hline Sequence Name(s) & Sequence Description & $\begin{array}{c}\log _{2} \mathbf{F C} \\
\text { (PA14- } \\
\text { WT vs } \\
\text { Control) }\end{array}$ & p-Value \\
\hline hbae 5 & $\begin{array}{l}\text { ref|Danio rerio hemoglobin, alpha } \\
\text { embryonic } 5 \text { (hbae5), mRNA } \\
\text { [NM_001326701] }\end{array}$ & 2.78 & $3.70 \mathrm{E}-06$ \\
\hline cyp1a & $\begin{array}{l}\text { ref|Danio rerio cytochrome P450, family } \\
\text { 1, subfamily A (cyp1a), mRNA } \\
\text { [NM_131879] }\end{array}$ & 2.55 & 2.63E-14 \\
\hline hbae 5 & $\begin{array}{l}\text { ref|Danio rerio hemoglobin, alpha } \\
\text { embryonic } 5 \text { (hbae5), mRNA } \\
\text { [NM_001326701] }\end{array}$ & 2.53 & $1.02 \mathrm{E}-05$ \\
\hline si:dkey-247k7.2 & $\begin{array}{l}\text { ens|si:dkey-247k7.2 } \\
\text { [Source:ZFIN;Acc:ZDB-GENE-031118- } \\
\text { 45] [ENSDART00000158821] }\end{array}$ & 2.25 & $1.21 \mathrm{E}-07$ \\
\hline si:ch73-329n5.6 & $\begin{array}{l}\text { ens|si:ch73-329n5.6 [Source:NCBI } \\
\text { gene;Acc:101883339] } \\
\text { [ENSDART00000193110] }\end{array}$ & 2.10 & 4.93E-08 \\
\hline galnt18a & $\begin{array}{l}\text { ref|Danio rerio UDP-N-acetyl-alpha-D- } \\
\text { galactosamine:polypeptide N- } \\
\text { acetylgalactosaminyltransferase 18a } \\
\text { (galnt18a), mRNA [NM_001130648] }\end{array}$ & 1.87 & $1.79 \mathrm{E}-03$ \\
\hline zgc:153932 & $\begin{array}{l}\text { ref|Danio rerio zgc:153932 (zgc:153932), } \\
\text { mRNA [NM_001083007] }\end{array}$ & 1.81 & $1.11 \mathrm{E}-05$ \\
\hline $\begin{array}{l}\text { ENSDART0000015295 } \\
0\end{array}$ & $\begin{array}{l}\text { gb|PREDICTED: Danio rerio } \\
\text { hypothetical protein LOC100005636 } \\
\text { (LOC100005636), mRNA } \\
\text { [XM_001922840] }\end{array}$ & 1.76 & $5.38 \mathrm{E}-05$ \\
\hline zgc:174917 & $\begin{array}{l}\text { ref|Danio rerio zgc:174917 (zgc:174917), } \\
\text { mRNA [NM_001105590] }\end{array}$ & 1.75 & $5.78 \mathrm{E}-06$ \\
\hline hbbe3 & Unknown & 1.75 & $2.58 \mathrm{E}-03$ \\
\hline irg1l & $\begin{array}{l}\text { ref|Danio rerio immunoresponsive gene 1, } \\
\text { like (irg11), mRNA [NM_001077607] }\end{array}$ & 1.68 & $1.14 \mathrm{E}-04$ \\
\hline XM_001344137 & $\begin{array}{l}\text { gb|PREDICTED: Danio rerio } \\
\text { hypothetical protein LOC100005016 } \\
\text { (LOC100005016), mRNA } \\
\text { [XM_001344137] }\end{array}$ & 1.59 & $9.98 \mathrm{E}-04$ \\
\hline zgc:153932 & $\begin{array}{l}\text { ref|Danio rerio zgc:153932 (zgc:153932), } \\
\text { mRNA [NM_001083007] }\end{array}$ & 1.55 & $8.31 \mathrm{E}-05$ \\
\hline
\end{tabular}


ens|si:ch211-207n23.2

[Source:ZFIN;Acc:ZDB-GENE-131121-

\begin{tabular}{|c|c|c|c|}
\hline si:ch211-207n23.2 & 310] [ENSDART00000155153] & 1.52 & $1.46 \mathrm{E}-04$ \\
\hline hbbe3 & $\begin{array}{l}\text { ref|Danio rerio hemoglobin beta } \\
\text { embryonic-3 (hbbe3), mRNA } \\
{[\mathrm{NM} \text { [001015058] }}\end{array}$ & 1.52 & 4.92E-03 \\
\hline TC440008 & $\begin{array}{l}\text { ref|PREDICTED: Danio rerio } \\
\text { uncharacterized LOC568930 } \\
\text { (LOC568930), transcript variant X1, } \\
\text { mRNA [XM_017358590] }\end{array}$ & 1.50 & 4.76E-05 \\
\hline zgc:172053 & $\begin{array}{l}\text { ref|Danio rerio zgc: } 172053(\mathrm{zgc:}: 172053) \text {, } \\
\text { mRNA [NM_001111242] }\end{array}$ & 1.48 & $6.36 \mathrm{E}-05$ \\
\hline si:dkey-9c18.3 & $\begin{array}{l}\text { ens|si:dkey-9c18.3 } \\
\text { [Source:ZFIN;Acc:ZDB-GENE-121214- } \\
\text { 321] [ENSDART00000152356] }\end{array}$ & 1.47 & 4.94E-02 \\
\hline rhcga & $\begin{array}{l}\text { ref|Danio rerio Rh family, C glycoprotein } \\
\text { a (rhcga), mRNA [NM_001089577] }\end{array}$ & 1.47 & $2.62 \mathrm{E}-02$ \\
\hline si:ch211-153b23.3 & $\begin{array}{l}\text { ens|si:ch211-153b23.3 } \\
\text { [Source:ZFIN;Acc:ZDB-GENE-141216- } \\
\text { 408] [ENSDART00000165275] }\end{array}$ & 1.45 & 6.69E-04 \\
\hline ponzr3 & $\begin{array}{l}\text { ref|Danio rerio plac8 onzin related protein } \\
3 \text { (ponzr3), mRNA [NM_001327984] }\end{array}$ & 1.44 & $1.59 \mathrm{E}-03$ \\
\hline
\end{tabular}

gb|PREDICTED: Danio rerio

hypothetical protein LOC100005016

(LOC100005016), mRNA

\begin{tabular}{|c|c|c|c|}
\hline XM_001344137 & [XM_001344137] & 1.43 & $8.36 \mathrm{E}-03$ \\
\hline zgc:172053 & $\begin{array}{l}\text { ref|Danio rerio zgc: } 172053(\mathrm{zgc}: 172053) \text {, } \\
\text { mRNA [NM_001111242] }\end{array}$ & 1.39 & $9.96 \mathrm{E}-05$ \\
\hline ponzr4 & $\begin{array}{l}\text { ref|Danio rerio plac8 onzin related protein } \\
4 \text { (ponzr4), mRNA [NM_001327980] }\end{array}$ & 1.37 & $1.05 \mathrm{E}-03$ \\
\hline$A \_15 \_P 764266$ & Unknown & 1.35 & $1.93 \mathrm{E}-05$ \\
\hline TC377006 & $\begin{array}{l}\text { tc|Rep: LOC571499 protein - Danio rerio } \\
\text { (Zebrafish) (Brachydanio rerio), partial } \\
(49 \%)[\text { TC377006] }\end{array}$ & 1.31 & $3.56 \mathrm{E}-04$ \\
\hline cypla & $\begin{array}{l}\text { ref|Danio rerio cytochrome P450, family } \\
\text { 1, subfamily A (cyp1a), mRNA } \\
\text { [NM_131879] }\end{array}$ & 1.29 & 2.23E-07 \\
\hline EH452891 & $\begin{array}{l}\text { gb|FDR103-P00059-DEPE-F_J01 } \\
\text { FDR103 Danio rerio cDNA clone } \\
\text { FDR103-P00059-BR_J01 5', mRNA } \\
\text { sequence [EH452891] }\end{array}$ & 1.29 & $5.44 \mathrm{E}-04$ \\
\hline zgc:111983 & $\begin{array}{l}\text { ref|Danio rerio zgc:111983 (zgc:111983), } \\
\text { mRNA [NM_001017803] }\end{array}$ & 1.27 & $1.60 \mathrm{E}-05$ \\
\hline ahrra & $\begin{array}{l}\text { ref|Danio rerio aryl-hydrocarbon receptor } \\
\text { repressor a (ahrra), mRNA } \\
\text { [NM_001035265] }\end{array}$ & 1.22 & 3.79E-09 \\
\hline
\end{tabular}


ref|Danio rerio cathepsin L.1 (ctsl.1),

\begin{tabular}{|c|c|c|c|}
\hline ctsl.1 & mRNA [NM_001002368] & 1.20 & $9.37 \mathrm{E}-04$ \\
\hline$A W 174830$ & $\begin{array}{l}\text { gb|fe06b07.y1 Zebrafish WashU MPIMG } \\
\text { EST Danio rerio cDNA clone } \\
\text { IMAGE:3738037 5' similar to } \\
\text { TR:O88486 O88486 CYTOPLASMIC } \\
\text { DYNEIN INTERMEDIATE CHAIN 1B. } \\
\text { [1] ; contains element PTR5 repetitive } \\
\text { element ;, mRNA sequence [AW174830] }\end{array}$ & 1.18 & $3.75 \mathrm{E}-03$ \\
\hline ponzr4 & $\begin{array}{l}\text { ref|Danio rerio plac8 onzin related protein } \\
4 \text { (ponzr4), mRNA [NM_001327980] }\end{array}$ & 1.17 & $1.75 \mathrm{E}-03$ \\
\hline TC378867 & $\begin{array}{l}\text { ref|PREDICTED: Danio rerio sushi, } \\
\text { nidogen and EGF-like domain-containing } \\
\text { protein } 1 \text { (LOC108179106), mRNA } \\
\text { [XM_001341787] }\end{array}$ & 1.14 & $5.89 \mathrm{E}-04$ \\
\hline$L O C 100005948$ & $\begin{array}{l}\text { ref|PREDICTED: Danio rerio } \\
\text { uncharacterized LOC100005948 } \\
\text { (LOC100005948), mRNA } \\
\text { [XM_001344808] }\end{array}$ & 1.14 & $2.87 \mathrm{E}-03$ \\
\hline ccl20a.3 & $\begin{array}{l}\text { ref|Danio rerio chemokine (C-C motif) } \\
\text { ligand 20a, duplicate } 3 \text { (ccl20a.3), mRNA } \\
\text { [NM_001136254] }\end{array}$ & 1.10 & $1.18 \mathrm{E}-03$ \\
\hline si:ch211-153b23.3 & $\begin{array}{l}\text { ens|si:ch211-153b23.3 } \\
\text { [Source:ZFIN;Acc:ZDB-GENE-141216- } \\
\text { 408] [ENSDART00000165275] }\end{array}$ & 1.09 & $2.02 \mathrm{E}-03$ \\
\hline$z g c: 111983$ & $\begin{array}{l}\text { ref|Danio rerio zgc:111983 (zgc:111983), } \\
\text { mRNA [NM_001017803] }\end{array}$ & 1.09 & $1.76 \mathrm{E}-04$ \\
\hline ctsl.1 & $\begin{array}{l}\text { ref|Danio rerio cathepsin L.1 (ctsl.1), } \\
\text { mRNA [NM_001002368] }\end{array}$ & 1.08 & $1.24 \mathrm{E}-03$ \\
\hline NP13322337 & $\begin{array}{l}\text { tc|GB|XM_001344530.2|XP_001344566. } \\
2 \text { similar to Uromodulin precursor } \\
\text { (Tamm-Horsfall urinary glycoprotein) } \\
\text { (THP) [NP13322337] }\end{array}$ & 1.03 & $1.06 \mathrm{E}-04$ \\
\hline mpeg1.2 & $\begin{array}{l}\text { ref|Danio rerio macrophage expressed } 1 \text {, } \\
\text { tandem duplicate } 2 \text { (mpeg1.2), mRNA } \\
{[\text { NM_001020586] }}\end{array}$ & 1.02 & $5.94 \mathrm{E}-04$ \\
\hline alas2 & $\begin{array}{l}\text { ref|Danio rerio aminolevulinate, delta-, } \\
\text { synthase } 2 \text { (alas2), mRNA [NM_131682] }\end{array}$ & 1.01 & $2.01 \mathrm{E}-02$ \\
\hline cyp $26 a 1$ & $\begin{array}{l}\text { ref|Danio rerio cytochrome P450, family } \\
\text { 26, subfamily A, polypeptide } 1 \\
\text { (cyp26a1), mRNA [NM_131146] }\end{array}$ & 1.01 & $2.00 \mathrm{E}-02$ \\
\hline irg1l & $\begin{array}{l}\text { ref|Danio rerio immunoresponsive gene 1, } \\
\text { like (irg11), mRNA [NM_001077607] }\end{array}$ & 1.01 & $4.45 \mathrm{E}-04$ \\
\hline $\operatorname{eg} \ln 3$ & $\begin{array}{l}\text { ref|Danio rerio egl-9 family hypoxia- } \\
\text { inducible factor } 3(\text { egln } 3), \text { mRNA } \\
\text { [NM_213310] }\end{array}$ & 1.00 & $1.53 \mathrm{E}-03$ \\
\hline
\end{tabular}


ens|cytochrome c oxidase subunit 4I1, like [Source:ZFIN;Acc:ZDB-GENE-

\begin{tabular}{|c|c|c|c|}
\hline $\operatorname{cox} 4 i 11$ & 130814-2] [ENSDART00000105691] & 1.00 & $1.50 \mathrm{E}-05$ \\
\hline zgc:111983 & $\begin{array}{l}\text { ref|Danio rerio zgc:111983 (zgc:111983), } \\
\text { mRNA [NM_001017803] }\end{array}$ & 0.98 & $1.57 \mathrm{E}-03$ \\
\hline hsp70.1 & $\begin{array}{l}\text { ref|Danio rerio heat shock cognate } 70-\mathrm{kd} \\
\text { protein, tandem duplicate } 1 \text { (hsp70.1), } \\
\text { mRNA [NM_001362359] }\end{array}$ & 0.95 & $3.86 \mathrm{E}-02$ \\
\hline tbx16l & $\begin{array}{l}\text { ref|Danio rerio T-box 16, like (tbx161), } \\
\text { mRNA [NM_131052] }\end{array}$ & 0.94 & 2.53E-04 \\
\hline prss60.2 & Unknown & 0.94 & $1.73 \mathrm{E}-05$ \\
\hline A_15_P671586 & Unknown & 0.91 & $1.73 \mathrm{E}-02$ \\
\hline sult5a1 & $\begin{array}{l}\text { ref|Danio rerio sulfotransferase family } \\
\text { 5A, member } 1 \text { (sult5a1), mRNA } \\
{\left[\mathrm{NM} \_001076656\right]}\end{array}$ & 0.91 & $1.28 \mathrm{E}-02$ \\
\hline si:dkeyp-34c12.1 & $\begin{array}{l}\text { ref|Danio rerio si:dkeyp-34c12.1 } \\
\text { (si:dkeyp-34c12.1), transcript variant } 2 \text {, } \\
\text { mRNA [NM_001104944] }\end{array}$ & 0.90 & $1.81 \mathrm{E}-02$ \\
\hline prss60.2 & $\begin{array}{l}\text { ref|Danio rerio serine protease } 60.2 \\
\text { (prss60.2), mRNA [NM_001105601] }\end{array}$ & 0.90 & $5.42 \mathrm{E}-04$ \\
\hline zgc:158404 & $\begin{array}{l}\text { ref|Danio rerio zgc:158404 (zgc:158404), } \\
\text { mRNA [NM_001080565] }\end{array}$ & 0.89 & $1.50 \mathrm{E}-03$ \\
\hline
\end{tabular}

EST Danio rerio cDNA clone

IMAGE:3719426 3', mRNA sequence

\begin{tabular}{|c|c|c|c|}
\hline$w u: f b 93 c 02$ & [AI584407] & 0.89 & $2.96 \mathrm{E}-03$ \\
\hline cyp26a1 & $\begin{array}{l}\text { ref|Danio rerio cytochrome P450, family } \\
\text { 26, subfamily A, polypeptide } 1 \\
\text { (cyp26a1), mRNA [NM_131146] }\end{array}$ & 0.89 & 4.36E-02 \\
\hline rfesd & $\begin{array}{l}\text { ref|Danio rerio Rieske }(\mathrm{Fe}-\mathrm{S}) \text { domain } \\
\text { containing }(\text { rfesd), mRNA } \\
\text { [NM_001017740] }\end{array}$ & 0.89 & 9.98E-03 \\
\hline eevs & $\begin{array}{l}\text { ens|2-epi-5-epi-valiolone synthase } \\
\text { [Source:ZFIN;Acc:ZDB-GENE-131121- } \\
\text { 365] [ENSDART00000122423] }\end{array}$ & 0.88 & 8.48E-05 \\
\hline LOC100535095 & $\begin{array}{l}\text { ref|Danio rerio uncharacterized } \\
\text { LOC100535095 (LOC100535095), long } \\
\text { non-coding RNA [NR_138558] }\end{array}$ & 0.87 & $5.00 \mathrm{E}-03$ \\
\hline tmem176l.2 & $\begin{array}{l}\text { ens|transmembrane protein } 1761.2 \\
\text { [Source:ZFIN;Acc:ZDB-GENE-080829- } \\
\text { 12] [ENSDART00000132926] }\end{array}$ & 0.87 & $5.31 \mathrm{E}-03$ \\
\hline$m f s d 4 a b$ & $\begin{array}{l}\text { ref|Danio rerio major facilitator } \\
\text { superfamily domain containing } 4 \mathrm{Ab} \\
(\mathrm{mfsd} 4 \mathrm{ab}), \text { mRNA [NM_001114416] }\end{array}$ & 0.85 & $6.04 \mathrm{E}-04$ \\
\hline foxqla & $\begin{array}{l}\text { ref|Danio rerio forkhead box Q1a } \\
\text { (foxq1a), mRNA [NM_001243344] }\end{array}$ & 0.85 & $3.42 \mathrm{E}-04$ \\
\hline
\end{tabular}




\begin{tabular}{|c|c|c|c|}
\hline lgals 111 & $\begin{array}{l}\text { tc|GB|BC164225.1|AAI64225.1 lgals111 } \\
\text { protein [NP13225910] }\end{array}$ & 0.85 & $1.37 \mathrm{E}-02$ \\
\hline cyp $1 a$ & $\begin{array}{l}\text { ref|Danio rerio cytochrome P450, family } \\
\text { 1, subfamily A (cyp1a), mRNA } \\
\text { [NM_131879] }\end{array}$ & 0.83 & $6.93 \mathrm{E}-05$ \\
\hline zgc:172053 & $\begin{array}{l}\text { ref|Danio rerio zgc: } 172053 \text { (zgc:172053), } \\
\text { mRNA [NM_001111242] }\end{array}$ & 0.79 & $4.29 \mathrm{E}-03$ \\
\hline lgals3bpb & $\begin{array}{l}\text { ref|Danio rerio lectin, galactoside- } \\
\text { binding, soluble, } 3 \text { binding protein b } \\
\text { (lgals3bpb), mRNA [NM_212873] }\end{array}$ & 0.79 & $3.13 \mathrm{E}-03$ \\
\hline erola & $\begin{array}{l}\text { ref|Danio rerio endoplasmic reticulum } \\
\text { oxidoreductase alpha (ero1a), mRNA } \\
\text { [NM_200350] }\end{array}$ & 0.78 & $1.73 \mathrm{E}-06$ \\
\hline TC388923 & $\begin{array}{l}\text { ref|PREDICTED: Danio rerio } \\
\text { uncharacterized LOC108179107 } \\
\text { (LOC108179107), transcript variant X1, } \\
\text { mRNA [XM_009306955] }\end{array}$ & 0.77 & $5.86 \mathrm{E}-04$ \\
\hline $\begin{array}{l}\text { ENSDART0000014674 } \\
8\end{array}$ & $\begin{array}{l}\text { ens|si:dkey-21e2.3 } \\
\text { [Source:ZFIN;Acc:ZDB-GENE-050208- } \\
\text { 618] [ENSDART00000146748] }\end{array}$ & 0.77 & $6.43 \mathrm{E}-03$ \\
\hline p4halb & $\begin{array}{l}\text { ref|Danio rerio prolyl 4-hydroxylase, } \\
\text { alpha polypeptide I b (p4ha1b), mRNA } \\
\text { [NM_214691] }\end{array}$ & 0.77 & $1.25 \mathrm{E}-03$ \\
\hline slc $7 a 3 b$ & $\begin{array}{l}\text { ens|solute carrier family } 7 \text { (cationic amino } \\
\text { acid transporter, y+ system), member 3b } \\
\text { [Source:ZFIN;Acc:ZDB-GENE-120813- } \\
\text { 6] [ENSDART00000087918] }\end{array}$ & 0.77 & $3.91 \mathrm{E}-03$ \\
\hline mmp13a & $\begin{array}{l}\text { ref|Danio rerio matrix metallopeptidase } \\
\text { 13a (mmp13a), mRNA [NM_001290479] }\end{array}$ & 0.76 & $3.20 \mathrm{E}-02$ \\
\hline pck1 & $\begin{array}{l}\text { ref|Danio rerio phosphoenolpyruvate } \\
\text { carboxykinase } 1 \text { (soluble) (pck1), mRNA } \\
\text { [NM_214751] }\end{array}$ & 0.76 & 4.72E-03 \\
\hline cyp26c1 & $\begin{array}{l}\text { ref|Danio rerio cytochrome P450, family } \\
\text { 26, subfamily C, polypeptide } 1 \text { (cyp26c1), } \\
\text { mRNA [NM_001029951] }\end{array}$ & 0.75 & $2.03 \mathrm{E}-03$ \\
\hline zgc:162608 & $\begin{array}{l}\text { ref|Danio rerio zgc:162608 (zgc:162608), } \\
\text { mRNA [NM_001089487] }\end{array}$ & 0.75 & $7.22 \mathrm{E}-03$ \\
\hline$z g c: 162608$ & $\begin{array}{l}\text { ref|Danio rerio zgc:162608 (zgc:162608), } \\
\text { mRNA [NM_001089487] }\end{array}$ & 0.75 & $5.94 \mathrm{E}-03$ \\
\hline LOC108179106 & $\begin{array}{l}\text { ens|si:ch73-329n5.2 } \\
\text { [Source:ZFIN;Acc:ZDB-GENE-131121- } \\
\text { 66] [ENSDART00000180059] }\end{array}$ & 0.75 & $1.36 \mathrm{E}-05$ \\
\hline LOC571499 & $\begin{array}{l}\text { ens|si:ch73-329n5.1 } \\
\text { [Source:ZFIN;Acc:ZDB-GENE-131121- } \\
\text { 475] [ENSDART00000166273] }\end{array}$ & 0.74 & $2.58 \mathrm{E}-05$ \\
\hline
\end{tabular}


ref|Danio rerio myosin, light chain 9b, regulatory (myl9b), mRNA

\begin{tabular}{|c|c|c|c|}
\hline myl9b & [NM_213212] & 0.73 & $2.51 \mathrm{E}-02$ \\
\hline p4ha1b & Unknown & 0.72 & 3.98E-04 \\
\hline fundc2 & $\begin{array}{l}\text { ref|Danio rerio fun14 domain containing } 2 \\
\text { (fundc2), mRNA [NM_001005954] }\end{array}$ & 0.72 & $3.30 \mathrm{E}-03$ \\
\hline elf3 & $\begin{array}{l}\text { ens|E74-like factor } 3 \text { (ets domain } \\
\text { transcription factor, epithelial-specific ) } \\
\text { [Source:ZFIN;Acc:ZDB-GENE-030131- } \\
\text { 8760] [ENSDART00000149460] }\end{array}$ & 0.72 & $1.46 \mathrm{E}-03$ \\
\hline TC379404 & $\begin{array}{l}\text { tc|Rep: Secretogranin III - Danio rerio } \\
\text { (Zebrafish) (Brachydanio rerio), partial } \\
(92 \%)[\text { TC379404] }\end{array}$ & 0.71 & 2.29E-03 \\
\hline cxcl19 & $\begin{array}{l}\text { ref|Danio rerio chemokine }(\mathrm{C}-\mathrm{X}-\mathrm{C} \text { motif }) \\
\text { ligand } 19(\mathrm{cxcl} 19), \text { mRNA } \\
{\left[\mathrm{NM} \_001113651\right]}\end{array}$ & 0.71 & $2.21 \mathrm{E}-03$ \\
\hline hspa8 & $\begin{array}{l}\text { ref|Danio rerio heat shock protein } 8 \\
(\mathrm{hspa} 8), \text { mRNA [NM_001110403] }\end{array}$ & 0.70 & $3.40 \mathrm{E}-04$ \\
\hline staul & $\begin{array}{l}\text { ref|Danio rerio staufen double-stranded } \\
\text { RNA binding protein } 1 \text { (stau1), mRNA } \\
\text { [NM_205561] }\end{array}$ & 0.68 & 9.88E-04 \\
\hline zgc:111983 & Unknown & 0.68 & $3.78 \mathrm{E}-02$ \\
\hline sult6b1 & $\begin{array}{l}\text { ref|Danio rerio sulfotransferase family, } \\
\text { cytosolic, } 6 \mathrm{~b}, \text { member } 1 \text { (sult6b1), mRNA } \\
{\left[\mathrm{NM} \_214686\right]}\end{array}$ & 0.68 & 2.69E-05 \\
\hline bcas 2 & $\begin{array}{l}\text { ref|Danio rerio BCAS2, pre-mRNA } \\
\text { processing factor (bcas2), mRNA } \\
{[\mathrm{NM}[001007774]}\end{array}$ & 0.68 & $1.74 \mathrm{E}-02$ \\
\hline dnase1l1l & $\begin{array}{l}\text { ref|Danio rerio deoxyribonuclease I-like } \\
\text { 1-like (dnase1l11), mRNA } \\
\text { [NM_001002403] }\end{array}$ & 0.67 & 3.04E-02 \\
\hline eif3ea & $\begin{array}{l}\text { ref|Danio rerio eukaryotic translation } \\
\text { initiation factor 3, subunit E, a (eif3ea), } \\
\text { mRNA [NM_200839] }\end{array}$ & 0.67 & 9.65E-06 \\
\hline & $\begin{array}{l}\text { ref|PREDICTED: Danio rerio } \\
\text { uncharacterized LOC100536887 } \\
\text { (LOC100536887), mRNA }\end{array}$ & & \\
\hline TC377034 & [XM_003201704] & 0.67 & $1.87 \mathrm{E}-02$ \\
\hline stc1l & $\begin{array}{l}\text { ref|Danio rerio stanniocalcin } 1, \text { like } \\
(\mathrm{stc} 11), \text { mRNA [NM_200539] }\end{array}$ & 0.67 & $8.55 \mathrm{E}-03$ \\
\hline & $\begin{array}{l}\text { ref|Danio rerio cytochrome } \mathrm{P} 450 \text {, family } \\
1 \text {, subfamily } \mathrm{B} \text {, polypeptide } 1 \text { (cyp } 1 \mathrm{~b} 1) \text {, } \\
\text { transcript variant } 3, \text { mRNA }\end{array}$ & & \\
\hline cyp1b1 & [NM_001145708] & 0.67 & $2.15 \mathrm{E}-03$ \\
\hline
\end{tabular}


tc|GB|XM_001343781.2|XP_001343817.

ENSDART0000016202 2 similar to protease, serine 27

7

[NP13317523]

0.67

6.78E-03

ref|Danio rerio 6-phosphofructo-2-

kinase/fructose-2,6-biphosphatase 3

$p f k f b 3$

(pfkfb3), mRNA [NM_213397]

0.67

2.57E-03

tc|Rep: Copia-type polyprotein -

Arabidopsis thaliana (Mouse-ear cress),

TC454255

partial (10\%) [TC454255]

0.67

$3.26 \mathrm{E}-02$

gb|FDR103-P00060-DEPE-F_O04

FDR103 Danio rerio cDNA clone

FDR103-P00060-BR_O04 5', mRNA

BC054571

sequence [EH453373]

0.66

$1.66 \mathrm{E}-04$

ref|Danio rerio cytochrome P450, family

cyp 1 c2

1 , subfamily C, polypeptide 2 (cyp1c2),

mRNA [NM_001114849]

0.65

1.04E-02

ref|Danio rerio leucine rich repeat

neuronal 1 (lrrn1), mRNA

lrrn1

[NM_001130694]

0.65

$1.48 \mathrm{E}-05$

gb|CT648970 ZF_mu Danio rerio cDNA

clone ZF_mu_101c10 5', mRNA

CT648970

sequence [CT648970]

0.65

1.87E-02

ref|Danio rerio sorting nexin 4 (snx4),

$\operatorname{snx} 4$

mRNA [NM_001014346]

0.65

3.47E-04

ref|Danio rerio family with sequence

similarity 114, member A1 (fam114a1),

fam114a1

mRNA [NM_001089478]

0.65

3.38E-02

tc|Rep: Protogenin A precursor - Danio

rerio (Zebrafish) (Brachydanio rerio),

$\begin{array}{ll}\text { prtga } & \text { complete [TC366174] } \\ & \text { ref|Danio rerio zgc:163057 (zgc:163057) }\end{array}$

zgc:163057

mRNA [NM_001082834]

0.65

3.24E-04

0.65

1.44E-02

ref|Danio rerio NADPH oxidase organizer

noxola

1a (noxo1a), mRNA [NM_001077584]

0.65

3.65E-04

ref|Danio rerio egl-9 family hypoxia-

inducible factor 3 (egln3), mRNA

egln3

[NM_213310]

0.65

$1.78 \mathrm{E}-02$

ref|Danio rerio fucosyltransferase 9d

fut9d

(fut9d), mRNA [NM_001077246]

0.63

4.15E-03

ref|Danio rerio cytochrome P450, family

1 , subfamily C, polypeptide 1 (cyp1c1),

cyp1c1

mRNA [NM_001020610]

0.63

1.14E-02

ref|Danio rerio SERPINE1 mRNA

binding protein 1a (serbp1a), mRNA

serbp1a

[NM_214714]

0.63

1.33E-05 
ref|Danio rerio purine nucleoside

phosphorylase $4 \mathrm{~b}$ (pnp4b), mRNA

\begin{tabular}{|c|c|c|c|}
\hline pnp4b & [NM_205643] & 0.63 & $3.32 \mathrm{E}-02$ \\
\hline pkhd1l1 & $\begin{array}{l}\text { ref|Danio rerio polycystic kidney and } \\
\text { hepatic disease } 1 \text { (autosomal recessive)- } \\
\text { like } 1 \text { (pkhd111), mRNA } \\
\text { [NM_001318128] }\end{array}$ & 0.62 & 7.17E-04 \\
\hline slc $2 a 15 b$ & $\begin{array}{l}\text { ref|Danio rerio solute carrier family } 2 \\
\text { (facilitated glucose transporter), member } \\
\text { 15b (slc2a15b), mRNA [NM_001020494] }\end{array}$ & 0.62 & 2.77E-02 \\
\hline $\operatorname{chd} 4 b$ & $\begin{array}{l}\text { ens|chromodomain helicase DNA binding } \\
\text { protein 4a [Source:ZFIN;Acc:ZDB- } \\
\text { GENE-041111-187] } \\
\text { [ENSDART00000005453] }\end{array}$ & 0.62 & $1.33 \mathrm{E}-02$ \\
\hline emg1 & $\begin{array}{l}\text { tc|Rep: LOC553478 protein - Danio rerio } \\
\text { (Zebrafish) (Brachydanio rerio), complete } \\
\text { [TC376782] }\end{array}$ & 0.62 & $1.69 \mathrm{E}-02$ \\
\hline zgc:158404 & $\begin{array}{l}\text { ref|Danio rerio zgc:158404 (zgc:158404), } \\
\text { mRNA [NM_001080565] }\end{array}$ & 0.62 & $1.52 \mathrm{E}-02$ \\
\hline tbx $16 l$ & $\begin{array}{l}\text { ref|Danio rerio T-box 16, like (tbx161), } \\
\text { mRNA [NM_131052] }\end{array}$ & 0.62 & $4.19 \mathrm{E}-03$ \\
\hline$t c n b b$ & $\begin{array}{l}\text { ref|Danio rerio si:ch211-117m20.5 } \\
\text { (si:ch211-117m20.5), mRNA } \\
\text { [NM_001252649] }\end{array}$ & 0.61 & $2.72 \mathrm{E}-04$ \\
\hline serpinh1a & $\begin{array}{l}\text { ref|Danio rerio serpin peptidase inhibitor, } \\
\text { clade } \mathrm{H} \text { (heat shock protein 47), member } \\
\text { 1a (serpinh1a), mRNA [NM_001110374] }\end{array}$ & 0.61 & $3.12 \mathrm{E}-04$ \\
\hline$v c a n b$ & $\begin{array}{l}\text { ref|Danio rerio versican b (vcanb), mRNA } \\
\text { [NM_214688] }\end{array}$ & 0.60 & $2.34 \mathrm{E}-04$ \\
\hline pdia3 & $\begin{array}{l}\text { ref|Danio rerio protein disulfide } \\
\text { isomerase family A, member } 3 \text { (pdia3), } \\
\text { mRNA [NM_001199737] }\end{array}$ & 0.60 & $2.80 \mathrm{E}-05$ \\
\hline g6рса.1 & $\begin{array}{l}\text { ref|Danio rerio glucose-6-phosphatase a, } \\
\text { catalytic subunit, tandem duplicate } 1 \\
\text { (g6pca.1), transcript variant 1, mRNA } \\
\text { [NM_001003512] }\end{array}$ & 0.60 & 3.63E-02 \\
\hline gstm.1 & $\begin{array}{l}\text { ref|Danio rerio glutathione S-transferase } \\
\text { mu, tandem duplicate } 1 \text { (gstm.1), mRNA } \\
{[\text { NM_212676] }}\end{array}$ & -0.60 & $1.54 \mathrm{E}-05$ \\
\hline gnat1 & $\begin{array}{l}\text { ref|Danio rerio guanine nucleotide } \\
\text { binding protein (G protein), alpha } \\
\text { transducing activity polypeptide } 1 \\
\text { (gnat1), mRNA [NM_131868] }\end{array}$ & -0.60 & $1.94 \mathrm{E}-02$ \\
\hline cyp $2 k 16$ & $\begin{array}{l}\text { ref|Danio rerio cytochrome P450, family } \\
\text { 2, subfamily K, polypeptide16 (cyp2k16), } \\
\text { mRNA [NM_001005963] }\end{array}$ & -0.61 & $6.28 \mathrm{E}-05$ \\
\hline
\end{tabular}


ref|Danio rerio creatine kinase,

mitochondrial 2a (sarcomeric) (ckmt2a),

transcript variant 1 , mRNA

\begin{tabular}{|c|c|c|c|}
\hline ckmt2a & [NM_001308608] & -0.61 & $3.39 \mathrm{E}-02$ \\
\hline si:dkeyp-110c7.4 & $\begin{array}{l}\text { ens|si:dkeyp-110c7.4 } \\
\text { [Source:ZFIN;Acc:ZDB-GENE-070705- } \\
\text { 532] [ENSDART00000164279] }\end{array}$ & -0.61 & $4.54 \mathrm{E}-07$ \\
\hline si:ch211-195b11.3 & $\begin{array}{l}\text { ref|Danio rerio si:ch211-195b11.3 } \\
\text { (si:ch211-195b11.3), mRNA } \\
\text { [NM_001291900] }\end{array}$ & -0.61 & $3.82 \mathrm{E}-05$ \\
\hline$k r t 15$ & $\begin{array}{l}\text { ref|Danio rerio keratin } 15 \text { (krt15), mRNA } \\
\text { [NM_213523] }\end{array}$ & -0.61 & $3.78 \mathrm{E}-04$ \\
\hline itih3a & $\begin{array}{l}\text { ref|Danio rerio inter-alpha-trypsin } \\
\text { inhibitor heavy chain 3a (itih3a), mRNA } \\
\text { [NM_001020588] }\end{array}$ & -0.61 & $2.73 \mathrm{E}-02$ \\
\hline ucmab & $\begin{array}{l}\text { ref|Danio rerio upper zone of growth plate } \\
\text { and cartilage matrix associated b (ucmab), } \\
\text { mRNA [NM_212934] }\end{array}$ & -0.61 & $1.78 \mathrm{E}-03$ \\
\hline matn $3 a$ & $\begin{array}{l}\text { ref|Danio rerio matrilin 3a (matn3a), } \\
\text { transcript variant } 1, \text { mRNA } \\
{[\text { [NM_001004007] }}\end{array}$ & -0.61 & $7.19 \mathrm{E}-03$ \\
\hline$k r t 15$ & $\begin{array}{l}\text { ref|Danio rerio keratin } 15 \text { (krt15), mRNA } \\
\text { [NM_213523] }\end{array}$ & -0.61 & $5.47 \mathrm{E}-04$ \\
\hline tmem $237 a$ & $\begin{array}{l}\text { ref|Danio rerio transmembrane protein } \\
\text { 237a }(\text { tmem237a), mRNA } \\
\text { [NM_001319136] }\end{array}$ & -0.61 & $4.57 \mathrm{E}-03$ \\
\hline tnni2a.1 & $\begin{array}{l}\text { ref|Danio rerio troponin I type 2a } \\
\text { (skeletal, fast), tandem duplicate } 1 \\
\text { (tnni2a.1), mRNA [NM_001007365] }\end{array}$ & -0.61 & $1.57 \mathrm{E}-02$ \\
\hline$a q p 8 b$ & $\begin{array}{l}\text { ref|Danio rerio aquaporin 8b (aqp8b), } \\
\text { mRNA [NM_001114910] }\end{array}$ & -0.61 & $1.13 \mathrm{E}-03$ \\
\hline cishb & $\begin{array}{l}\text { ref|Danio rerio cytokine inducible SH2- } \\
\text { containing protein b (cishb), mRNA } \\
\text { [NM_001114554] }\end{array}$ & -0.61 & $4.29 \mathrm{E}-03$ \\
\hline ccl34b.1 & $\begin{array}{l}\text { ref|Danio rerio chemokine (C-C motif) } \\
\text { ligand 34b, duplicate } 1 \text { (ccl34b.1), mRNA } \\
\text { [NM_001115054] }\end{array}$ & -0.61 & $1.55 \mathrm{E}-03$ \\
\hline prph2a & $\begin{array}{l}\text { ref|Danio rerio peripherin 2a (retinal } \\
\text { degeneration, slow) (prph2a), mRNA } \\
\text { [NM_131566] }\end{array}$ & -0.62 & $5.42 \mathrm{E}-03$ \\
\hline zgc:112146 & $\begin{array}{l}\text { ref|Danio rerio zgc:112146 (zgc:112146), } \\
\text { mRNA [NM_001017731] }\end{array}$ & -0.62 & $5.50 \mathrm{E}-04$ \\
\hline mgst2 & $\begin{array}{l}\text { ref|Danio rerio microsomal glutathione S- } \\
\text { transferase } 2 \text { (mgst2), mRNA } \\
{[\text { [NM_001045302] }}\end{array}$ & -0.62 & $2.61 \mathrm{E}-03$ \\
\hline
\end{tabular}


ref|Danio rerio jacalin 10 (jac10), mRNA

\begin{tabular}{|c|c|c|c|}
\hline jac10 & [NM_001110036] & -0.62 & $1.49 \mathrm{E}-02$ \\
\hline cpb1 & $\begin{array}{l}\text { ref|Danio rerio carboxypeptidase B1 } \\
\text { (tissue) (cpb1), transcript variant 2, } \\
\text { mRNA [NM_001110021] }\end{array}$ & -0.62 & $2.24 \mathrm{E}-04$ \\
\hline klhdc3 & $\begin{array}{l}\text { gb|AGENCOURT_21025036 } \\
\text { NIH_ZGC_8 Danio rerio cDNA clone } \\
\text { IMAGE:7242183 5', mRNA sequence } \\
\text { [CN174295] }\end{array}$ & -0.62 & $9.22 \mathrm{E}-03$ \\
\hline apbb1ip & $\begin{array}{l}\text { ref|Danio rerio amyloid beta (A4) } \\
\text { precursor protein-binding, family B, } \\
\text { member } 1 \text { interacting protein (apbb1ip), } \\
\text { mRNA [NM_200634] }\end{array}$ & -0.62 & $1.28 \mathrm{E}-02$ \\
\hline rbp2a & $\begin{array}{l}\text { ref|Danio rerio retinol binding protein 2a, } \\
\text { cellular (rbp2a), mRNA [NM_153004] }\end{array}$ & -0.63 & 4.27E-02 \\
\hline gucy2d & $\begin{array}{l}\text { ref|Danio rerio guanylate cyclase 2D, } \\
\text { retinal (gucy2d), mRNA [NM_131866] }\end{array}$ & -0.63 & $5.35 \mathrm{E}-03$ \\
\hline$s v 2 b a$ & $\begin{array}{l}\text { ref|Danio rerio synaptic vesicle } \\
\text { glycoprotein 2Ba (sv2ba), mRNA } \\
\text { [NM_001082995] }\end{array}$ & -0.63 & $7.68 \mathrm{E}-03$ \\
\hline$A \quad 15 \quad P 156651$ & Unknown & -0.63 & $1.07 \mathrm{E}-02$ \\
\hline si:ch211-240119.5 & $\begin{array}{l}\text { ref|Danio rerio si:ch211-240119.5 } \\
\text { (si:ch211-240119.5), mRNA } \\
\text { [NM_001030152] }\end{array}$ & -0.63 & $2.66 \mathrm{E}-04$ \\
\hline LOC110437731 & $\begin{array}{l}\text { ens|haptoglobin [Source:ZFIN;Acc:ZDB- } \\
\text { GENE-030131-1259] } \\
\text { [ENSDART00000149010] }\end{array}$ & -0.63 & 9.37E-03 \\
\hline ezra & $\begin{array}{l}\text { ref|Danio rerio ezrin a (ezra), mRNA } \\
\text { [NM_001020490] }\end{array}$ & -0.64 & $2.95 \mathrm{E}-03$ \\
\hline crybgx & $\begin{array}{l}\text { ref|Danio rerio crystallin beta gamma X } \\
\text { (crybgx), mRNA [NM_001033722] }\end{array}$ & -0.64 & 4.17E-02 \\
\hline cnga3a & $\begin{array}{l}\text { ens|cyclic nucleotide gated channel alpha } \\
\text { 3a [Source:ZFIN;Acc:ZDB-GENE- } \\
\text { 090611-2] [ENSDART00000149833] }\end{array}$ & -0.64 & $1.59 \mathrm{E}-03$ \\
\hline gngt2a & Unknown & -0.64 & $9.93 \mathrm{E}-03$ \\
\hline grk7a & $\begin{array}{l}\text { ref|Danio rerio G protein-coupled } \\
\text { receptor kinase 7a (grk7a), mRNA } \\
{[\text { NM_001031841] }}\end{array}$ & -0.65 & $2.11 \mathrm{E}-03$ \\
\hline csnkla1 & $\begin{array}{l}\text { ref|Danio rerio casein kinase 1, alpha } 1 \\
\text { (csnk1a1), mRNA [NM_152951] }\end{array}$ & -0.65 & $7.62 \mathrm{E}-03$ \\
\hline krt96 & $\begin{array}{l}\text { ref|Danio rerio keratin } 96 \text { (krt96), mRNA } \\
\text { [NM_001199952] }\end{array}$ & -0.65 & $2.26 \mathrm{E}-03$ \\
\hline cplx $4 a$ & $\begin{array}{l}\text { ref|Danio rerio complexin 4a (cplx4a), } \\
\text { mRNA [NM_001077300] }\end{array}$ & -0.65 & $1.51 \mathrm{E}-02$ \\
\hline cgref1 & $\begin{array}{l}\text { ens|cell growth regulator with EF-hand } \\
\text { domain } 1 \text { [Source:ZFIN;Acc:ZDB- }\end{array}$ & -0.65 & $2.94 \mathrm{E}-02$ \\
\hline
\end{tabular}


GENE-131121-137]

[ENSDART00000155002]

ref|Danio rerio zgc:113232 (zgc:113232),

transcript variant 2, mRNA

zgc:113232

[NM_001127513]

$-0.65$

$5.21 \mathrm{E}-03$

ref|Danio rerio collagen, type IX, alpha

col9a1b

1b (col9a1b), mRNA [NM_213264]

ens|si:dkey-96g2.1

[Source:ZFIN;Acc:ZDB-GENE-131121-

si:dkey-96g2.1

563] [ENSDART00000155131]

ref|Danio rerio matrilin 3a (matn3a),

transcript variant 1 , mRNA

matn3a

[NM_001004007]

$-0.66$

2.36E-02

ref|Danio rerio zgc:110789 (zgc:110789),

zgc:110789

mRNA [NM_001013335]

$-0.66$

3.98E-02

ref|Danio rerio arrestin 3a, retinal (X-

arrestin) (arr3a), mRNA

arr $3 a$

[NM_001002405]

$-0.66$

4.09E-02

ref|Danio rerio sulfotransferase family 2,

cytosolic sulfotransferase 2 (sult2st2),

sult2st2

mRNA [NM_001078169] $-0.66$

1.19E-02

ref|Danio rerio si:dkey-266f7.4 (si:dkey-

si:dkey-266f7.4

266f7.4), mRNA [NM_001100018]

ens|cytosolic 5'-nucleotidase 1A

[Source:NCBI gene;Acc:560627]

LOC560627

[ENSDART00000184275]

$-0.66$

4.05E-02

ens|membrane bound O-acyltransferase

domain containing 1

[Source:ZFIN;Acc:ZDB-GENE-041114-

\begin{tabular}{|c|c|c|c|}
\hline mboat1 & 98] [ENSDART00000141860] & -0.66 & $1.08 \mathrm{E}-05$ \\
\hline epd & $\begin{array}{l}\text { ref|Danio rerio ependymin (epd), mRNA } \\
\text { [NM_131005] }\end{array}$ & -0.66 & $1.39 \mathrm{E}-02$ \\
\hline prph $2 a$ & $\begin{array}{l}\text { ref|Danio rerio peripherin } 2 \mathrm{a} \text { (retinal } \\
\text { degeneration, slow) (prph2a), mRNA } \\
{\left[\mathrm{NM} \_131566\right]}\end{array}$ & -0.66 & 8.98E-04 \\
\hline acmsd & $\begin{array}{l}\text { ref|Danio rerio aminocarboxymuconate } \\
\text { semialdehyde decarboxylase (acmsd), } \\
\text { mRNA [NM_001089494] }\end{array}$ & -0.67 & $9.51 \mathrm{E}-03$ \\
\hline $\operatorname{csnk} 2 a 1$ & $\begin{array}{l}\text { ref|Danio rerio casein kinase } 2 \text {, alpha } 1 \\
\text { polypeptide (csnk2a1), mRNA } \\
{\left[\mathrm{NM} \_131252\right]}\end{array}$ & -0.67 & 2.57E-03 \\
\hline$a q p 8 b$ & $\begin{array}{l}\text { ref|Danio rerio aquaporin } 8 \mathrm{~b}(\mathrm{aqp} 8 \mathrm{~b}) \\
\text { mRNA [NM_001114910] }\end{array}$ & -0.67 & $1.58 \mathrm{E}-04$ \\
\hline stoml3b & $\begin{array}{l}\text { ref|Danio rerio stomatin (EPB72)-like 3b } \\
\text { (stoml3b), mRNA [NM_001017825] }\end{array}$ & -0.67 & $1.17 \mathrm{E}-03$ \\
\hline
\end{tabular}


ref|Danio rerio elastase 2 like (ela2l),

\begin{tabular}{|c|c|c|c|}
\hline ela2l & mRNA [NM_199886] & -0.67 & $3.28 \mathrm{E}-02$ \\
\hline zgc:77748 & $\begin{array}{l}\text { ref|Danio rerio zgc:77748 (zgc:77748), } \\
\text { mRNA [NM_200858] }\end{array}$ & -0.67 & $3.23 \mathrm{E}-03$ \\
\hline$z g c: 193726$ & $\begin{array}{l}\text { ref|Danio rerio zgc:193726 (zgc:193726), } \\
\text { mRNA [NM_001135973] }\end{array}$ & -0.68 & $6.61 \mathrm{E}-03$ \\
\hline $\operatorname{erp} 27$ & $\begin{array}{l}\text { tc|Rep: Chromosome undetermined } \\
\text { SCAF12091, whole genome shotgun } \\
\text { sequence - Tetraodon nigroviridis (Green } \\
\text { puffer), partial (71\%) [TC377954] }\end{array}$ & -0.68 & $5.03 \mathrm{E}-03$ \\
\hline crip1 & $\begin{array}{l}\text { ref|Danio rerio cysteine-rich protein } 1 \\
\text { (crip1), transcript variant 2, mRNA } \\
\text { [NM_001166582] }\end{array}$ & -0.68 & $4.15 \mathrm{E}-03$ \\
\hline trpv6 & $\begin{array}{l}\text { ref|Danio rerio transient receptor potential } \\
\text { cation channel, subfamily V, member } 6 \\
\text { (trpv6), mRNA [NM_001001849] }\end{array}$ & -0.68 & $8.87 \mathrm{E}-07$ \\
\hline cpb1 & $\begin{array}{l}\text { ref|Danio rerio carboxypeptidase B1 } \\
\text { (tissue) (cpb1), transcript variant 2, } \\
\text { mRNA [NM_001110021] }\end{array}$ & -0.68 & $2.31 \mathrm{E}-04$ \\
\hline NP13322978 & $\begin{array}{l}\text { tc|GB|XM_001919422.1|XP_001919457. } \\
1 \text { similar to pol polyprotein } \\
\text { [NP13322978] }\end{array}$ & -0.68 & $1.16 \mathrm{E}-03$ \\
\hline A_15_P201336 & Unknown & -0.68 & $3.77 \mathrm{E}-04$ \\
\hline $\operatorname{crygm} 2 f$ & $\begin{array}{l}\text { ref|Danio rerio crystallin, gamma M2f } \\
\text { (crygm2f), mRNA [NM_001110106] }\end{array}$ & -0.69 & $6.07 \mathrm{E}-03$ \\
\hline guklb & $\begin{array}{l}\text { ref|Danio rerio guanylate kinase } 1 \mathrm{~b} \\
\text { (guk1b), mRNA [NM_200724] }\end{array}$ & -0.69 & 7.43E-03 \\
\hline mustn1b & $\begin{array}{l}\text { ref|Danio rerio musculoskeletal, } \\
\text { embryonic nuclear protein 1b (mustn1b), } \\
\text { mRNA [NM_001197053] }\end{array}$ & -0.69 & $3.21 \mathrm{E}-02$ \\
\hline fabp2 & $\begin{array}{l}\text { ref|Danio rerio fatty acid binding protein } \\
2 \text {, intestinal (fabp2), mRNA } \\
\text { [NM_131431] }\end{array}$ & -0.70 & $1.36 \mathrm{E}-03$ \\
\hline si:dkey-188i13.6 & $\begin{array}{l}\text { ref|Danio rerio si:dkey-188i13.6 (si:dkey- } \\
\text { 188i13.6), mRNA [NM_001327855] }\end{array}$ & -0.70 & $2.05 \mathrm{E}-03$ \\
\hline socs1a & $\begin{array}{l}\text { ref|Danio rerio suppressor of cytokine } \\
\text { signaling 1a (socs1a), mRNA } \\
\text { [NM_001003467] }\end{array}$ & -0.70 & $6.27 \mathrm{E}-05$ \\
\hline cish & $\begin{array}{l}\text { ref|Danio rerio cytokine inducible SH2- } \\
\text { containing protein (cish), mRNA } \\
\text { [NM_001076617] }\end{array}$ & -0.70 & $2.41 \mathrm{E}-05$ \\
\hline сур $2 p 9$ & $\begin{array}{l}\text { ref|Danio rerio cytochrome P450, family } \\
\text { 2, subfamily P, polypeptide } 9 \text { (cyp2p9), } \\
\text { mRNA [NM_200620] }\end{array}$ & -0.70 & $2.93 \mathrm{E}-02$ \\
\hline psma4 & $\begin{array}{l}\text { ref|Danio rerio proteasome subunit alpha } \\
4 \text { (psma4), mRNA [NM_214697] }\end{array}$ & -0.70 & $3.35 \mathrm{E}-03$ \\
\hline
\end{tabular}


ref|Danio rerio intelectin 3 (itln3), mRNA

\begin{tabular}{|c|c|c|c|}
\hline$i t \ln 3$ & [NM_001159584] & -0.70 & $2.55 \mathrm{E}-04$ \\
\hline or126-2 & $\begin{array}{l}\text { ref|Danio rerio odorant receptor, family E, } \\
\text { subfamily 126, member } 2 \text { (or126-2), } \\
\text { mRNA [NM_001128397] }\end{array}$ & -0.71 & $1.86 \mathrm{E}-03$ \\
\hline ngs & $\begin{array}{l}\text { ref|Danio rerio notochord granular surface } \\
\text { (ngs), mRNA [NM_001128765] }\end{array}$ & -0.71 & $1.75 \mathrm{E}-03$ \\
\hline arl3l2 & $\begin{array}{l}\text { ref|Danio rerio ADP-ribosylation factor- } \\
\text { like 3, like 2(arl312), mRNA } \\
\text { [NM_200719] }\end{array}$ & -0.71 & $2.51 \mathrm{E}-05$ \\
\hline sncga & $\begin{array}{l}\text { ref|'Danio rerio synuclein, gamma a } \\
\text { (sncga), mRNA [NM_001017567] }\end{array}$ & -0.71 & 2.07E-04 \\
\hline tmem $237 b$ & $\begin{array}{l}\text { ref|Danio rerio transmembrane protein } \\
\text { 237b (tmem237b), mRNA } \\
\text { [NM_001004636] }\end{array}$ & -0.71 & 7.45E-03 \\
\hline $\operatorname{lmnl3}$ & $\begin{array}{l}\text { ref|Danio rerio lamin L3 (lmnl3), mRNA } \\
\text { [NM_152973] }\end{array}$ & -0.72 & 4.24E-02 \\
\hline stm & $\begin{array}{l}\text { ref|Danio rerio starmaker (stm), mRNA } \\
\text { [NM_198817] }\end{array}$ & -0.72 & $5.20 \mathrm{E}-04$ \\
\hline$a r r 3 a$ & $\begin{array}{l}\text { ref|Danio rerio arrestin 3a, retinal }(\mathrm{X}- \\
\text { arrestin) }(\operatorname{arr} 3 \mathrm{a}), \mathrm{mRNA} \\
{\left[\mathrm{NM} \_001002405\right]}\end{array}$ & -0.72 & $3.46 \mathrm{E}-02$ \\
\hline sult1st6 & $\begin{array}{l}\text { ref|Danio rerio sulfotransferase family } 1, \\
\text { cytosolic sulfotransferase } 6 \text { (sult1st6), } \\
\text { mRNA [NM_001002599] }\end{array}$ & -0.72 & $9.50 \mathrm{E}-06$ \\
\hline cts 12 & $\begin{array}{l}\text { ens|cathepsin } 12 \text { [Source:ZFIN;Acc:ZDB- } \\
\text { GENE-050208-336] } \\
\text { [ENSDART00000062749] }\end{array}$ & -0.73 & $1.30 \mathrm{E}-04$ \\
\hline kcnh3 & $\begin{array}{l}\text { ens|potassium voltage-gated channel, } \\
\text { subfamily H (eag-related), member } 3 \\
\text { [Source:ZFIN;Acc:ZDB-GENE-070912- } \\
\text { 23] [ENSDART00000146284] }\end{array}$ & -0.73 & $2.93 \mathrm{E}-03$ \\
\hline zgc:112492 & $\begin{array}{l}\text { ref|Danio rerio zgc: } 112492 \text { (zgc:112492), } \\
\text { mRNA [NM_001017658] }\end{array}$ & -0.73 & $2.59 \mathrm{E}-04$ \\
\hline zgc:172079 & $\begin{array}{l}\text { ref|Danio rerio zgc:172079 (zgc:172079), } \\
\text { mRNA [NM_001113340] }\end{array}$ & -0.73 & 7.67E-04 \\
\hline pkp1b & $\begin{array}{l}\text { ens|plakophilin 1b } \\
\text { [Source:ZFIN;Acc:ZDB-GENE-030131- } \\
\text { 417] [ENSDART00000074605] }\end{array}$ & -0.74 & $8.78 \mathrm{E}-07$ \\
\hline nme2a & $\begin{array}{l}\text { ref|Danio rerio NME/NM23 nucleoside } \\
\text { diphosphate kinase 2a (nme2a), mRNA } \\
\text { [NM_199970] }\end{array}$ & -0.74 & $2.18 \mathrm{E}-02$ \\
\hline$z g c: 112302$ & $\begin{array}{l}\text { ref|Danio rerio zgc:112302 (zgc:112302), } \\
\text { mRNA [NM_001025187] }\end{array}$ & -0.74 & $1.32 \mathrm{E}-04$ \\
\hline fads2 & $\begin{array}{l}\text { ref|Danio rerio fatty acid desaturase } 2 \\
\text { (fads2), mRNA [NM_131645] }\end{array}$ & -0.74 & $2.60 \mathrm{E}-04$ \\
\hline
\end{tabular}


ref|Danio rerio starmaker (stm), mRNA

\begin{tabular}{|c|c|c|c|}
\hline stm & [NM_198817] & -0.74 & $2.92 \mathrm{E}-03$ \\
\hline matn3a & $\begin{array}{l}\text { ref|Danio rerio matrilin 3a (matn3a), } \\
\text { transcript variant 1, mRNA } \\
\text { [NM_001004007] }\end{array}$ & -0.74 & 2.23E-04 \\
\hline$s a g b$ & $\begin{array}{l}\text { ref|Danio rerio S-antigen; retina and } \\
\text { pineal gland (arrestin) b (sagb), mRNA } \\
\text { [NM_001033749] }\end{array}$ & -0.75 & $2.77 \mathrm{E}-03$ \\
\hline$o p n 1 m w 2$ & $\begin{array}{l}\text { ref|Danio rerio opsin } 1 \text { (cone pigments), } \\
\text { medium-wave-sensitive, } 2 \text { (opn1mw2), } \\
\text { mRNA [NM_182891] }\end{array}$ & -0.75 & $3.03 \mathrm{E}-03$ \\
\hline matn $3 a$ & $\begin{array}{l}\text { tc|Rep: Matrilin-3a precursor - Danio } \\
\text { rerio (Zebrafish) (Brachydanio rerio), } \\
\text { complete [TC370620] }\end{array}$ & -0.75 & 4.34E-03 \\
\hline trappc13 & $\begin{array}{l}\text { ref|Danio rerio trafficking protein particle } \\
\text { complex } 13 \text { (trappc13), transcript variant } \\
\text { 2, mRNA [NM_199538] }\end{array}$ & -0.75 & $1.23 \mathrm{E}-02$ \\
\hline TC387531 & $\begin{array}{l}\text { tc|Rep: Chromosome undetermined } \\
\text { SCAF14702, whole genome shotgun } \\
\text { sequence - Tetraodon nigroviridis (Green } \\
\text { puffer), partial (56\%) [TC387531] }\end{array}$ & -0.75 & $1.18 \mathrm{E}-02$ \\
\hline cish & $\begin{array}{l}\text { ref|Danio rerio cytokine inducible SH2- } \\
\text { containing protein (cish), mRNA } \\
\text { [NM_001076617] }\end{array}$ & -0.75 & $5.20 \mathrm{E}-04$ \\
\hline$r g s 9 a$ & $\begin{array}{l}\text { ref|Danio rerio regulator of } \mathrm{G} \text { protein } \\
\text { signaling } 9 \mathrm{a}(\mathrm{rgs} 9 \mathrm{a}), \mathrm{mRNA} \\
\text { [NM_001327800] }\end{array}$ & -0.76 & $1.60 \mathrm{E}-03$ \\
\hline$c b \ln 13$ & $\begin{array}{l}\text { ref|Danio rerio cerebellin } 13 \text { (cbln13), } \\
\text { mRNA [NM_001123061] }\end{array}$ & -0.76 & $5.28 \mathrm{E}-04$ \\
\hline rho & $\begin{array}{l}\text { ref|Danio rerio rhodopsin (rho), mRNA } \\
\text { [NM_131084] }\end{array}$ & -0.76 & $1.21 \mathrm{E}-02$ \\
\hline cst14b.1 & $\begin{array}{l}\text { ref|Danio rerio cystatin 14b, tandem } \\
\text { duplicate } 1 \text { (cst14b.1), mRNA } \\
\text { [NM_001077274] }\end{array}$ & -0.76 & 2.03E-03 \\
\hline syt5a & $\begin{array}{l}\text { ref|Danio rerio synaptotagmin Va (syt5a), } \\
\text { mRNA [NM_001103137] }\end{array}$ & -0.76 & $1.38 \mathrm{E}-02$ \\
\hline si:ch211-81a5.8 & $\begin{array}{l}\text { ref|Danio rerio si:ch211-81a5.8 (si:ch211- } \\
\text { 81a5.8), mRNA [NM_001044935] }\end{array}$ & -0.77 & $5.27 \mathrm{E}-03$ \\
\hline$p d c b$ & $\begin{array}{l}\text { ref|Danio rerio phosducin b (pdcb), } \\
\text { mRNA [NM_001025464] }\end{array}$ & -0.77 & $9.89 \mathrm{E}-03$ \\
\hline $\operatorname{tm} 4 s f 4$ & $\begin{array}{l}\text { ref|Danio rerio transmembrane } 4 \mathrm{~L} \text { six } \\
\text { family member } 4(\mathrm{tm} 4 \mathrm{sf} 4), \text { mRNA } \\
\text { [NM_001003489] }\end{array}$ & -0.77 & $9.47 \mathrm{E}-03$ \\
\hline duox & $\begin{array}{l}\text { ens|dual oxidase [Source:ZFIN;Acc:ZDB- } \\
\text { GENE-091117-14] } \\
\text { [ENSDART00000090727] }\end{array}$ & -0.77 & $4.09 \mathrm{E}-03$ \\
\hline
\end{tabular}


ref|Danio rerio adipocyte plasma

membrane associated protein (apmap),

apmap

mRNA [NM_212608]

$-0.77$

$5.47 \mathrm{E}-03$

ref|Danio rerio olfactomedin 1a (olfm1a),

transcript variant 2 , mRNA

olfm1a

[NM_001327880]

$-0.77$

9.74E-03

ref|Danio rerio U2 small nuclear

ribonucleoprotein auxiliary factor $35 \mathrm{kDa}$

subunit-related protein 1-like

(LOC100331497), mRNA

LOC100331497

[NM_001327888]

$-0.78$

8.16E-04

ref|Danio rerio S100 calcium binding

protein A11 (s100a11), mRNA

s100a11

[NM_001282183]

$-0.78$

3.50E-05

ref|Danio rerio aldolase $\mathrm{C}$, fructose-

bisphosphate, a (aldoca), mRNA

aldoca

[NM_001029952]

$-0.78$

4.33E-06

tc|GB|XM_001922300.1|XP_001922335.

1 similar to serine hydrolase-like

NP13317243

[NP13317243]

$-0.78$

2.05E-03

ref|Danio rerio zgc:77748 (zgc:77748),

zgc:77748

mRNA [NM_200858]

$-0.80$

8.89E-05

anxa2b

Unknown

$-0.80$

$5.93 \mathrm{E}-04$

gb|FDR103-P00025-DEPE-F_I03

FDR 103 Danio rerio cDNA clone

FDR103-P00025-BR_I03 5', mRNA

EH440526

sequence [EH440526]

$-0.81$

1.14E-04

ens|si:dkey-21e2.15

[Source:ZFIN;Acc:ZDB-GENE-050208-

si:dkey-21e2.15

780] [ENSDART00000132386] $-0.81$

$1.36 \mathrm{E}-03$

ref|Danio rerio villin 1 (vil1), mRNA

vil1

[NM_200238]

$-0.81$

$2.38 \mathrm{E}-03$

ref|Danio rerio homeobox C12a

hoxc12a

(hoxc12a), mRNA [NM_001110759]

$-0.81$

3.15E-03

ref|Danio rerio fructose-1,6-

bisphosphatase 2 (fbp2), mRNA

\begin{tabular}{llll} 
fbp2 & [NM_001004008] & -0.82 & $4.49 \mathrm{E}-03$ \\
\hline & tc|GB|XM_001920642.1|XP_001920677. & & \\
NP13318126 & 1 similar to butyrophilin, subfamily 2, & & \\
& member A2 [NP13318126] & -0.82 & $8.91 \mathrm{E}-03$ \\
\hline & $\begin{array}{l}\text { ens|si:ch73-288o11.5 } \\
\text { [Source:ZFIN;Acc:ZDB-GENE-131121- }\end{array}$ & & \\
si:ch73-288011.5 & 416] [ENSDART00000154123] & -0.82 & $2.36 \mathrm{E}-10$ \\
\hline \multirow{2}{*}{ gng13a } & ref|Danio rerio guanine nucleotide & & \\
& binding protein (G protein), gamma 13a & -0.82 & \multirow{2}{*}{$1.47 \mathrm{E}-04$}
\end{tabular}


(gng13a), transcript variant 1, mRNA

[NM_001166125]

ens|si:dkey-21e2.15

[Source:ZFIN;Acc:ZDB-GENE-050208-

si:dkey-21e2.15

780] [ENSDART00000137976]

$-0.83 \quad 4.07 \mathrm{E}-04$

ref|Danio rerio mitochondrial translational

initiation factor 3 (mtif3), mRNA

mtif3

[NM_001326363]

$-0.83$

$2.25 \mathrm{E}-02$

ref|Danio rerio phosducin $\mathrm{b}$ (pdcb),

$p d c b$

mRNA [NM_001025464]

$-0.83$

2.04E-03

ref|Danio rerio starmaker (stm), mRNA

$\begin{array}{ll}\text { stm } & \text { [NM_198817] } \\ & \text { ref|Danio rerio zgc:172065 (zgc:172065), }\end{array}$

zgc:172065

mRNA [NM_001114719]

$-0.84$

2.87E-05

ref|Danio rerio annexin A2b (anxa2b),

anxa $2 b$

mRNA [NM_001105600] $-0.84$

$2.98 \mathrm{E}-03$

ref|Danio rerio protein disulfide

isomerase family $\mathrm{A}$, member 2 (pdia2),

pdia2

mRNA [NM_001320534]

$-0.85$

7.73E-04

ref|Danio rerio guanine nucleotide

binding protein (G protein), alpha

transducing activity polypeptide 2

$\underline{\text { gnat2 }}$

(gnat2), mRNA [NM_131869]

$-0.85$

$1.13 \mathrm{E}-02$

ens|si:dkey-52d15.2 [Source:NCBI

gene;Acc:100006993]

si:dkey-52d15.2

[ENSDART00000142311]

$-0.85$

$2.38 \mathrm{E}-02$

ref|Danio rerio carboxypeptidase B1

(tissue) (cpb1), transcript variant 2,

$c p b 1$

mRNA [NM_001110021]

$-0.85$

5.77E-05

ref|Danio rerio aminoadipate-

semialdehyde dehydrogenase-

phosphopantetheinyl transferase

aasdhppt

(aasdhppt), mRNA [NM_001033729]

$-0.86$

1.77E-02

ref|Danio rerio fatty acid binding protein

10a, liver basic (fabp10a), mRNA

fabp10a

[NM_152960]

$-0.86$

$2.54 \mathrm{E}-02$

ref|Danio rerio perforin 1.1 (prf1.1),

prf1.1

mRNA [NM_001317762]

$-0.86$

6.16E-04

ref|Danio rerio solute carrier family 38 ,

member 11 (slc38a11), mRNA

slc38a11

[NM_001017644]

$-0.86$

2.71E-04

ref|Danio rerio zgc:112160 (zgc:112160),

zgc:112160

mRNA [NM_001017724]

$-0.86$

$3.90 \mathrm{E}-03$

ens|si:ch1073-303d10.1

[Source:ZFIN;Acc:ZDB-GENE-141216-

si:ch1073-303d10.1

327] [ENSDART00000171854]

$-0.87$

3.54E-03 


\begin{tabular}{|c|c|c|c|}
\hline$z g c: 158846$ & $\begin{array}{l}\text { ref|Danio rerio zgc:158846 (zgc:158846), } \\
\text { mRNA [NM_001083023] }\end{array}$ & -0.87 & $1.08 \mathrm{E}-02$ \\
\hline zgc:165515 & $\begin{array}{l}\text { ref|Danio rerio zgc:165515 (zgc:165515), } \\
\text { mRNA [NM_001099227] }\end{array}$ & -0.87 & $1.45 \mathrm{E}-02$ \\
\hline si:dkeyp-73d8.6 & $\begin{array}{l}\text { ref|Danio rerio si:dkeyp-73d8.6 (si:dkeyp- } \\
\text { 73d8.6), mRNA [NM_001130644] }\end{array}$ & -0.87 & $3.45 \mathrm{E}-03$ \\
\hline scpp5 & $\begin{array}{l}\text { ref|Danio rerio secretory calcium-binding } \\
\text { phosphoprotein } 5 \text { (scpp5), mRNA } \\
\text { [NM_001145236] }\end{array}$ & -0.87 & $6.39 \mathrm{E}-03$ \\
\hline ela3l & $\begin{array}{l}\text { ref|Danio rerio elastase } 3 \text { like (ela31), } \\
\text { mRNA [NM_001024408] }\end{array}$ & -0.88 & $3.39 \mathrm{E}-05$ \\
\hline si:ch211-285j22.3 & $\begin{array}{l}\text { ref|Danio rerio si:ch211-285j22.3 } \\
\text { (si:ch211-285j22.3), long non-coding } \\
\text { RNA [NR_120357] }\end{array}$ & -0.88 & $9.01 \mathrm{E}-03$ \\
\hline cish & $\begin{array}{l}\text { ref|Danio rerio cytokine inducible SH2- } \\
\text { containing protein (cish), mRNA } \\
\text { [NM_001076617] }\end{array}$ & -0.88 & 4.18E-06 \\
\hline zgc:193593 & $\begin{array}{l}\text { ref|Danio rerio zgc:193593 (zgc:193593), } \\
\text { mRNA [NM_001128717] }\end{array}$ & -0.88 & $9.40 \mathrm{E}-03$ \\
\hline spaca4l & $\begin{array}{l}\text { ens|sperm acrosome associated } 4 \text { like } \\
\text { [Source:ZFIN;Acc:ZDB-GENE-101011- } \\
\text { 2] [ENSDART00000188868] }\end{array}$ & -0.88 & 4.51E-02 \\
\hline prph $2 a$ & $\begin{array}{l}\text { ref|Danio rerio peripherin 2a (retinal } \\
\text { degeneration, slow) (prph2a), mRNA } \\
\text { [NM_131566] }\end{array}$ & -0.88 & $5.19 \mathrm{E}-03$ \\
\hline TC382187 & $\begin{array}{l}\text { tc|Rep: Zgc: } 158224 \text { protein - Danio rerio } \\
\text { (Zebrafish) (Brachydanio rerio), complete } \\
\text { [TC382187] }\end{array}$ & -0.89 & $6.76 \mathrm{E}-04$ \\
\hline ppala & $\begin{array}{l}\text { ref|Danio rerio pyrophosphatase } \\
\text { (inorganic) 1a (ppa1a), mRNA } \\
\text { [NM_200733] }\end{array}$ & -0.89 & $1.50 \mathrm{E}-03$ \\
\hline rcvrn3 & $\begin{array}{l}\text { ref|Danio rerio recoverin } 3 \text { (rcvrn3), } \\
\text { mRNA [NM_200825] }\end{array}$ & -0.90 & $8.89 \mathrm{E}-03$ \\
\hline si:ch211-103n10.5 & $\begin{array}{l}\text { ens|si:ch211-103n10.5 } \\
\text { [Source:ZFIN;Acc:ZDB-GENE-030131- } \\
\text { 5155] [ENSDART00000188165] }\end{array}$ & -0.91 & $7.57 \mathrm{E}-03$ \\
\hline сра4 & $\begin{array}{l}\text { ref|Danio rerio carboxypeptidase A4 } \\
\text { (cpa4), mRNA [NM_001002217] }\end{array}$ & -0.91 & $3.20 \mathrm{E}-03$ \\
\hline si:ch73-306e8.2 & $\begin{array}{l}\text { ens|si:ch73-306e8.2 } \\
\text { [Source:ZFIN;Acc:ZDB-GENE-131121- } \\
\text { 409] [ENSDART00000153515] }\end{array}$ & -0.91 & $2.20 \mathrm{E}-10$ \\
\hline rp1l1b & $\begin{array}{l}\text { ens|retinitis pigmentosa 1-like 1b } \\
\text { [Source:ZFIN;Acc:ZDB-GENE-091204- } \\
\text { 67] [ENSDART00000151881] }\end{array}$ & -0.91 & $1.18 \mathrm{E}-03$ \\
\hline anxalb & $\begin{array}{l}\text { ref|Danio rerio annexin A1b (anxa1b), } \\
\text { mRNA [NM_181759] }\end{array}$ & -0.92 & $3.76 \mathrm{E}-05$ \\
\hline
\end{tabular}


ens|si:dkey-17e16.15

\begin{tabular}{|c|c|c|c|}
\hline $\begin{array}{l}\text { ENSDART0000013401 } \\
7\end{array}$ & $\begin{array}{l}\text { [Source:ZFIN;Acc:ZDB-GENE-091204- } \\
\text { 295] [ENSDART00000134017] }\end{array}$ & -0.93 & $1.01 \mathrm{E}-03$ \\
\hline syt $5 a$ & $\begin{array}{l}\text { ref|Danio rerio synaptotagmin Va (syt5a), } \\
\text { mRNA [NM_001103137] }\end{array}$ & -0.93 & $6.24 \mathrm{E}-03$ \\
\hline EH440526 & $\begin{array}{l}\text { gb|FDR103-P00025-DEPE-F_I03 } \\
\text { FDR103 Danio rerio cDNA clone } \\
\text { FDR103-P00025-BR_I03 5', mRNA } \\
\text { sequence [EH440526] }\end{array}$ & -0.93 & $6.79 \mathrm{E}-05$ \\
\hline $\operatorname{sgcg}$ & $\begin{array}{l}\text { ens|sarcoglycan, gamma } \\
\text { [Source:ZFIN;Acc:ZDB-GENE-030724- } \\
\text { 2] [ENSDART00000144381] }\end{array}$ & -0.93 & $2.29 \mathrm{E}-02$ \\
\hline$o p n 1 m w 2$ & $\begin{array}{l}\text { ref|Danio rerio opsin } 1 \text { (cone pigments), } \\
\text { medium-wave-sensitive, } 2 \text { (opn1mw2), } \\
\text { mRNA [NM_182891] }\end{array}$ & -0.94 & $6.87 \mathrm{E}-03$ \\
\hline cpa4 & $\begin{array}{l}\text { ref|Danio rerio carboxypeptidase A4 } \\
\text { (cpa4), mRNA [NM_001002217] }\end{array}$ & -0.95 & $1.97 \mathrm{E}-03$ \\
\hline$h m g b 2 a$ & $\begin{array}{l}\text { ref|Danio rerio high mobility group box } \\
\text { 2a (hmgb2a), mRNA [NM_001037424] }\end{array}$ & -0.95 & 4.12E-02 \\
\hline si:dkey-78l4.8 & $\begin{array}{l}\text { ens|si:dkey-7814.8 } \\
\text { [Source:ZFIN;Acc:ZDB-GENE-060503- } \\
\text { 270] [ENSDART00000136576] }\end{array}$ & -0.96 & 2.87E-03 \\
\hline$c b x 5$ & $\begin{array}{l}\text { ref|Danio rerio chromobox homolog } 5 \\
\text { (HP1 alpha homolog, Drosophila) (cbx5), } \\
\text { mRNA [NM_001080184] }\end{array}$ & -0.96 & $1.60 \mathrm{E}-02$ \\
\hline gucalc & $\begin{array}{l}\text { ref|Danio rerio guanylate cyclase } \\
\text { activator 1C (guca1c), mRNA } \\
\text { [NM_194393] }\end{array}$ & -0.97 & $2.71 \mathrm{E}-04$ \\
\hline selenoe & $\begin{array}{l}\text { ref|Danio rerio selenoprotein e (selenoe), } \\
\text { mRNA [NM_001195784] }\end{array}$ & -0.97 & $1.98 \mathrm{E}-03$ \\
\hline ppa2 & $\begin{array}{l}\text { ref|Danio rerio pyrophosphatase } \\
\text { (inorganic) } 2(\mathrm{ppa} 2), \text { mRNA } \\
\text { [NM_205662] }\end{array}$ & -0.97 & $1.22 \mathrm{E}-02$ \\
\hline pde6hb & $\begin{array}{l}\text { ref|Danio rerio phosphodiesterase } 6 \mathrm{H} \text {, } \\
\text { cGMP-specific, cone, gamma, paralog b } \\
\text { (pde6hb), mRNA [NM_200837] }\end{array}$ & -0.97 & $6.84 \mathrm{E}-03$ \\
\hline prss1 & $\begin{array}{l}\text { ref|Danio rerio serine protease } 1 \text { (prss1), } \\
\text { mRNA [NM_131708] }\end{array}$ & -0.97 & $1.09 \mathrm{E}-02$ \\
\hline grk7a & $\begin{array}{l}\text { ref|Danio rerio G protein-coupled } \\
\text { receptor kinase 7a (grk7a), mRNA } \\
{[\mathrm{NM} \text {-001031841] }}\end{array}$ & -0.98 & $1.27 \mathrm{E}-02$ \\
\hline$a r r 3 b$ & $\begin{array}{l}\text { ref|Danio rerio arrestin 3b, retinal (X- } \\
\text { arrestin) (arr3b), mRNA [NM_200792] }\end{array}$ & -0.98 & $1.33 \mathrm{E}-02$ \\
\hline si:ch211-285j22.3 & $\begin{array}{l}\text { ref|Danio rerio si:ch211-285j22.3 } \\
\text { (si:ch211-285j22.3), long non-coding } \\
\text { RNA [NR_120357] }\end{array}$ & -0.98 & $3.20 \mathrm{E}-03$ \\
\hline
\end{tabular}


ref|Danio rerio retinol binding protein 3

\begin{tabular}{|c|c|c|c|}
\hline rbp3 & (rbp3), mRNA [NM_131451] & -0.98 & $2.42 \mathrm{E}-03$ \\
\hline slc25a3a & $\begin{array}{l}\text { ref|Danio rerio solute carrier family } 25 \\
\text { (mitochondrial carrier; phosphate carrier), } \\
\text { member 3a (slc25a3a), transcript variant } \\
\text { 2, mRNA [NM_200715] }\end{array}$ & -0.99 & 3.63E-03 \\
\hline ctrb1 & $\begin{array}{l}\text { ref|Danio rerio chymotrypsinogen B1 } \\
\text { (ctrb1), mRNA [NM_212618] }\end{array}$ & -0.99 & $1.89 \mathrm{E}-03$ \\
\hline tcnba & $\begin{array}{l}\text { ref|Danio rerio transcobalamin like (tcnl), } \\
\text { mRNA [NM_001128735] }\end{array}$ & -0.99 & 3.62E-04 \\
\hline galns & $\begin{array}{l}\text { ref|Danio rerio galactosamine (N-acetyl)- } \\
\text { 6-sulfatase (galns), mRNA } \\
\text { [NM_001080641] }\end{array}$ & -1.00 & $5.48 \mathrm{E}-03$ \\
\hline opn1lw2 & $\begin{array}{l}\text { ref|Danio rerio opsin } 1 \text { (cone pigments), } \\
\text { long-wave-sensitive, } 2 \text { (opn1lw2), mRNA } \\
\text { [NM_001002443] }\end{array}$ & -1.01 & $1.12 \mathrm{E}-02$ \\
\hline gnat2 & $\begin{array}{l}\text { ref|Danio rerio guanine nucleotide } \\
\text { binding protein (G protein), alpha } \\
\text { transducing activity polypeptide } 2 \\
\text { (gnat2), mRNA [NM_131869] }\end{array}$ & -1.02 & 4.10E-02 \\
\hline aqp8a.2 & $\begin{array}{l}\text { ref|Danio rerio aquaporin 8a, tandem } \\
\text { duplicate } 2 \text { (aqp8a.2), mRNA } \\
\text { [NM_001080182] }\end{array}$ & -1.02 & $1.58 \mathrm{E}-03$ \\
\hline arr $3 b$ & $\begin{array}{l}\text { ref|Danio rerio arrestin 3b, retinal (X- } \\
\text { arrestin) (arr3b), mRNA [NM_200792] }\end{array}$ & -1.03 & $6.60 \mathrm{E}-03$ \\
\hline si:ch211-119o8.7 & $\begin{array}{l}\text { ref|Danio rerio si:ch211-119o8.7 } \\
\text { (si:ch211-119o8.7), mRNA } \\
\text { [NM_001114899] }\end{array}$ & -1.03 & $2.14 \mathrm{E}-03$ \\
\hline$z g c: 195245$ & $\begin{array}{l}\text { ref|Danio rerio zgc:195245 (zgc:195245), } \\
\text { mRNA [NM_001126422] }\end{array}$ & -1.04 & 5.57E-04 \\
\hline prph $2 b$ & $\begin{array}{l}\text { ref|Danio rerio peripherin } 2 b \text { (retinal } \\
\text { degeneration, slow) (prph2b), mRNA } \\
{[\text { NM_131567] }}\end{array}$ & -1.04 & $5.25 \mathrm{E}-03$ \\
\hline grk7a & $\begin{array}{l}\text { ref|Danio rerio G protein-coupled } \\
\text { receptor kinase 7a (grk7a), mRNA } \\
\text { [NM_001031841] }\end{array}$ & -1.04 & 4.89E-04 \\
\hline$p d c b$ & $\begin{array}{l}\text { ref|Danio rerio phosducin b (pdcb), } \\
\text { mRNA [NM_001025464] }\end{array}$ & -1.06 & $1.04 \mathrm{E}-02$ \\
\hline gucalc & $\begin{array}{l}\text { ref|Danio rerio guanylate cyclase } \\
\text { activator 1C (guca1c), mRNA } \\
\text { [NM_194393] }\end{array}$ & -1.08 & $1.83 \mathrm{E}-04$ \\
\hline pde6c & $\begin{array}{l}\text { ref|Danio rerio phosphodiesterase 6C, } \\
\text { cGMP-specific, cone, alpha prime } \\
\text { (pde6c), mRNA [NM_200871] }\end{array}$ & -1.09 & 2.93E-02 \\
\hline
\end{tabular}


ref|Danio rerio opsin 1 (cone pigments),

short-wave-sensitive 2 (opn1sw2), mRNA

\begin{tabular}{|c|c|c|c|}
\hline opn1sw2 & [NM_131192] & -1.10 & $1.02 \mathrm{E}-02$ \\
\hline ela2 & $\begin{array}{l}\text { ref|Danio rerio elastase } 2 \text { (ela2), mRNA } \\
\text { [NM_001139464] }\end{array}$ & -1.11 & $8.39 \mathrm{E}-03$ \\
\hline sult3st4 & $\begin{array}{l}\text { ref|Danio rerio sulfotransferase family 3, } \\
\text { cytosolic sulfotransferase } 4 \text { (sult3st4), } \\
\text { mRNA [NM_001308830] }\end{array}$ & -1.14 & $1.66 \mathrm{E}-09$ \\
\hline $\operatorname{tgm} 114$ & $\begin{array}{l}\text { ref|Danio rerio transglutaminase } 1 \text { like } 4 \\
\text { (tgm114), mRNA [NM_001030096] }\end{array}$ & -1.14 & $1.62 \mathrm{E}-04$ \\
\hline $\operatorname{tms} b 4 x$ & $\begin{array}{l}\text { ref|Danio rerio thymosin beta } 4 \text { X-linked } \\
\text { (tmsb4x), mRNA [NM_001130697] }\end{array}$ & -1.14 & $1.01 \mathrm{E}-03$ \\
\hline pde6hb & $\begin{array}{l}\text { ref|Danio rerio phosphodiesterase } 6 \mathrm{H}, \\
\text { cGMP-specific, cone, gamma, paralog b } \\
\text { (pde6hb), mRNA [NM_200837] }\end{array}$ & -1.15 & $2.72 \mathrm{E}-03$ \\
\hline cpa5 & $\begin{array}{l}\text { ref|Danio rerio carboxypeptidase A5 } \\
\text { (cpa5), mRNA [NM_199271] }\end{array}$ & -1.15 & 7.67E-04 \\
\hline cpa5 & $\begin{array}{l}\text { ref|Danio rerio carboxypeptidase A5 } \\
\text { (cpa5), mRNA [NM_199271] }\end{array}$ & -1.17 & 2.07E-04 \\
\hline gnb3b & $\begin{array}{l}\text { ref|Danio rerio guanine nucleotide } \\
\text { binding protein (G protein), beta } \\
\text { polypeptide } 3 b \text { (gnb3b), mRNA } \\
\text { [NM_213202] }\end{array}$ & -1.19 & $1.03 \mathrm{E}-02$ \\
\hline ctrl & $\begin{array}{l}\text { ref|Danio rerio chymotrypsin-like (ctrl), } \\
\text { mRNA [NM_001004582] }\end{array}$ & -1.19 & $1.86 \mathrm{E}-03$ \\
\hline gnat2 & $\begin{array}{l}\text { ref|Danio rerio guanine nucleotide } \\
\text { binding protein (G protein), alpha } \\
\text { transducing activity polypeptide } 2 \\
\text { (gnat2), mRNA [NM_131869] }\end{array}$ & -1.19 & $1.17 \mathrm{E}-02$ \\
\hline rcvrn3 & $\begin{array}{l}\text { ref|Danio rerio recoverin } 3 \text { (rcvrn3), } \\
\text { mRNA [NM_200825] }\end{array}$ & -1.21 & $6.51 \mathrm{E}-03$ \\
\hline $\operatorname{tgm} 114$ & $\begin{array}{l}\text { ref|Danio rerio transglutaminase } 1 \text { like } 4 \\
\text { (tgm114), mRNA [NM_001030096] }\end{array}$ & -1.21 & $5.99 \mathrm{E}-05$ \\
\hline setdb1a & $\begin{array}{l}\text { ref|Danio rerio SET domain, bifurcated 1a } \\
\text { (setdb1a), mRNA [NM_001044767] }\end{array}$ & -1.22 & $1.15 \mathrm{E}-02$ \\
\hline prss1 & $\begin{array}{l}\text { ref|Danio rerio serine protease } 1 \text { (prss1), } \\
\text { mRNA [NM_131708] }\end{array}$ & -1.23 & $2.74 \mathrm{E}-04$ \\
\hline apoda.2 & $\begin{array}{l}\text { ref|Danio rerio apolipoprotein Da, } \\
\text { duplicate } 2 \text { (apoda.2), transcript variant } 1 \text {, } \\
\text { mRNA [NM_001201348] }\end{array}$ & -1.24 & $2.84 \mathrm{E}-04$ \\
\hline sult3st3 & $\begin{array}{l}\text { ref|Danio rerio sulfotransferase family } 3 \text {, } \\
\text { cytosolic sulfotransferase } 3 \text { (sult3st3), } \\
\text { mRNA [NM_001082876] }\end{array}$ & -1.26 & $9.71 \mathrm{E}-09$ \\
\hline$g n b 3 b$ & $\begin{array}{l}\text { ref|Danio rerio guanine nucleotide } \\
\text { binding protein (G protein), beta }\end{array}$ & -1.28 & $8.94 \mathrm{E}-03$ \\
\hline
\end{tabular}


polypeptide $3 \mathrm{~b}$ (gnb3b), mRNA

[NM_213202]

ref|Danio rerio opsin 1 (cone pigments),

medium-wave-sensitive, 1 (opn1mw1),

opn1mw1

mRNA [NM_131253]

$-1.29$

1.47E-02

ref|Danio rerio $\mathrm{G}$ protein-coupled

receptor kinase $1 \mathrm{~b}$ (grk1b), mRNA

grk1b

[NM_001017711]

$-1.31$

$3.65 \mathrm{E}-03$

ref|Danio rerio opsin 1 (cone pigments),

medium-wave-sensitive, 1 (opn1mw1),

opn1mw1

mRNA [NM_131253]

$-1.31$

1.69E-02

ref|Danio rerio guanine nucleotide

binding protein ( $\mathrm{G}$ protein), beta

polypeptide $3 \mathrm{~b}$ (gnb3b), mRNA

$\underline{g n b 3 b}$

[NM_213202]

$-1.31$

$1.08 \mathrm{E}-02$

ref|Danio rerio phosphodiesterase $6 \mathrm{H}$,

cGMP-specific, cone, gamma, paralog a

(pde6ha), transcript variant 2, mRNA

pde6ha

[NM_200785]

$-1.35$

$3.49 \mathrm{E}-02$

ref|Danio rerio opsin 1 (cone pigments),

short-wave-sensitive 1 (opn1sw1), mRNA

opn1sw1

[NM_131319]

$-1.37$

2.81E-03

ref|Danio rerio opsin 1 (cone pigments),

short-wave-sensitive 1 (opn1sw1), mRNA

opn1sw1

[NM_131319]

$-1.38$

4.60E-03

ref|Danio rerio guanine nucleotide

binding protein ( $\mathrm{G}$ protein), beta

polypeptide $3 \mathrm{~b}$ (gnb3b), mRNA

$\underline{g n b 3 b}$

[NM_213202]

$-1.38$

ref|Danio rerio guanine nucleotide

binding protein ( $\mathrm{G}$ protein), beta

polypeptide $3 \mathrm{~b}$ (gnb3b), mRNA

$\underline{\text { gnb3b }}$

[NM_213202]

$-1.39$

3.81E-03

ens|phosphodiesterase 6H, cGMP-

specific, cone, gamma, paralog a

ENSDART0000016259 [Source:ZFIN;Acc:ZDB-GENE-040426-

\begin{tabular}{llll}
9 & $1754]$ [ENSDART00000162599] & -1.39 & $3.05 \mathrm{E}-02$ \\
\hline & ref|Danio rerio chymotrypsinogen B1 &
\end{tabular}

\begin{tabular}{llll}
$\boldsymbol{c t r b 1}$ & (ctrb1), mRNA [NM_212618] & -1.41 & $9.17 \mathrm{E}-04$ \\
\hline
\end{tabular}

ref|Danio rerio serine protease 59, tandem

duplicate 1 (prss59.1), mRNA

prss59.1

[NM_199605]

$-1.48$

4.49E-04

ref|Danio rerio desmin a (desma),

transcript variant 2, mRNA

desma

[NM_001328376]

$-1.49$

$5.74 \mathrm{E}-03$ 
ref|Danio rerio sulfotransferase family 3,

cytosolic sulfotransferase 3 (sult3st3),

\begin{tabular}{|c|c|c|c|}
\hline sult3st3 & mRNA [NM_001082876] & -1.50 & $4.70 \mathrm{E}-08$ \\
\hline ctrl & $\begin{array}{l}\text { ref|Danio rerio chymotrypsin-like (ctrl), } \\
\text { mRNA [NM_001004582] }\end{array}$ & -1.53 & $1.75 \mathrm{E}-03$ \\
\hline odam & $\begin{array}{l}\text { ref|Danio rerio odontogenic, ameloblast } \\
\text { associated (odam), mRNA } \\
\text { [NM_001145243] }\end{array}$ & -1.53 & $1.11 \mathrm{E}-03$ \\
\hline $\operatorname{trpv6}$ & $\begin{array}{l}\text { ref|Danio rerio transient receptor potential } \\
\text { cation channel, subfamily V, member } 6 \\
\text { (trpv6), mRNA [NM_001001849] }\end{array}$ & -1.54 & $1.12 \mathrm{E}-13$ \\
\hline si:dkey-269i1.4 & $\begin{array}{l}\text { ref|Danio rerio si:dkey-269i1.4 (si:dkey- } \\
\text { 269i1.4), mRNA [NM_001105680] }\end{array}$ & -1.59 & $3.28 \mathrm{E}-04$ \\
\hline si:dkey-269i1.4 & $\begin{array}{l}\text { ref|Danio rerio si:dkey-269i1.4 (si:dkey- } \\
\text { 269i1.4), mRNA [NM_001105680] }\end{array}$ & -1.62 & $2.61 \mathrm{E}-04$ \\
\hline prss59.1 & $\begin{array}{l}\text { ref|Danio rerio serine protease 59, tandem } \\
\text { duplicate } 1 \text { (prss59.1), mRNA } \\
{[\text { NM_199605] }}\end{array}$ & -1.64 & $2.15 \mathrm{E}-04$ \\
\hline he1.2 & $\begin{array}{l}\text { ref|Danio rerio hatching enzyme } 1, \\
\text { tandem dupliate } 2 \text { (he1.2), mRNA } \\
\text { [NM_213635] }\end{array}$ & -1.65 & $5.79 \mathrm{E}-04$ \\
\hline zgc:174154 & $\begin{array}{l}\text { ref|Danio rerio si:dkey-269i1.3 (si:dkey- } \\
\text { 269i1.3), mRNA [NM_001327979] }\end{array}$ & -1.66 & $4.83 \mathrm{E}-04$ \\
\hline$z g c: 92041$ & $\begin{array}{l}\text { ref|Danio rerio zgc:92041 (zgc:92041), } \\
\text { mRNA [NM_001003737] }\end{array}$ & -1.67 & $1.31 \mathrm{E}-05$ \\
\hline he1.2 & $\begin{array}{l}\text { ref|Danio rerio hatching enzyme 1, } \\
\text { tandem dupliate } 2 \text { (he1.2), mRNA } \\
\text { [NM_213635] }\end{array}$ & -1.72 & $3.37 \mathrm{E}-04$ \\
\hline si:dkey-269i1.4 & $\begin{array}{l}\text { ref|Danio rerio si:dkey-269i1.4 (si:dkey- } \\
\text { 269i1.4), mRNA [NM_001105680] }\end{array}$ & -1.73 & 3.73E-04 \\
\hline si:dkey-239j18.2 & $\begin{array}{l}\text { ref|Danio rerio si:dkey-239j18.2 (si:dkey- } \\
\text { 239j18.2), mRNA [NM_001287203] }\end{array}$ & -1.77 & $1.53 \mathrm{E}-04$ \\
\hline rps 15a & $\begin{array}{l}\text { ref|Danio rerio ribosomal protein S15a } \\
\text { (rps15a), mRNA [NM_212762] }\end{array}$ & -1.77 & $1.47 \mathrm{E}-03$ \\
\hline he1.2 & $\begin{array}{l}\text { ref|Danio rerio hatching enzyme } 1, \\
\text { tandem dupliate } 2 \text { (he1.2), mRNA } \\
{\left[N M \_213635\right]}\end{array}$ & -1.78 & $5.90 E-04$ \\
\hline he1.1 & $\begin{array}{l}\text { ref } \mid \text { Danio rerio hatching enzyme } 1 \\
\text { tandem duplicate } 1 \text { (he1.1), mRNA } \\
{\left[N M \_001045174\right]}\end{array}$ & -1.79 & $3.56 E-04$ \\
\hline MGC174155 & $\begin{array}{l}\text { ref|Danio rerio Cathepsin L1-like } \\
(M G C 174155), \text { mRNA [NM_O01103118] }\end{array}$ & -1.79 & $6.48 E-04$ \\
\hline MGC174155 & $\begin{array}{l}\text { ref|Danio rerio Cathepsin LI-like } \\
(M G C 174155), \text { mRNA [NM_001103118] }\end{array}$ & -1.80 & $4.06 E-04$ \\
\hline zgc:174154 & $\begin{array}{l}\text { ref|Danio rerio si:dkey-269i1.3 (si:dkey- } \\
\text { 269i1.3), mRNA [NM_001327979] }\end{array}$ & -1.80 & $2.12 E-04$ \\
\hline
\end{tabular}


ref|Danio rerio si:dkey-269i1.3 (si:dkey-

\begin{tabular}{|c|c|c|c|}
\hline zgc:174154 & 269i1.3), mRNA [NM_001327979] & -1.82 & $3.04 E-04$ \\
\hline zgc:92041 & $\begin{array}{l}\text { ref|Danio rerio zgc:92041 (zgc:92041), } \\
m R N A\left[N M \_001003737\right]\end{array}$ & -1.83 & $2.69 E-05$ \\
\hline A_15_P685296 & Unknown & -1.86 & $2.06 E-04$ \\
\hline MGC174155 & $\begin{array}{l}\text { ref|Danio rerio Cathepsin L1-like } \\
(M G C 174155), \text { mRNA [NM_001103118] }\end{array}$ & -1.86 & $1.44 E-04$ \\
\hline TC387424 & $\begin{array}{l}\text { tc|Rep: } M G C 174857 \text { protein - Danio } \\
\text { rerio (Zebrafish) (Brachydanio rerio), } \\
\text { complete [TC } 387424]\end{array}$ & -1.90 & $1.66 E-05$ \\
\hline MGC174155 & $\begin{array}{l}\text { ref|Danio rerio Cathepsin L1-like } \\
(M G C 174155), \text { mRNA [NM_001103118] }\end{array}$ & -1.91 & $1.47 E-04$ \\
\hline MGC174155 & $\begin{array}{l}\text { ref|Danio rerio Cathepsin L1-like } \\
(M G C 174155), \text { mRNA [NM_001103118] }\end{array}$ & -1.93 & $9.98 E-05$ \\
\hline si:dkey-269i1.4 & $\begin{array}{l}\text { ref|Danio rerio si:dkey-269i1.4 (si:dkey- } \\
\text { 269i1.4), mRNA [NM_001105680] }\end{array}$ & -1.97 & $1.87 E-04$ \\
\hline$z g c: 174153$ & $\begin{array}{l}\text { ref|Danio rerio zgc:174153 (zgc: } 174153) \text {, } \\
m R N A\left[N M \_001111192\right]\end{array}$ & -2.11 & $1.65 E-05$ \\
\hline prss59.2 & $\begin{array}{l}\text { ref } \mid \text { Danio rerio serine protease } 59, \\
\text { tandem duplicate } 2 \text { (prss59.2), mRNA } \\
{\left[N M \_001281994\right]}\end{array}$ & -2.25 & $1.61 E-04$ \\
\hline$c a 15 b$ & $\begin{array}{l}\text { ref|Danio rerio carbonic anhydrase } X V b \\
\text { (cal5b), } m R N A\left[N M \_213182\right]\end{array}$ & -2.29 & $2.44 E-03$ \\
\hline smtlb & $\begin{array}{l}\text { ref|Danio rerio somatolactin beta (smtlb), } \\
m R N A\left[N M \_001037674\right]\end{array}$ & -2.97 & $2.02 E-09$ \\
\hline
\end{tabular}




\section{Table S4.}

Differentially induced genes upon $4 \mathrm{~h}$ larval exposure to 1 -HP $(5 \mu \mathrm{M})$, in the presence or absence of CH223191 $(5 \mu \mathrm{M})$.

\begin{tabular}{|c|c|c|c|c|c|}
\hline \multirow[b]{2}{*}{$\begin{array}{l}\text { Sequence } \\
\text { Name(s) }\end{array}$} & \multirow[b]{2}{*}{ Sequence Description } & \multicolumn{2}{|c|}{ 1-HP vs DMSO } & \multicolumn{2}{|c|}{$\begin{array}{l}\text { 1-HP + CH223191 } \\
\text { vs DMSO }\end{array}$} \\
\hline & & q-value & $\begin{array}{l}\text { Log2 } \\
\text { Fold } \\
\text { Change }\end{array}$ & q-value & $\begin{array}{l}\text { Log2 } \\
\text { Fold } \\
\text { Change }\end{array}$ \\
\hline ahrra & $\begin{array}{l}\text { ref|Danio rerio aryl-hydrocarbon } \\
\text { receptor repressor a (ahrra), } \\
\text { mRNA [NM_001035265] }\end{array}$ & $3.55 \mathrm{E}-13$ & 2.56 & 9.38E-01 & 0.22 \\
\hline cyp1a & $\begin{array}{l}\text { ref|Danio rerio cytochrome P450, } \\
\text { family } 1 \text {, subfamily A (cyp1a), } \\
\text { mRNA [NM_131879] }\end{array}$ & $3.65 \mathrm{E}-20$ & 6.11 & $1.09 \mathrm{E}-01$ & 1.27 \\
\hline cyp1a & $\begin{array}{l}\text { ref|Danio rerio cytochrome } \mathrm{P} 450 \text {, } \\
\text { family } 1 \text {, subfamily A (cyp1a), } \\
\text { mRNA [NM_131879] }\end{array}$ & $9.42 \mathrm{E}-15$ & 3.93 & $8.42 \mathrm{E}-01$ & 0.47 \\
\hline cyp1a & $\begin{array}{l}\text { ref|Danio rerio cytochrome } \mathrm{P} 450 \text {, } \\
\text { family } 1 \text {, subfamily A (cyp1a), } \\
\text { mRNA [NM_131879] }\end{array}$ & $1.33 \mathrm{E}-14$ & 3.38 & $9.46 \mathrm{E}-01$ & 0.23 \\
\hline cyp1b1 & $\begin{array}{l}\text { ref|Danio rerio cytochrome } \mathrm{P} 450 \text {, } \\
\text { family } 1 \text {, subfamily } \mathrm{B}, \\
\text { polypeptide } 1 \text { (cyp } 1 \mathrm{~b} 1) \text {, transcript } \\
\text { variant } 3, \text { mRNA } \\
\text { [NM_001145708] }\end{array}$ & $4.41 \mathrm{E}-02$ & 0.90 & $9.78 \mathrm{E}-01$ & -0.11 \\
\hline cyp1c1 & $\begin{array}{l}\text { ref|Danio rerio cytochrome P450, } \\
\text { family } 1 \text {, subfamily C, } \\
\text { polypeptide } 1(\text { cyp } 1 \mathrm{c} 1), \text { mRNA } \\
\text { [NM_001020610] }\end{array}$ & $8.89 \mathrm{E}-10$ & 2.16 & $9.51 \mathrm{E}-01$ & 0.20 \\
\hline cyp1c1 & $\begin{array}{l}\text { ref|Danio rerio cytochrome P450, } \\
\text { family } 1 \text {, subfamily C, } \\
\text { polypeptide } 1(\text { cyp } 1 \mathrm{c} 1), \text { mRNA } \\
{[\mathrm{NM} 001020610]}\end{array}$ & $1.96 \mathrm{E}-11$ & 2.41 & $9.86 \mathrm{E}-01$ & 0.08 \\
\hline cyp1c2 & $\begin{array}{l}\text { ref|Danio rerio cytochrome P450, } \\
\text { family } 1 \text {, subfamily C, } \\
\text { polypeptide } 2 \text { (cyp1c2), mRNA } \\
\text { [NM_001114849] }\end{array}$ & $2.39 \mathrm{E}-07$ & 1.70 & $9.77 \mathrm{E}-01$ & -0.11 \\
\hline dhrs13l1 & $\begin{array}{l}\text { ref|Danio rerio } \\
\text { dehydrogenase/reductase (SDR } \\
\text { family) member } 13 \text { like } 1 \\
\text { (dhrs1311), mRNA [NM_205648] }\end{array}$ & $2.62 \mathrm{E}-02$ & 0.83 & $7.13 \mathrm{E}-01$ & 0.66 \\
\hline ncam3 & $\begin{array}{l}\text { ens|neural cell adhesion molecule } \\
3 \text { [Source:ZFIN;Acc:ZDB- } \\
\text { GENE-131127-340] } \\
\text { [ENSDART00000156921] }\end{array}$ & $2.03 \mathrm{E}-05$ & 0.75 & $7.80 \mathrm{E}-01$ & 0.26 \\
\hline
\end{tabular}




\begin{tabular}{|c|c|c|c|c|c|}
\hline ncam3 & $\begin{array}{l}\text { ens|neural cell adhesion molecule } \\
3 \text { [Source:ZFIN;Acc:ZDB- } \\
\text { GENE-131127-340] } \\
\text { [ENSDART00000156921] }\end{array}$ & 2.62E-02 & 1.10 & $9.88 \mathrm{E}-01$ & -0.08 \\
\hline$n f e 2 l 2 b$ & $\begin{array}{l}\text { ens|nuclear factor, erythroid 2- } \\
\text { like 2b [Source:ZFIN;Acc:ZDB- } \\
\text { GENE-120320-3] } \\
\text { [ENSDART00000122221] }\end{array}$ & $3.73 \mathrm{E}-02$ & 0.95 & $9.55 \mathrm{E}-01$ & 0.18 \\
\hline ocstamp & $\begin{array}{l}\text { ref|Danio rerio osteoclast } \\
\text { stimulatory transmembrane } \\
\text { protein (ocstamp), mRNA } \\
{\left[\mathrm{NM} \_001014340\right]}\end{array}$ & $2.23 \mathrm{E}-04$ & 1.32 & $1.76 \mathrm{E}-02$ & 1.19 \\
\hline sult6b1 & $\begin{array}{l}\text { ref|Danio rerio sulfotransferase } \\
\text { family, cytosolic, 6b, member } 1 \\
\text { (sult6b1), mRNA [NM_214686] }\end{array}$ & $1.68 \mathrm{E}-05$ & 1.26 & $9.40 \mathrm{E}-01$ & 0.19 \\
\hline sult6b1 & $\begin{array}{l}\text { ref|Danio rerio sulfotransferase } \\
\text { family, cytosolic, 6b, member } 1 \\
\text { (sult6b1), mRNA [NM_214686] }\end{array}$ & $4.94 \mathrm{E}-03$ & 1.17 & $8.49 \mathrm{E}-01$ & 0.38 \\
\hline
\end{tabular}

Table S5.

Differentially induced genes upon $4 \mathrm{~h}$ larval exposure to 1-HP $(5 \mu \mathrm{M})$, in the presence or absence of 3-o-C12-L-HSL $(50 \mu \mathrm{M}))$.

\begin{tabular}{|c|c|c|c|c|c|}
\hline & & 1-HP vs I & ISO & $\begin{array}{l}\text { 1-HP+ 3- } \\
\text { HSL vs D }\end{array}$ & $\begin{array}{l}\text { C12-L- } \\
\text { ISO }\end{array}$ \\
\hline $\begin{array}{l}\text { Sequence } \\
\text { Name(s) }\end{array}$ & Sequence Description & q-value & $\begin{array}{l}\text { Log2 } \\
\text { Fold } \\
\text { Change }\end{array}$ & q-value & $\begin{array}{l}\text { Log2 } \\
\text { Fold } \\
\text { Change }\end{array}$ \\
\hline cypla & $\begin{array}{l}\text { ref|Danio rerio cytochrome P450, } \\
\text { family } 1 \text {, subfamily A (cyp1a), } \\
\text { mRNA [NM_131879] }\end{array}$ & $3.65 \mathrm{E}-20$ & 6.11 & $5.73 \mathrm{E}-16$ & 4.63 \\
\hline cyp1a & $\begin{array}{l}\text { ref|Danio rerio cytochrome P450, } \\
\text { family } 1 \text {, subfamily A (cyp1a), } \\
\text { mRNA [NM_131879] }\end{array}$ & $9.42 \mathrm{E}-15$ & 3.93 & $1.18 \mathrm{E}-09$ & 2.71 \\
\hline cyp1a & $\begin{array}{l}\text { ref|Danio rerio cytochrome P450, } \\
\text { family } 1 \text {, subfamily A (cyp1a), } \\
\text { mRNA [NM_131879] }\end{array}$ & $1.33 \mathrm{E}-14$ & 3.38 & $1.87 \mathrm{E}-08$ & 2.14 \\
\hline ahrra & $\begin{array}{l}\text { ref|Danio rerio aryl-hydrocarbon } \\
\text { receptor repressor a (ahrra), } \\
\text { mRNA [NM_001035265] }\end{array}$ & $3.55 \mathrm{E}-13$ & 2.56 & $1.95 \mathrm{E}-06$ & 1.45 \\
\hline cyp1c1 & $\begin{array}{l}\text { ref|Danio rerio cytochrome P450, } \\
\text { family } 1 \text {, subfamily C, } \\
\text { polypeptide } 1 \text { (cyp1c1), mRNA } \\
{[\mathrm{NM} 001020610]}\end{array}$ & $1.96 \mathrm{E}-11$ & 2.41 & $4.38 \mathrm{E}-05$ & 1.34 \\
\hline cyp1c1 & $\begin{array}{l}\text { ref|Danio rerio cytochrome } \mathrm{P} 450 \text {, } \\
\text { family } 1 \text {, subfamily } \mathrm{C} \text {, }\end{array}$ & $8.89 \mathrm{E}-10$ & 2.16 & $2.21 \mathrm{E}-04$ & 1.23 \\
\hline
\end{tabular}


polypeptide 1 (cyp1c1), mRNA

[NM_001020610]

\begin{tabular}{|c|c|c|c|c|c|}
\hline cyp1c2 & $\begin{array}{l}\text { ref|Danio rerio cytochrome P450, } \\
\text { family } 1 \text {, subfamily C, } \\
\text { polypeptide } 2 \text { (cyp1c2), mRNA } \\
{[\mathrm{NM} 001114849]}\end{array}$ & $2.39 \mathrm{E}-07$ & 1.70 & $2.25 \mathrm{E}-03$ & 1.02 \\
\hline ocstamp & $\begin{array}{l}\text { ref|Danio rerio osteoclast } \\
\text { stimulatory transmembrane } \\
\text { protein (ocstamp), mRNA } \\
{[\text { NM_001014340] }}\end{array}$ & $2.23 \mathrm{E}-04$ & 1.32 & $6.83 \mathrm{E}-08$ & 1.89 \\
\hline sult6b1 & $\begin{array}{l}\text { ref|Danio rerio sulfotransferase } \\
\text { family, cytosolic, } 6 \mathrm{~b}, \text { member } 1 \\
\text { (sult6b1), mRNA [NM_214686] }\end{array}$ & 1.68E-05 & 1.26 & 7.62E-03 & 0.81 \\
\hline sult6b1 & $\begin{array}{l}\text { ref|Danio rerio sulfotransferase } \\
\text { family, cytosolic, } 6 \mathrm{~b}, \text { member } 1 \\
(\text { sult6b1), mRNA [NM_214686] }\end{array}$ & $4.94 \mathrm{E}-03$ & 1.17 & $9.25 \mathrm{E}-03$ & 0.99 \\
\hline ncam3 & $\begin{array}{l}\text { ens|neural cell adhesion molecule } \\
3 \text { [Source:ZFIN;Acc:ZDB- } \\
\text { GENE-131127-340] } \\
\text { [ENSDART00000156921] }\end{array}$ & $2.62 \mathrm{E}-02$ & 1.10 & $2.01 \mathrm{E}-02$ & 0.95 \\
\hline$n f e 2 l 2 b$ & $\begin{array}{l}\text { ens|nuclear factor, erythroid 2- } \\
\text { like 2b [Source:ZFIN;Acc:ZDB- } \\
\text { GENE-120320-3] } \\
\text { [ENSDART00000122221] }\end{array}$ & $3.73 \mathrm{E}-02$ & 0.95 & $3.71 \mathrm{E}-05$ & 1.37 \\
\hline cyp1b1 & $\begin{array}{l}\text { ref|Danio rerio cytochrome P450, } \\
\text { family } 1 \text {, subfamily B, } \\
\text { polypeptide } 1 \text { (cyp1b1), transcript } \\
\text { variant } 3, \text { mRNA } \\
\text { [NM_001145708] }\end{array}$ & $4.41 \mathrm{E}-02$ & 0.90 & 6.99E-01 & 0.27 \\
\hline dhrs13l1 & $\begin{array}{l}\text { ref|Danio rerio } \\
\text { dehydrogenase/reductase (SDR } \\
\text { family) member } 13 \text { like } 1 \\
\text { (dhrs1311), mRNA [NM_205648] }\end{array}$ & $2.62 \mathrm{E}-02$ & 0.83 & $1.57 \mathrm{E}-04$ & 1.06 \\
\hline ncam3 & $\begin{array}{l}\text { ens|neural cell adhesion molecule } \\
3 \text { [Source:ZFIN;Acc:ZDB- } \\
\text { GENE-131127-340] } \\
\text { [ENSDART00000156921] }\end{array}$ & $2.03 \mathrm{E}-05$ & 0.75 & $1.08 \mathrm{E}-04$ & 0.67 \\
\hline
\end{tabular}


Table S6.

CRISPR sequences used in this study.

\begin{tabular}{lccc}
\hline \multicolumn{1}{c}{ Target Gene } & Vector & CRISPR sequence & Source \\
\hline AhR & pLv-U6g-EPCG & AGTCGGTCTCTATGCCGCTTGG & $\begin{array}{c}\text { Sigma- } \\
\text { Aldrich }\end{array}$ \\
\hline Scramble Control & pLv-U6g-EPCG & & Sigma- \\
& & & Aldrich \\
\hline
\end{tabular}


Table S7.

List of molecules used in this study.

\begin{tabular}{|c|c|c|c|c|}
\hline Name & $\begin{array}{c}\text { Abbreviation } \\
\text { name }\end{array}$ & Source & Reference & Storage \\
\hline $\begin{array}{l}\text { 2,3,7,8-Tetrachlorodibenzo-p- } \\
\text { dioxin }\left[{ }^{3} \mathbf{H}(G)\right]\end{array}$ & {$\left[{ }^{3} \mathrm{H}\right] \mathrm{TCDD}$} & $\begin{array}{l}\text { Hartmann } \\
\text { Analytical }\end{array}$ & ART1642 & $-20^{\circ} \mathrm{C}$ \\
\hline 1-Hydroxyphenazine & $1-\mathrm{HP}$ & $\begin{array}{l}\text { TCI } \\
\text { chemicals }\end{array}$ & H0289 & RT \\
\hline $\begin{array}{l}\text { N-6-Cyclohexyl-3-oxohexanoyl- } \\
\text { L-homoserinelactone }\end{array}$ & $\begin{array}{l}\text { 3-o-6-Cy-C6- } \\
\text { L-HSL }\end{array}$ & $\begin{array}{l}\text { University of } \\
\text { Nottingham }\end{array}$ & 39 & $-20^{\circ} \mathrm{C}$ \\
\hline $\begin{array}{l}\text { N-6-Phenyl-3-oxohexanoyl-L- } \\
\text { homoserinelactone }\end{array}$ & $\begin{array}{l}\text { 3-o-6-Ph-C6- } \\
\text { L-HSL }\end{array}$ & $\begin{array}{l}\text { University of } \\
\text { Nottingham }\end{array}$ & 40 & $-20^{\circ} \mathrm{C}$ \\
\hline $\begin{array}{l}\text { 3-3-Oxododecanoylamin)-L-2- } \\
\text { pyrrolidone }\end{array}$ & 3-o-C12-L-AP & $\begin{array}{l}\text { University of } \\
\text { Nottingham }\end{array}$ & 37 & $-20^{\circ} \mathrm{C}$ \\
\hline $\begin{array}{l}\text { 2-3-Oxododecanoylamino- } \\
\text { thiazole }\end{array}$ & 3-o-C12-L-AT & $\begin{array}{l}\text { University of } \\
\text { Nottingham }\end{array}$ & 38 & $-20^{\circ} \mathrm{C}$ \\
\hline $\begin{array}{l}\text { N-3-Oxododecanoyl-L- } \\
\text { homoserinelactone }\end{array}$ & $\begin{array}{l}\text { 3-o-C12-L- } \\
\text { HSL }\end{array}$ & Biomol & Cay10007895 & $-20^{\circ} \mathrm{C}$ \\
\hline $\begin{array}{l}\text { N-3-Oxododecanoyl-L- } \\
\text { homocysteinethiolactone }\end{array}$ & $\begin{array}{l}\text { 3-o-C12-L- } \\
\text { HTL }\end{array}$ & $\begin{array}{l}\text { University of } \\
\text { Nottingham }\end{array}$ & 36 & $-20^{\circ} \mathrm{C}$ \\
\hline $\begin{array}{l}\text { N-3-Oxotetradecanoyl-L- } \\
\text { homoserinelactone }\end{array}$ & $\begin{array}{l}\text { 3-o-C14-L- } \\
\text { HSL }\end{array}$ & $\begin{array}{l}\text { Sigma- } \\
\text { Aldrich }\end{array}$ & O9264 & $-20^{\circ} \mathrm{C}$ \\
\hline $\begin{array}{l}\text { N-3-Oxo-hexadec-11(Z)-enoyl-L- } \\
\text { homoserine lactone }\end{array}$ & $\begin{array}{l}\text { 3-o-C16:1- } \\
\Delta 11 \text {-cis-L- } \\
\text { HSL }\end{array}$ & Biomol & Cay10011238 & $-20^{\circ} \mathrm{C}$ \\
\hline $\begin{array}{l}\text { N-3-Oxohexanoyl-L- } \\
\text { homoserinelactone }\end{array}$ & 3-o-C6-L-HSL & $\begin{array}{l}\text { Sigma- } \\
\text { Aldrich }\end{array}$ & K3007 & $-20^{\circ} \mathrm{C}$ \\
\hline $\begin{array}{l}\text { N-3-Oxooctanoyl-L- } \\
\text { homoserinelactone }\end{array}$ & 3-o-C8-L-HSL & Biomol & Cay10011206 & $-20^{\circ} \mathrm{C}$ \\
\hline $\begin{array}{l}\text { N-3-Hydroxydecanoyl-L- } \\
\text { homoserinelactone }\end{array}$ & $\begin{array}{l}\text { 3-OH-C10-L- } \\
\text { HSL }\end{array}$ & Biomol & Cay9001147 & $-20^{\circ} \mathrm{C}$ \\
\hline $\begin{array}{l}\text { N-3-Hydroxydodecanoyl-DL- } \\
\text { homoserinelactone }\end{array}$ & $\begin{array}{l}\text { 3-OH-C12- } \\
\text { DL-HSL }\end{array}$ & $\begin{array}{l}\text { Sigma- } \\
\text { Aldrich }\end{array}$ & 53727 & $-20^{\circ} \mathrm{C}$ \\
\hline $\begin{array}{l}\text { N-3-Hydroxytridecanoyl-L- } \\
\text { homoserinelactone }\end{array}$ & $\begin{array}{l}\text { 3-OH-C13-L- } \\
\text { HSL }\end{array}$ & $\begin{array}{l}\text { University of } \\
\text { Nottingham }\end{array}$ & 23 & $-20^{\circ} \mathrm{C}$ \\
\hline $\begin{array}{l}\text { N-3-Hydroxytetradecanoyl-DL- } \\
\text { homoserinelactone }\end{array}$ & $\begin{array}{l}\text { 3-OH-C14- } \\
\text { DL-HSL }\end{array}$ & $\begin{array}{l}\text { Sigma- } \\
\text { Aldrich }\end{array}$ & 51481 & $-20^{\circ} \mathrm{C}$ \\
\hline $\begin{array}{l}\text { N-3-Hydroxyhexadecanoyl-L- } \\
\text { homoserinelactone }\end{array}$ & $\begin{array}{l}\text { 3-OH-C16-L- } \\
\text { HSL }\end{array}$ & $\begin{array}{l}\text { University of } \\
\text { Nottingham }\end{array}$ & 28 & $-20^{\circ} \mathrm{C}$ \\
\hline $\begin{array}{l}\text { N-3-Hydroxyoctadecanoyl-L- } \\
\text { homoserinelactone }\end{array}$ & $\begin{array}{l}\text { 3-OH-C18-L- } \\
\text { HSL }\end{array}$ & $\begin{array}{l}\text { University of } \\
\text { Nottingham }\end{array}$ & 32 & $-20^{\circ} \mathrm{C}$ \\
\hline $\begin{array}{l}\text { N-3-Hydroxyoctanoyl-L- } \\
\text { homoserinelactone }\end{array}$ & $\begin{array}{l}\text { 3-OH-C8-L- } \\
\text { HSL }\end{array}$ & Biomol & Cay9001150 & $-20^{\circ} \mathrm{C}$ \\
\hline $\begin{array}{l}\text { N-Decanoyl-L- } \\
\text { homoserinelactone }\end{array}$ & C10-L-HSL & Biomol & Cay10011201 & $-20^{\circ} \mathrm{C}$ \\
\hline
\end{tabular}




\begin{tabular}{|c|c|c|c|c|}
\hline $\begin{array}{l}\text { N-Undecanoyl-L- } \\
\text { homoserinelactone }\end{array}$ & C11-L-HSL & Biomol & Cay16827 & $-20^{\circ} \mathrm{C}$ \\
\hline $\begin{array}{l}\text { N-Dodecanoyl-L- } \\
\text { homoserinelactone }\end{array}$ & C12-L-HSL & Biomol & Cay10011203 & $-20^{\circ} \mathrm{C}$ \\
\hline $\begin{array}{l}\text { N-Tridecanoyl-L- } \\
\text { homoserinelactone }\end{array}$ & C13-L-HSL & Biomol & Cay13093 & $-20^{\circ} \mathrm{C}$ \\
\hline $\begin{array}{l}\text { N-cis-Tetradec-9Z-enoyl-L- } \\
\text { homoserinelactone }\end{array}$ & $\begin{array}{l}\text { C14:1- } \Delta 9 \text {-cis- } \\
\text { L-HSL }\end{array}$ & Biomol & Cay10012672 & $-20^{\circ} \mathrm{C}$ \\
\hline $\begin{array}{l}\text { N-Tetradecanoyl-L- } \\
\text { homoserinelactone }\end{array}$ & C14-L-HSL & Biomol & Cay10011200 & $-20^{\circ} \mathrm{C}$ \\
\hline $\begin{array}{l}\text { N-Pentadecanoyl-L- } \\
\text { homoserinelactone }\end{array}$ & C15-L-HSL & Biomol & Cay13094 & $-20^{\circ} \mathrm{C}$ \\
\hline $\begin{array}{l}\text { N-cis-Hexadec-9Z-enoyl-L- } \\
\text { homoserinelactone }\end{array}$ & $\begin{array}{l}\text { C16:1- } \Delta 9 \text {-cis- } \\
\text { L-HSL }\end{array}$ & Biomol & Cay10012673 & $-20^{\circ} \mathrm{C}$ \\
\hline $\begin{array}{l}\text { N-cis-Octadec-9-enoyl-L- } \\
\text { homoserinelactone }\end{array}$ & $\begin{array}{l}\text { C18:1- } \Delta 9 \text {-cis- } \\
\text { L-HSL }\end{array}$ & Biomol & Cay10012674 & $-20^{\circ} \mathrm{C}$ \\
\hline N-Butyryl-L-homoserinelactone & C4-L-HSL & Biomol & Cay10007898 & $-20^{\circ} \mathrm{C}$ \\
\hline $\begin{array}{l}\text { N-Butyryl-L- } \\
\text { homocysteinethiolactone }\end{array}$ & C4-L-HTL & Biomol & Cay10011204 & $-20^{\circ} \mathrm{C}$ \\
\hline $\begin{array}{l}\text { N-hexanoyl-L- } \\
\text { homoserinelactone }\end{array}$ & C6-L-HSL & Biomol & Cay10007896 & $-20^{\circ} \mathrm{C}$ \\
\hline $\begin{array}{l}\text { N-Heptanoyl-L- } \\
\text { homoserinelactone }\end{array}$ & C7-L-HSL & Biomol & Cay10011198 & $-20^{\circ} \mathrm{C}$ \\
\hline $\begin{array}{l}\text { N-Octanoyl-L- } \\
\text { homoserinelactone }\end{array}$ & C8-L-HSL & Biomol & Cay10011199 & $-20^{\circ} \mathrm{C}$ \\
\hline $\begin{array}{l}\text { N-Phenylacetyl-L- } \\
\text { homoserinelactone }\end{array}$ & $\begin{array}{l}\text { C8-L-HSL } \\
\text { ring closure }\end{array}$ & Biomol & Cay9001737 & $-20^{\circ} \mathrm{C}$ \\
\hline $\begin{array}{l}\text { N-Nonanoyl-L- } \\
\text { homoserinelactone }\end{array}$ & C9-L-HSL & Biomol & Cay16868 & $-20^{\circ} \mathrm{C}$ \\
\hline $\begin{array}{l}\text { 2-Methyl-2H-pyrazole-3- } \\
\text { carboxylic acid ( } 2 \text {-methyl-4-o- } \\
\text { tolylazo-phenyl)-amide }\end{array}$ & $\mathrm{CH} 223191$ & $\begin{array}{l}\text { Sigma- } \\
\text { Aldrich }\end{array}$ & C8124 & $4^{\circ} \mathrm{C}$ \\
\hline 2-Heptyl-4-quinolone & HHQ & $\begin{array}{l}\text { Sigma- } \\
\text { Aldrich }\end{array}$ & SML0747 & $-20^{\circ} \mathrm{C}$ \\
\hline $\begin{array}{l}\text { N-p-Coumaroyl-L-homoserine } \\
\text { lactone }\end{array}$ & $\begin{array}{l}\text { p-coumaroyl- } \\
\text { L-HSL }\end{array}$ & $\begin{array}{l}\text { Sigma- } \\
\text { Aldrich }\end{array}$ & 7077 & $-20^{\circ} \mathrm{C}$ \\
\hline $\begin{array}{l}\text { 2-Heptyl-3-hydroxy- } \\
\text { 4(1H)quinolone }\end{array}$ & PQS & $\begin{array}{l}\text { Sigma- } \\
\text { Aldrich }\end{array}$ & 94398 & $-20^{\circ} \mathrm{C}$ \\
\hline Pyocyanin & Pyo & $\begin{array}{l}\text { Sigma- } \\
\text { Aldrich }\end{array}$ & P0046 & $-20^{\circ} \mathrm{C}$ \\
\hline $\begin{array}{l}\text { 2,3,7,8-Tetrachlorodibenzo-p- } \\
\text { dioxin }\end{array}$ & TCDD & $\begin{array}{l}\text { Sigma- } \\
\text { Aldrich }\end{array}$ & 48599 & $4^{\circ} \mathrm{C}$ \\
\hline
\end{tabular}


Table S8.

List of primers and probes used in this study.

\begin{tabular}{|c|c|c|}
\hline Gene & Primer sequence & Organism \\
\hline \multirow[t]{2}{*}{$A h R R$} & F-GCGCCTCAGTGTCAGTTACC & \multirow[t]{2}{*}{ human } \\
\hline & R-CTCCTGCACGACTTGGAAGAA & \\
\hline \multirow[t]{2}{*}{ CYP1A1 } & F-ACATGCTGACCCTGGGAAAG & \multirow[t]{2}{*}{ human } \\
\hline & R-GGTGTGGAGCCAATTCGGAT & \\
\hline \multirow[t]{2}{*}{ CYP1B1 } & F-GGGACCGTCTGCCTTGTATG & \multirow[t]{2}{*}{ human } \\
\hline & R-GGTGGCATGAGGAATAGTGACA & \\
\hline \multirow[t]{2}{*}{ GAPDH } & F-CATGAGAAGTATGACAACAGCCT & \multirow[t]{2}{*}{ human } \\
\hline & R-AGTCCTTCCACGATACCAAAGT & \\
\hline \multirow[t]{2}{*}{$I L-1 b$} & F-CTCGCCAGTGAAATGATGGCT & \multirow[t]{2}{*}{ human } \\
\hline & R-GTCGGAGATTCGTAGCTGGAT & \\
\hline \multirow[t]{2}{*}{$I L-8$} & F-TTTTGCCAAGGAGTGCTAAAGA & \multirow[t]{2}{*}{ human } \\
\hline & R-AACCCTCTGCACCCAGTTTTC & \\
\hline \multirow[t]{2}{*}{ ahRRa } & F-GCCGCTGGCATATAACATGAGC & \multirow[t]{2}{*}{ zebrafish } \\
\hline & R-TGACGCTGTGTTCACGTCACTG & \\
\hline \multirow[t]{2}{*}{$a h R R b$} & F-GACTACCTGGGATTTCATCAGACG & \multirow[t]{2}{*}{ zebrafish } \\
\hline & R-GAGCCGTCACAACATCCTCATC & \\
\hline \multirow[t]{2}{*}{$\beta$-actin } & F-CGAGCAGGAGATGGGAACC & \multirow[t]{2}{*}{ zebrafish } \\
\hline & R-CAACGGAAACGCTCATTGC & \\
\hline \multirow[t]{2}{*}{ cyp1a } & F-GCATTACGATACGTTCGATAAGGAC & \multirow[t]{2}{*}{ zebrafish } \\
\hline & R-GCTCCGAATAGGTCATTGACGAT & \\
\hline \multirow[t]{2}{*}{ cyp1b1 } & F-AGGGGGTGATTTCGGATACAG & \multirow[t]{2}{*}{ zebrafish } \\
\hline & R-AAATCACAAGTGTGAACGCTCT & \\
\hline \multirow[t]{2}{*}{ cyp1c1 } & F-GGGCAAATGCCACACATCAC & \multirow[t]{2}{*}{ zebrafish } \\
\hline & R-TTCCTTATCGCCGCATCTCC & \\
\hline \multirow[t]{2}{*}{ cyp1c2 } & F-GCGCTCATTGCATCGTTCAT & \multirow[t]{2}{*}{ zebrafish } \\
\hline & R-CAAAGGGTCCCGGAAGTCTC & \\
\hline \multirow[t]{2}{*}{ dhrs $13 l 1$} & F-AGAAGCTCGGTCTGGGATCT & \multirow[t]{2}{*}{ zebrafish } \\
\hline & R-ACTGAACCTGGATGGAGACTG & \\
\hline \multirow[t]{2}{*}{ ncam3 } & F-CCCCAGTCAGTTCAGCATGT & \multirow[t]{2}{*}{ zebrafish } \\
\hline & R-AGTAGCTAATGGGGGAGCCT & \\
\hline$n f e 2 l 2 b$ & F-AGAAGCAGGGTTTCGGTGAG & zebrafish \\
\hline & R-TGGATCGGGGAGGTTAGGTT & \\
\hline sultb1 & F-AAACCCGAAAGACACGCTGG & zebrafish \\
\hline & R-CCCCAACTAACATCACCAGTCA & \\
\hline
\end{tabular}


Table S9.

List of antibodies used on this study.

\begin{tabular}{|c|c|c|c|c|c|c|}
\hline Protein & Company & Ref. & Dilution & $\begin{array}{l}\text { Incubation } \\
\text { conditions }\end{array}$ & Application & Fluorochrome \\
\hline $\begin{array}{l}\text { Human } \beta- \\
\text { actin }\end{array}$ & Abcam & $\begin{array}{l}a b 627 \\
6\end{array}$ & $1 / 24000$ & 1h, RT & WB & \\
\hline $\begin{array}{l}\text { Human } \\
\text { AhR }\end{array}$ & Santa Cruz & $\begin{array}{l}\text { sc- } \\
85682\end{array}$ & $1 / 500$ & $\begin{array}{l}\text { overnight, } \\
4^{\circ} \mathrm{C}\end{array}$ & WB & \\
\hline $\begin{array}{l}\text { IgG } \\
\text { mouse }\end{array}$ & $\begin{array}{l}\text { Cell } \\
\text { Signaling }\end{array}$ & 7076 & $1 / 5000$ & 1h, RT & WB & \\
\hline $\begin{array}{l}\text { Zebrafish } \\
\text { CYP1A }\end{array}$ & $\begin{array}{l}\text { Biosense } \\
\text { laboratories }\end{array}$ & C10-7 & $1 / 1000$ & $\begin{array}{l}\text { overnight, } \\
4^{\circ} \mathrm{C}\end{array}$ & WB & \\
\hline $\begin{array}{l}\text { Zebrafish } \\
\alpha \text {-tubulin }\end{array}$ & $\begin{array}{l}\text { Sigma- } \\
\text { Aldrich }\end{array}$ & $\begin{array}{l}\text { T619 } \\
9\end{array}$ & $1 / 1000$ & $\begin{array}{l}\text { overnight, } \\
4^{\circ} \mathrm{C}\end{array}$ & WB & \\
\hline $\begin{array}{l}\text { Mouse } \\
\text { CD45 }\end{array}$ & Biolegend & 104 & $1 / 100$ & $15 \mathrm{~min}, 4^{\circ} \mathrm{C}$ & $\begin{array}{l}\text { Flow } \\
\text { cytometry }\end{array}$ & Alexa 700 \\
\hline $\begin{array}{l}\text { Mouse } \\
\text { Siglec F }\end{array}$ & $\begin{array}{l}\text { BD } \\
\text { Pharmingen }\end{array}$ & $\begin{array}{l}\text { E50- } \\
2440\end{array}$ & $1 / 100$ & $15 \mathrm{~min}, 4^{\circ} \mathrm{C}$ & $\begin{array}{l}\text { Flow } \\
\text { cytometry }\end{array}$ & Pacific Blue \\
\hline $\begin{array}{l}\text { Mouse } \\
\text { CD11c }\end{array}$ & Biolegend & N418 & $1 / 400$ & $15 \mathrm{~min}, 4^{\circ} \mathrm{C}$ & $\begin{array}{l}\text { Flow } \\
\text { cytometry }\end{array}$ & $\mathrm{APC}$ \\
\hline $\begin{array}{l}\text { Mouse } \\
\text { Ly6G }\end{array}$ & Biolegend & $1 \mathrm{~A} 8$ & $1 / 100$ & $15 \mathrm{~min}, 4^{\circ} \mathrm{C}$ & $\begin{array}{l}\text { Flow } \\
\text { cytometry }\end{array}$ & PerCP Cy5.5 \\
\hline $\begin{array}{l}\text { Mouse } \\
\text { CD11b }\end{array}$ & $\begin{array}{l}\text { BD } \\
\text { Pharmingen }\end{array}$ & $\begin{array}{l}\mathrm{M} 1 / 7 \\
0\end{array}$ & $1 / 200$ & $15 \mathrm{~min}, 4^{\circ} \mathrm{C}$ & $\begin{array}{l}\text { Flow } \\
\text { cytometry }\end{array}$ & PeCy7 \\
\hline
\end{tabular}


Table S10.

List of bacteria used in this study.

\begin{tabular}{|c|c|c|c|c|}
\hline Target Gene & $\begin{array}{c}\text { Medium } \\
\text { used }\end{array}$ & $\begin{array}{c}\text { Antibiotic } \\
\text { used }\end{array}$ & Source & References \\
\hline PA14 WT & LB & & $\begin{array}{l}\text { Burkhard Tuemmler } \\
\text { (Medizinsche Hoschule } \\
\text { Hannover, Germany) }\end{array}$ & 10 \\
\hline PA14 WT-GFP & LB & $\begin{array}{l}\text { Carbenicillin } \\
300 \mu \mathrm{g} / \mathrm{mL}\end{array}$ & $\begin{array}{l}\text { Fred Ausubel (Harvard } \\
\text { Medical } \\
\text { School/Massachussets } \\
\text { General Hospital, Boston, } \\
\text { USA) }\end{array}$ & 85 \\
\hline PA14 09480 & LB & & $\begin{array}{l}\text { Burkhard Tuemmler } \\
\text { (Medizinsche Hoschule } \\
\text { Hannover, Germany) }\end{array}$ & 10 \\
\hline PA14 $\Delta r s a L$ & LB & & $\begin{array}{l}\text { Livia Leoni (University } \\
\text { Roma Tre, Rome, Italy) }\end{array}$ & 27,41 \\
\hline PA14 R3 & LB & & $\begin{array}{l}\text { Livia Leoni (University } \\
\text { Roma Tre, Rome, Italy) }\end{array}$ & 27 \\
\hline PAO1 & LB & & $\begin{array}{l}\text { Burkhard Tuemmler } \\
\text { (Medizinsche Hoschule } \\
\text { Hannover, Germany) }\end{array}$ & 10 \\
\hline $\begin{array}{l}\text { PAO1 pqsA CTX- } \\
\text { lux::pqsA }\end{array}$ & $\mathrm{LB}$ & $\begin{array}{l}\text { Tetracycline } \\
125 \mu \mathrm{g} / \mathrm{mL}\end{array}$ & $\begin{array}{l}\text { Paul Williams (University of } \\
\text { Nottingham, Nottingham, } \\
\text { UK) }\end{array}$ & 28 \\
\hline
\end{tabular}


Table S11.

Custom gene set used for xenobiotic metabolism gene enrichment analysis.

\begin{tabular}{|c|c|}
\hline ZFIN ID & gene name \\
\hline ZDB-GENE-030529-3 & $a d h 8 a$ \\
\hline ZDB-GENE-020531-2 & ahrla \\
\hline ZDB-GENE-050922-1 & $a h r l b$ \\
\hline ZDB-GENE-990714-16 & $a h r 2$ \\
\hline ZDB-GENE-051018-1 & ahrra \\
\hline ZDB-GENE-051018-2 & $a h r r b$ \\
\hline ZDB-GENE-030131-9732 & apobb.1 \\
\hline ZDB-GENE-060126-7 & arnt \\
\hline ZDB-GENE-050522-215 & atp6v0alb \\
\hline ZDB-GENE-031219-5 & $c a 2$ \\
\hline ZDB-GENE-011210-1 & casp3a \\
\hline ZDB-GENE-020530-2 & $\operatorname{cox} 2 a$ \\
\hline ZDB-GENE-041014-323 & $\operatorname{cox} 2 b$ \\
\hline ZDB-GENE-030131-1132 & $c p b 1$ \\
\hline ZDB-GENE-040426-2148 & $c y b 5 a$ \\
\hline ZDB-GENE-990415-43 & cyp19ala \\
\hline ZDB-GENE-001103-4 & cyp19a1b \\
\hline ZDB-GENE-011219-1 & cypla \\
\hline ZDB-GENE-030902-1 & cyp1b1 \\
\hline ZDB-GENE-050522-501 & cyplcl \\
\hline ZDB-GENE-050705-1 & cyplc2 \\
\hline ZDB-GENE-050604-1 & cyp3a65 \\
\hline ZDB-GENE-030131-5128 & $e e f 2 b$ \\
\hline ZDB-GENE-020806-5 & esrl \\
\hline ZDB-GENE-070424-74 & foxqla \\
\hline ZDB-GENE-030131-9854 & grhl3 \\
\hline ZDB-GENE-020806-4 & gstpl \\
\hline ZDB-GENE-061207-54 & hipk3a \\
\hline ZDB-GENE-030131-3102 & hmoxla \\
\hline ZDB-GENE-990415-91 & hsp70.1 \\
\hline ZDB-GENE-050309-169 & im:7150988 \\
\hline ZDB-GENE-030131-556 & keapla \\
\hline ZDB-GENE-080508-1 & keaplb \\
\hline ZDB-GENE-060316-2 & $k r t 1-11 b$ \\
\hline ZDB-GENE-040711-2 & ncehla \\
\hline ZDB-GENE-061110-43 & nceh1b.1 \\
\hline ZDB-GENE-030723-2 & $n f e 2 l 2 a$ \\
\hline ZDB-GENE-030131-1226 & nqol \\
\hline
\end{tabular}




\begin{tabular}{ll}
\hline ZDB-GENE-031006-8 & $n t 5 c 2 l 1$ \\
\hline ZDB-GENE-030131-12 & si:ch $211-$ \\
& $117 m 20.5$ \\
\hline ZDB-GENE-051014-1 & smpd $a$ \\
\hline ZDB-GENE-990415-258 & sod 1 \\
\hline ZDB-GENE-030131-7447 & sort $l b$ \\
\hline ZDB-GENE-030131-2144 & sult 1 st 1 \\
\hline ZDB-GENE-030804-27 & sult 1 st 2 \\
\hline ZDB-GENE-030804-28 & sult 1 st 3 \\
\hline ZDB-GENE-050809-2 & sult $1 s t 5$ \\
\hline ZDB-GENE-050417-228 & sult $6 b 1$ \\
\hline ZDB-GENE-030131-73 & tgfbi \\
\hline ZDB-GENE-031002-47 & tiparp \\
\hline ZDB-GENE-040718-150 & ufd $1 l$ \\
\hline ZDB-GENE-100113-1 & unm_it 275 \\
\hline ZDB-GENE-001201-1 & vtgl \\
\hline ZDB-GENE-031010-24 & zgc: 77439 \\
\hline ZDB-GENE-030131-1107 & zgc: 77849 \\
\hline
\end{tabular}




\section{References and Notes:}

55. M. W. Pfaffl, A new mathematical model for relative quantification in real-time RT-PCR. Nucleic Acids Res 29, e45 (2001).

56. L. Lozza et al., Crosstalk between human DC subsets promotes antibacterial activity and CD8+ T-cell stimulation in response to bacille Calmette-Guerin. Eur J Immunol 44, 8092 (2014).

57. A. Mohammadi-Bardbori, Assay for quantitative determination of CYP1A1 enzyme activity using 7-Ethoxyresorufin as standard substrate (EROD assay). (2014).

58. M. E. Ritchie et al., limma powers differential expression analyses for RNA-sequencing and microarray studies. Nucleic Acids Res 43, e47 (2015).

59. J. Weiner 3rd, Domaszewska, T., tmod: an R package for general and multivariate enrichment analysis. PeerJ Preprints 4:e2420v1, (2016).

60. J. Zyla, M. Marczyk, J. Weiner, J. Polanska, Ranking metrics in gene set enrichment analysis: do they matter? BMC Bioinformatics 18, 256 (2017).

61. N. Eswar et al., Comparative protein structure modeling using Modeller. Curr Protoc Bioinformatics Chapter 5, Unit-5 6 (2006).

62. M. Y. Shen, A. Sali, Statistical potential for assessment and prediction of protein structures. Protein Sci 15, 2507-2524 (2006).

63. T. A. Halgren et al., Glide: a new approach for rapid, accurate docking and scoring. 2. Enrichment factors in database screening. J Med Chem 47, 1750-1759 (2004).

64. N. Huang et al., Crystal structure of the heterodimeric CLOCK:BMAL1 transcriptional activator complex. Science 337, 189-194 (2012).

65. C. Nüsslein-Volhard, Dahm, R., Zebrafish. C. Nüsslein-Volhard, Dahm, R., Ed., (Oxford University Press, 2002), pp. 303.

66. D. C. Nacci, L; Kuhn,A; Champlin, D; Munns, W; Specker, J; Cooper, K, Nondestructive indicator of ethoxyresorufin-O-deethylase activity in embryonic fish. ENVIRONMENTAL TOXICOLOGY AND CHEMISTRY 17, 2481-2486 (1998).

67. V. Link, A. Shevchenko, C. P. Heisenberg, Proteomics of early zebrafish embryos. BMC Dev Biol 6, 1 (2006).

68. S. Subramoni, V. Venturi, LuxR-family 'solos': bachelor sensors/regulators of signalling molecules. Microbiology 155, 1377-1385 (2009).

69. A. Neumann, D. Patzelt, I. Wagner-Dobler, S. Schulz, Identification of new Nacylhomoserine lactone signalling compounds of Dinoroseobacter shibae DFL-12(T) by overexpression of luxI genes. Chembiochem 14, 2355-2361 (2013).

70. M. Elasri et al., Acyl-homoserine lactone production is more common among plantassociated Pseudomonas spp. than among soilborne Pseudomonas spp. Appl Environ Microbiol 67, 1198-1209 (2001).

71. R. L. Ulrich et al., Role of quorum sensing in the pathogenicity of Burkholderia pseudomallei. J Med Microbiol 53, 1053-1064 (2004).

72. R. L. Ulrich, D. Deshazer, H. B. Hines, J. A. Jeddeloh, Quorum sensing: a transcriptional regulatory system involved in the pathogenicity of Burkholderia mallei. Infect Immun 72, 6589-6596 (2004). 
73. G. Brader, S. Sjoblom, H. Hyytiainen, K. Sims-Huopaniemi, E. T. Palva, Altering substrate chain length specificity of an acylhomoserine lactone synthase in bacterial communication. J Biol Chem 280, $10403-10409$ (2005).

74. A. M. Pomini, G. P. Manfio, W. L. Araujo, A. J. Marsaioli, Acyl-homoserine lactones from Erwinia psidii R. IBSBF 435T, a guava phytopathogen (Psidium guajava L.). $J$ Agric Food Chem 53, 6262-6265 (2005).

75. O. Geisenberger et al., Production of N-acyl-L-homoserine lactones by P. aeruginosa isolates from chronic lung infections associated with cystic fibrosis. FEMS Microbiol Lett 184, 273-278 (2000).

76. G. D. Geske, J. C. O'Neill, D. M. Miller, M. E. Mattmann, H. E. Blackwell, Modulation of bacterial quorum sensing with synthetic ligands: systematic evaluation of $\mathrm{N}$-acylated homoserine lactones in multiple species and new insights into their mechanisms of action. J Am Chem Soc 129, 13613-13625 (2007).

77. G. D. Geske, R. J. Wezeman, A. P. Siegel, H. E. Blackwell, Small molecule inhibitors of bacterial quorum sensing and biofilm formation. J Am Chem Soc 127, 12762-12763 (2005).

78. V. Nagar, V. Sinha, J. R. Bandekar, Diverse Profiles of N-acyl Homoserine L-Lactones, Biofilm, Virulence Genes and Integrons in Food-Borne Aeromonas Isolates. J Food Sci 80, M1861-1870 (2015).

79. A. L. Schaefer et al., A new class of homoserine lactone quorum-sensing signals. Nature 454, 595-599 (2008).

80. K. Riedel et al., N-acylhomoserine-lactone-mediated communication between Pseudomonas aeruginosa and Burkholderia cepacia in mixed biofilms. Microbiology 147, 3249-3262 (2001).

81. P. Williams, Quorum sensing, communication and cross-kingdom signalling in the bacterial world. Microbiology 153, 3923-3938 (2007).

82. J. P. Kirwan et al., Quorum-sensing signal synthesis by the Yersinia pestis acylhomoserine lactone synthase YspI. J Bacteriol 188, 784-788 (2006).

83. C. A. Ortori et al., Comprehensive profiling of $\mathrm{N}$-acylhomoserine lactones produced by Yersinia pseudotuberculosis using liquid chromatography coupled to hybrid quadrupolelinear ion trap mass spectrometry. Anal Bioanal Chem 387, 497-511 (2007).

84. A. Rajput, K. Kaur, M. Kumar, SigMol: repertoire of quorum sensing signaling molecules in prokaryotes. Nucleic Acids Res 44, D634-639 (2016).

85. M. W. Tan, S. Mahajan-Miklos, F. M. Ausubel, Killing of Caenorhabditis elegans by Pseudomonas aeruginosa used to model mammalian bacterial pathogenesis. Proc Natl Acad Sci U S A 96, 715-720 (1999).

86. E. K. Shiner et al., Pseudomonas aeruginosa autoinducer modulates host cell responses through calcium signalling. Cell Microbiol 8, 1601-1610 (2006). 